
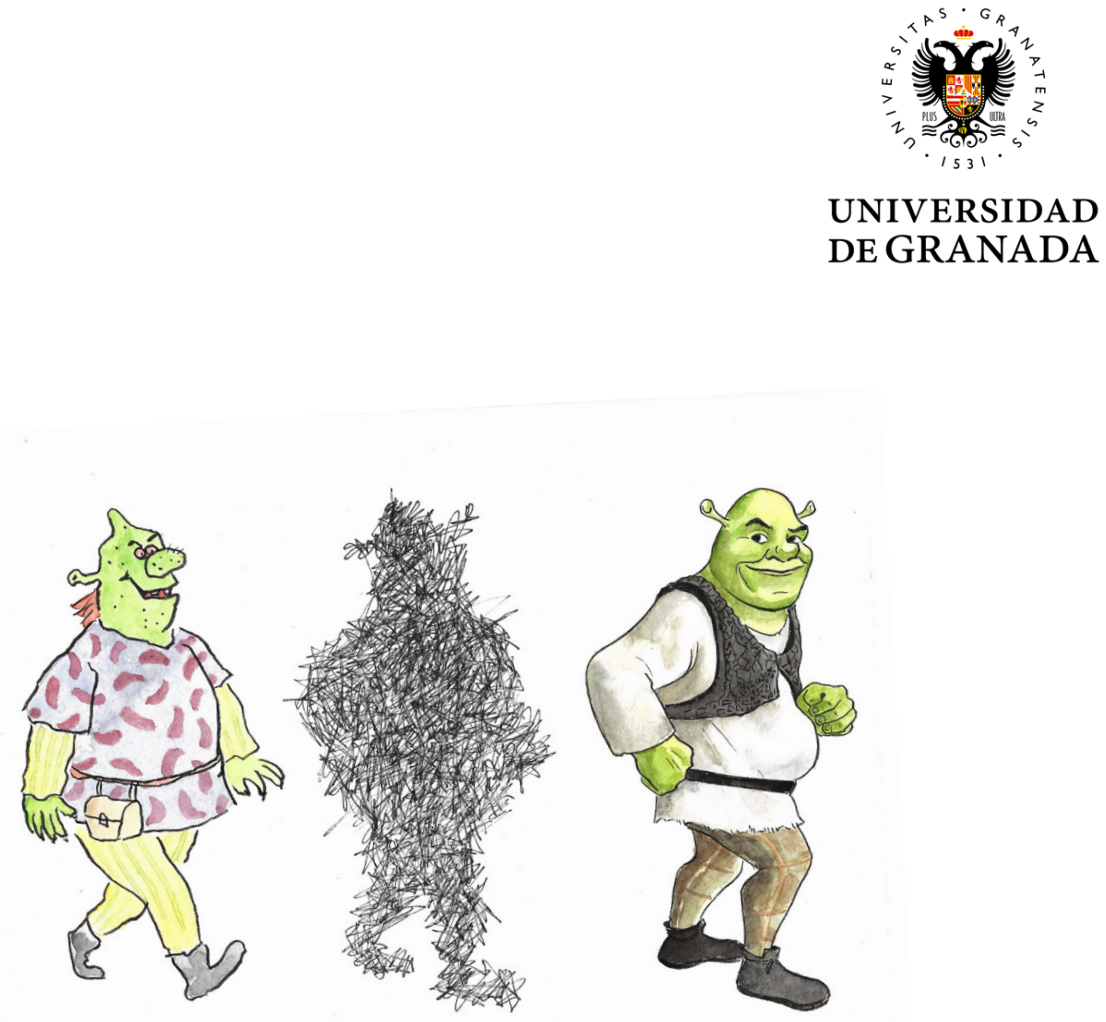

I $=$ M Trabajo Fin de Master

Máster en Dibujo: Ilustración, Cómic y Creación Audiovisual

\title{
LA ADAPTACIÓN DE ÁLBUMES \\ ILUSTRADOS INFANTILES AL MEDIO AUDIOVISUAL
}

\section{RESEARCH ON FILM ADAPTATION OF CHILDREN'S PICTURE BOOKS}

\author{
Autora: Sara Martínez Maiso \\ Tutora: $M^{a}$ Carmen Hidalgo Rodríguez \\ Ilustración infantil \\ Departamento de Dibujo
}

Febrero 2020 


\footnotetext{
7 $1 /$ Trabajo Fin de Master

Máster en Dibujo: Ilustración, Cómic y Creación Audiovisual
}

\title{
LA ADAPTACIÓN DE ÁLBUMES ILUSTRADOS INFANTILES AL MEDIO AUDIOVISUAL
}

\section{RESEARCH ON FILM ADAPTATION OF CHILDREN'S PICTURE BOOKS}

\author{
Autora: Sara Martínez Maiso \\ Tutora: $\mathrm{M}^{\mathrm{a}}$ Carmen Hidalgo Rodríguez \\ Ilustración infantil \\ Departamento de Dibujo
}

Febrero 2020 


\section{DECLARACIÓN DE AUTORÍA Y ORIGINALIDAD}

El plagio, entendido como la presentación de un trabajo u obra hecho por otra persona como propio o la copia de textos sin citar su procedencia y dándolos como de elaboración propia, conllevará automáticamente la calificación numérica de cero. Esta consecuencia debe entenderse sin perjuicio de las responsabilidades disciplinarias en las que pudieran incurrir los estudiantes que plagien.

El abajo firmante D./Dña. Sara Martínez Maiso con DNI 16640673N que presenta el Trabajo Fin de Máster con el título: "Adaptación de álbumes ilustrados infantiles al medio audiovisual", declara la autoría y asume la originalidad de este trabajo, donde se han utilizado distintas fuentes que han sido todas citadas debidamente en la memoria y dispone de la autorización y permisos pertinentes para la publicación de las imágenes y documentos.

Y para que así conste firmo el presente documento en Granada a 5 de Febrero de 2020

El autor:

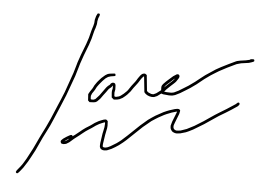




\section{ÍNDICE}

1. INTRODUCCIÓN 6

1.1. Justificación $\quad 7$

2. OBJETIVOS 8

3. METODOLOGÍA 9

4. ESTADO DE LA CUESTIÓN 11

4.1. El álbum y el libro ilustrado infantil en la actualidad 11

4.2. La adaptación audiovisual 12

4.3. Relación entre el original y la adaptación 15

5. ANÁLISIS DE LAS PUBLICACIONES INFANTILES 17 Y SUS ADAPTACIONES AUDIOVISUALES

5.1. Prospección 17

5.2. Ánalisis 19

5.2.1. Libro o álbum ilustrado 19

5.2.2. Adaptación audiovisual 20

5.3. Resultados 22

5.3.1. Libros y audiovisuales 22

5.3.2. Comparativa entre el original y la adaptación $\quad 58$

5.3.2.1. Tema y tono semejante 62

5.3.2.2. Tema y tono diferente 63

5.3.2.3. Tema semejante y tono diferente $\quad 64$

5.3.2.4. Tema diferente y tono semejante $\quad 65$

6. CONCLUSIONES 67

$\begin{array}{ll}\text { 7. BIBLIOGRAFÍA } & 69\end{array}$ 


\title{
Resumen:
}

La visualización de la misma historia en distintos medios es una experiencia a la que nuestra sociedad se encuentra acostumbrada, en especial si hablamos de la adaptación audiovisual de libros infantiles. Este trabajo se centra en los álbumes y libros ilustrados infantiles que han sido reversionados en el medio audiovisual, tratando las diferencias y similitudes entre ambos, estableciendo una clasificación según el tratamiento del tema y el tono del original en la película o cortometraje.

\begin{abstract}
:
Re-visualizing the same story through different media is an experience our society is used to, especially if we're referring to the cinematic adaptation of children's books. This research focuses on children's picture books that have been reversioned as audiovisuals, dealing with the differences and similarities between them and establishing a classification according to the treatment of the theme and the tone of the original work in the film or short film.
\end{abstract}

\section{Palabras Clave:}

Película, adaptación audiovisual, álbum ilustrado infantil, recreación cinematográfica

\section{Key Words:}

Film, shortfilm, film adaptation, children's picture book, picturebook 


\section{INTRODUCCIÓN}

La humanidad siempre ha contado historias, evolucionando de una tradición oral a una principalmente visual a lo largo de los siglos. Desde la creación de las tipologías móviles al final de la edad media, las historias escritas han logrado alcanzar a grandes audiencias a través del libro impreso. Más tarde, con el desarrollo en el siglo veinte de la litografía "offset", las nuevas técnicas gráficas y literarias permitieron a los autores poder contar sus historias a través de la interacción entre el texto y la imagen, dando lugar a lo que hoy llamamos ilustración. El desarrollo más reciente de esta tradición es el que engloba los medios audiovisuales, que abren las puertas a todo un nuevo mundo narrativo.

A pesar de que el concepto de adaptación audiovisual es siempre algo ambiguo, podemos definirlo como la transformación de una narrativa al menos en parte literaria a una completamente visual y auditiva. Si lo llevamos más lejos podemos decir que se trata de una práctica intelectual que reforma la estructura del texto para lograr hacerlo más adecuado para su supervivencia (Musfar, 2019).

Históricamente y hasta la fecha, la mayor parte de películas infantiles han sido adaptaciones de obras literarias, y a menudo han sido consideradas como copias con menos valor que original. Esta visión no tiene en cuenta la diferencia narrativa y estrategias estéticas que se deben tener en cuenta en el medio audiovisual en contra posición a las que se dan en la literatura. Afortunadamente, el aumento de estudios sobre la disciplina que estudia las relaciones mutuas entre diferentes medios y considera sus similitudes y diferencias ha provocado un cambio de actitud.

A día de hoy la mayor parte de las adaptaciones son interpretaciones de la historia original. No solo se limitan a imitar, pero las interrelaciones existentes entre el original y la adaptación ayudan a los niños a interpretarlos, ya que habiendo leído el libro o álbum pueden ver el audiovisual con un interés diferente. Esta es una de las razones por las que cuentan con gran aceptación social (Musfar, 2019).

La transformación de libros y álbumes ilustrados en películas presenta un reto para la educación mediática. Las historias ilustradas son formas de arte multimodal que familiarizan a los niños con la interconexión que existe entre texto e imagen, y por tanto pueden preparar el camino para que los niños entiendan películas que, verbal y visualmente, hacen referencia al medio de los libros ilustrados.

Pese a que las películas destinadas a preescolar a menudo son adaptaciones de historias de libros y álbumes ilustrados no hay demasiadas investigaciones respecto al proceso que ocurre al transformar dichos cuentos en audiovisuales. Basándonos en la literalidad visual y la audiovisual, cada medio exige de sus espectadores diferentes habilidades, aunque conocer el original siempre ayuda comprender el audiovisual de otra manera (Kümmerling-Meibauer, 2013). 


\subsection{Justificación}

El tema que aborda este trabajo es especialmente relevante debido a las escasas investigaciones y análisis elaborados al respecto.

El mercado del álbum ilustrado vive un momento de alza, cada vez más valorado a nivel cultural y, si hablamos en concreto de los libros dedicados a niños, podemos afirmar que el nivel de dedicación a este tipo de trabajos también vive un momento de gloria dentro de su propia historia.

De forma general, todos los productos destinados al público infantil son especialmente valorados en nuestra sociedad actual, creando su propio hueco en el mercado y en la cultura. Tanto es así, que las películas infantiles son una constante en la cartelera de los cines, disfrutadas tanto por niños como por adultos. $Y$ dentro de este género encontramos un gran nicho para las adaptaciones. No solo estamos hablando de obras originales puramente literarias, sino de álbumes y libros ilustrados para niños que se han reinterpretado para adaptarlos a la gran pantalla.

Este tipo de obras son interesantes por el proceso que deben de sufrir para su transformación a otro medio totalmente diferente como es el audiovisual, a menudo experimentando cambios en su trama, en el tono, en el estilo o en el tema, como parte de su adaptación a una franja de tiempo a menudo mucho más amplia y para la captación de otro tipo de interés que requieren los audiovisuales.

Estos cambios que experimenta la historia son los que trata este trabajo, teniendo en cuenta también el valor que este tipo de adaptaciones supone para la educación, ya que presenta al niño con un tipo de comunicador de historias diferente que le permite comparar su percepción original con la adquirida a través del audiovisual. El potencial didáctico que presentan las adaptaciones audiovisuales en conjunto con los libros originales es un recurso indiscutible para la enseñanza. 


\section{OBJETIVOS}

\section{Generales:}

- Conocer la situación del álbum y el libro ilustrado infantil en la actualidad.

- Trazar la historia de la adaptación audiovisual de cuentos infantiles.

- Entender la importancia de la adaptación cinematográfica y el público al que busca atraer.

- Plantear el interés didáctico que puede suponer la visualización de ambos medios.

- Presentar diferentes álbumes y libros que han sido adaptados en películas o cortometrajes.

\section{Específicos:}

- Realizar una prospección de libros infantiles que hayan sido adaptados a un audiovisual.

- Analizar las diferencias entre ambos medios, comparando la obra original y la adaptación audiovisual.

- Establecer unos rasgos comunes entre los tipos de adaptaciones. 


\section{METODOLOGÍA}

Para abordar este trabajo se ha estudiado en un primer paso la teoría ya existente y el estado de la cuestión en lo que respecta a los álbumes y libros ilustrados, las adaptaciones audiovisuales de los mismos y la relación que existe entre ambos. De este modo podemos conocer el contexto que rodea este tema, los estudios que puedan haberse realizado y la visión actual que la sociedad tiene al respecto.

En este caso no existe mucha teoría sobre la adaptación audiovisual de álbumes ilustrados, pero sí que la hay sobre la adaptación cinematográfica de forma más general y el papel que tiene en la sociedad. Múltiples trabajos tratan específicamente de algunas de las adaptaciones de las que se hablará más adelante, como "The lost thing" (Tan, 2000; Ruhemann, Tan, 2010) o "Where the wild things are" (Sendak, 1963; Jonze, 2009), al ser unas de las más conocidas y valoradas. También se ha escrito mucho sobre la fidelidad que las adaptaciones deben o no mantener, y el valor artístico que puedan tener al ser "derivados" del original, pero este es un tema que este trabajo no pretende abordar desde un punto de vista crítico, sino meramente objetivo.

Para comenzar a profundizar en el tema, se elaboró una lista de álbumes y libros ilustrados infantiles que de alguna manera hayan sido trasladados al medio audiovisual. De este modo se desarrolló una lista de más de 30 adaptaciones, incluyendo algunas series de televisión como "Clifford, The big red dog" (Norman Bridwell, 1963; John Over, 2000) o "The tale of Peter Rabbit" (Beatrix Potter, 1901; Jackson, 1992), clásicos literarios como "Alicia en el país de las maravillas" (Carrol, 1865) o "Pinocho" (Collodi, 1883), además de muchos audiovisuales que no suponían una gran diferencia del propio álbum al tratarse solo de pequeñas animaciones básicas con narración en off, como en el caso de "The very busy spider" (Eric Carle, 1984). También había muchas adaptaciones muy antiguas, de los orígenes de la animación (Weston Woods, etc.).

Así pues, la decisión fue limitar la lista a los ejemplos antiguos más interesantes, no contar con animaciones demasiado básicas y apartar los clásicos más reversionados. El resultado final es una selección de adaptaciones en su mayor parte elaboradas en las últimas décadas y que ejemplifican diferentes tipos de procesos adaptativos.

Para poder llevar a cabo el análisis de los álbumes y sus adaptaciones audiovisuales fue necesario la elaboración de un sistema de análisis que tuviera en cuenta, por un lado, las características propias de un libro impreso y, por otro lado, de un producto audiovisual. Con este fin se elaboraron unas fichas de análisis que recogen los detalles más importantes de los libros y los audiovisuales, desde el año de publicación hasta la técnica, estudiando los libros o álbumes por un lado y visionando por otro el largometraje o cortometraje adaptado.

Una vez elaborados estos breves estudios individuales es más fácil comparar y clasificar cada una de ellas dentro de un tipo de adaptación, a partir de lo cual se pueden desarrollar las conclusiones pertinentes. 
Los recursos metodológicos utilizados han sido básicamente dos: los recursos bibliográficos y los materiales de estudio, libros y audiovisuales.

A la hora de desarrollar la teoría se estudiaron diferentes trabajos académicos a cerca del tema en cuestón. Desde el reciente artículo de Musfar (2019) "Exploring Visual Perception and Children's Interpretation in Children Literature and its Adaptations" a los estudios de Unsworth (2013) "Re-configuring image-language relations and interpretive possibilities in picture books as animated movies: A site for developing multimodal literacy pedagogy" $y$ "Point of view in Picture books and animated movie adaptations". Aunque también han sido consultadas publicaciones más antiguas como "Children's Literature on Film: Through the Audiovisual Era to the Age of Telecommunications" (Schindel, 1981), para poder desarrollar la historia de las adaptaciones a lo largo de las décadas.

Libros como "Comparative Children's Literature" (O’Sullivan, 2005), o "Contemporary Children's Literature and Film: Engaging with Theory" (Mallan y Bradford, 2011), también han sido un gran soporte para la base teórica de este trabajo.

Así mismo, publicaciones como "Multiculturalismo y exclusión social en álbumes ilustrados: Método de análisis" (Hidalgo Rodríguez, 2015) o "Introduction: New Perspectives in Children's Film Studies" (Kümmerling-Meibauer, 2013), han sido un importante recurso a la hora de elaborar un método de análisis que aplicar a los libros y a los audiovisuales.

Los libros escogidos para ser analizados han sido: "El cazo de Lorenzo" (Carrier, 2010), "The lost thing" (Tan, 2000), Where the Wild Things Are (Sendak, 1963), "A day with Wilbur Robinson" (Joyce, 1990), "The Polar Express" (Van Allsburg, 1985), "Shrek!" (Steig, 1990), "The Gruffalo" (Donaldson, Scheffler, 1999), "Cloudy with a chance of meatballs" (Barret, 1978), "The Guardians of Childhood" (Joyce, 2010), "Horton hears a who" (Dr. Seuss, 1954), "The fantastic flying books of Mr Morris Lessmore" (Joyce, 2011), "Winnie the Pooh" (Milne, Shepard, 1926), "Rosie's walk" (Hutchins 1968), "The Ant Bully" (Nickle, 1999), "Lost and Found" (Jeffers, 2005), "Ferdinand" (Lawson, Leaf, 1936), "The boss baby" (Frazee, 2010) y "Les poings sur les îles" (Fontenaille, Lópiz, 2011).

La filmografía de este trabajo consiste en los cortometrajes y mediometrajes siguientes: "El cazo de Lorenzo" (Montchaud, 2014), "The lost thing" (Ruhemann \& Tan, 2010), "The Gruffalo" (Lang, Schuh, 2009), "The fantastic flying books of Mr Morris Lessmore" (Joyce, Oldenburg, 2011), "Rosie's walk" (Deitch, 1970), "Lost and Found" (Hunt, Lurie, Reutemann, 2008) y "Les poings sur les îles" (Lu Bing, 2013). Y los largometrajes: "Winnie the Pooh" (Lounsbery, Reitherman, 1977), "Where the Wild Things Are" (Jonze, 2009), "The Ant Bully" (Davis, 2006), "Cloudy with a chance of meatballs" (Miller, Lord 2009), "The boss baby" (McGrath, 2017), "The Polar Express" (Zemeckis, 2004), "Horton" (Hayward, Martino, 2008), "Ferdinand" (Saldanha, 2017), "Shrek" (Adamson, Jenson, 2001), "Meet the Robinsons" (Anderson, 2007) y "Rise of the Guardians" (Ramsey, 2012). 


\section{ESTADO DE LA CUESTIÓN}

\subsection{El álbum y el libro ilustrado infantil en la actualidad}

¿Qué implica el hablar de literatura infantil? En el pasado no existía una división entre literatura para niños y cualquier otro tipo, de hecho, no había ningún tipo de libros escritos para niños en particular. Más tarde los escritores reconocieron que las respuestas de los niños a la narración son diferentes a las de los adultos, por lo que se empezó a crear una literatura específicamente infantil. Este tipo de libros prestaba atención a las entusiastas mentes de los niños y se centraba en la fantasía, la historia, las aventuras y la vida cotidiana en el colegio o en casa. En el siglo XVIII la literatura infantil pudo transcender las fronteras lingüísticas y culturales cuando los primeros libros y revistas infantiles vieron la luz.

De acuerdo con Sullivan (2005) la literatura infantil es vista, desde un acercamiento basado en el sistema teórico, como un segmento específico y distintivo del sistema literario general que requiere una teoría propia. Tiene sus propios campos de actividad en marketing, editorial, librerías, enseñanza, crítica, etc., que la distingue de la literatura para adultos.

La importancia de ver las cosas desde el punto de vista del niño es esencial al escribir para ellos. Primeramente se utiliza lo que se percibe como el nivel de pensamiento del niño. Esta perspectiva ayuda a los jóvenes lectores a saber quién cuenta la historia y a quién. La mayor parte de los cuentos para niños narran la historia en tercera persona. La ficción para adultos utiliza distintos tipos de personajes para el papel de protagonistas, en la ficción infantil en cambio los niños son los principales protagonistas. De la misma forma los antagonistas acostumbran a ser adultos. La imaginación y la fantasía acostumbran a caracterizar la historia, que acaba con final feliz.

La literatura infantil se posiciona dentro de las influencias en comportamiento y formación de la moralidad de los niños. En la mayor parte de los cuentos encontramos un mensaje moralista, un método didáctico que trata de enseñar a distinguir el bien y el mal. Como destacaba Piaget, para los niños hasta ciertas edades la idea de casualidad y coincidencia tiene muy poca importancia, por lo que si el "malo" de la historia acaba perdiendo será precisamente por ser "malo".

A día de hoy los adultos deciden lo que los niños deben consumir, en la mayor parte de los casos hablan por ellos en lugar de dejar que expresen sus deseos. Algunos críticos se refieren a esto como la "colonización" adulta de los niños. Los profesores, bibliotecarios y otros educadores seleccionan libros para los más pequeños sin prestar atención a sus preferencias. Por eso muchas veces las expectativas de los niños difieren y pueden quedar insatisfechos. (Musfar, 2019, p. 23-42).

Cuando hablamos de álbum ilustrado estamos tratando un tipo muy específico de literatura infantil. Como dice Orozco (2009):

"El mundo de los libros para niños acoge una nueva propuesta de lectura como resultado de la convivencia entre diversos lenguajes: el libro 
álbum, un texto en donde existe una relación interdependiente entre texto e imagen. No se puede entender uno sin considerar al otro." (p.2)

Autores como Senís (2004, p.116) u Ospina (2010, p.59-61) defienden la importancia del álbum ilustrado en los niños pequeños para ayudar a fomentar la lectura, propiciando el desarrollo de personas críticas y competentes, con hábito lector. Es por esto por lo que se habla de tratar el álbum o bien como proyecto o como recurso educativo.

Cada vez se valora más la función educativa de la ilustración, a la par que crece su relevancia dentro de la creación editorial infantil, pasando de ser un elemento de apoyo para el texto a asentarse como parte integrante de la propia narración. Esta evolución se relaciona con los cambios culturales y con el desarrollo de nuevas formas de lectura.

Con la aparición de los medios audiovisuales surge la necesidad de construir un nuevo lenguaje de códigos gráficos. Es este interés formativo lo que impulsa tanto a ilustradores como a editores a experimentar con el potencial expresivo de técnicas diferentes, no solo en la página en sí, sino en el propio diseño del objeto-libro.

La era digital ha traído consigo nuevas maneras en las que nos relacionamos con los textos y estos se relacionan entre sí. Así es como la lectura secuencial está abriendo paso a la navegación hipertextual, mediante la cual saltamos de una idea a otra a través de enlaces al leer en nuestros ordenadores o móviles, combinando imágenes y palabras, percepciones visuales e incluso sonidos. Esta forma de lectura influye en la concepción actual del libro infantil, que se está desarrollando con un creciente despliegue de recursos que integran lo gráfico y lo verbal.

\subsection{La adaptación audiovisual}

La visualización de la misma historia en papel y en medios digitales se ha convertido en una experiencia casi rutinaria en la cultura literaria actual para un cierto rango de edad y del espectro social que no hace sino expandirse. En la actualidad algunas historias se componen para el formato digital de la imagen en movimiento, como es el caso de "The fantastic flying books of $\mathrm{Mr}$ Morris Lessmore" (Joyce, 2011). Un creciente número de autores de álbumes ilustrados están produciendo de forma simultanea el formato a papel y digital de sus historias, como "The heart and the bottle" y su correspondiente aplicación para el iPad (Jeffers, 2009), y como recreaciones multimedia de trabajos literarios ya establecidos que ayudan a acercarlos a la cultura popular.

La adaptación de cuentos infantiles a la pantalla la lideró en gran parte Disney en la década de 1950 en Estados Unidos, adaptando a pequeños cortos como "Little House" de Virginia Lee Burton, el cuento de Hardie Gramatky "Little Toot", y "Ferdinand the Bull" de Robert Lawson, aunque ya anteriormente había visto la luz "Blancanieves" (1937). Estaban dirigidas tanto a adultos como a niños y destinadas a proyectarse en el cine, alterando consistentemente la 
historia y el centro de antención de la obra original, lo que acabaría convirtiéndose en el sello de identidad de todas las adaptaciones de Disney: un cambio en el tono y el tema del material que llevan a la gran pantalla.

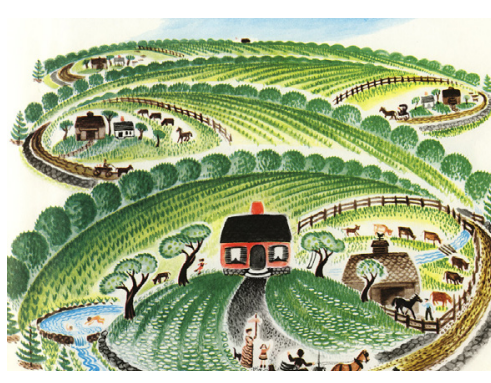

"Little House" Lee Burton, 1942

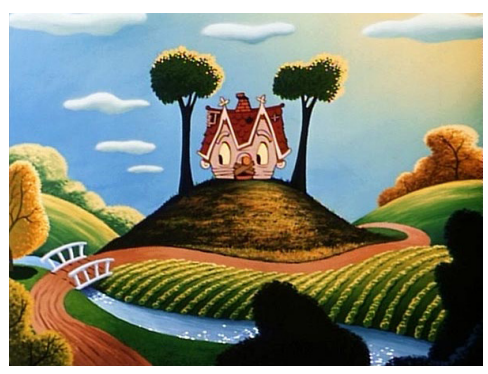

“The Little House” Disney, 1952

El primer intento de traducir fielmente tanto el texto como las ilustraciones al medio audiovisual fue en 1952, de la mano de "United Productions of America" y Ludwig Bemelman, con el metraje "Madeline". Pero pese a ser un éxito artístico no triunfó comercialmente, por lo que se quedó en un esfuerzo aislado (Schindel, M., 1981).

A lo largo de muchas décadas, numerosos cuentos ilustrados infantiles ingleses han sido reproducidos como películas animadas. Una de las compañías más conocidas por estas adaptaciones es Weston Woods, en Estados Unidos. Álbumes como "Rosie's walk" (Hutchins, 1968) pronto aparecieron como cortos animados (Deitch, 1970) al igual que el clásico de Maurice Sendak (1962) "Where the wild things are" (Deitch, 1973).

Otros clásicos como el conocido "The tale of Peter Rabbit" de Beatrix Potter se han convertido en series animadas de la televisión (Jackson, 1992).

Un gran número de conocidos cuentos ilustrados se han producido como versiones animadas en formato CD-ROM. Por ejemplo "George shrinks" (Joyce 1985 \& c1994), "Stellaluna" (Cannon, 1993; Random House/Broderbund, 1996) y "The polar express" (Van Allsburg, 1985 \& 1997).

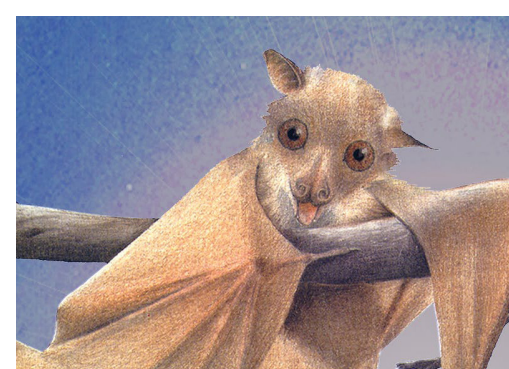

“Stellaluna” Janell Cannon, 1993

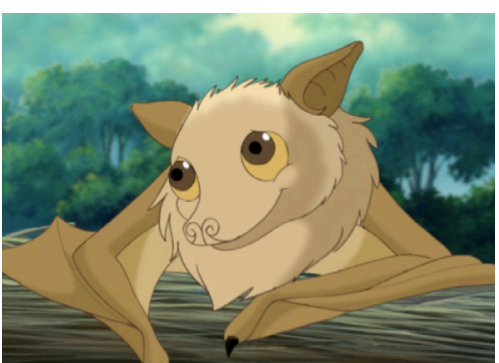

"Stellaluna” Kowalchuk, 2003 
En los últimos años hemos vivido el frecuente éxito en taquilla de adaptaciones en película de cuentos infantiles ilustrados. Este es el caso de "Where the wild things are" (Jonze, 2009), "Fantastic Mr Fox" (Anderson, 2009) adaptación del libro ilustrado de Roald Dahl (1974), "The polar express" (Zemeckis, 2004) del conocido libro ilustrado de Chris Van Allsburg (1985) y "Hugo" (Scorsese, 2011) de la historia ilustrada "The invention of Hugo Cabret" de Brian Selznick (2007), ganadora de una medalla Caldecott. (Unsworth, 2013, p.29)

Numerosos estudios demuestran que la reconsumición de historias en lo que respecta a libros y películas es algo que los espectadores buscan y que agrada al público. Se trata de un proceso dinámico que puede experimentarse como una nueva experiencia.

De acuerdo con un artículo de Russell and Levy (2012) hay tres tipos de productos hedonistas, libros, películas y lugares, en el que la reconsumición se definen como "experiencias de consumo que se busca activamente experimentar de nuevo" (p.341).

Esto se relaciona con la riqueza de significado, profundidad y capacidad de emocionar de estos productos. En el caso de la visualización de una película se experimentan gran variedad de emociones tanto positivas como negativas que conjugan la evaluación de la misma. Estas experiencias de repetición están enlazadas emocionalmente, aportando una forma de resonancia afectiva que se cataliza en la re consumición (Russell and Levy, 2012). Los lectores y espectadores son más emocionalmente eficientes cuando anticipan y buscan los puntos álgidos de la obra, sabiendo que el clímax es fácil de conseguir. Además, pueden estar buscando refinar la experiencia mediante la repetición (Collins, Hand y Linnell, 2008).

En el caso específico de las adaptaciones audiovisuales, la re-consumición presenta ciertas particularidades. Cuando los espectadores ven una película tras haber leído el libro, están volviendo a experimentar la misma historia a través de un medio completamente distinto con diferencias técnicas muy específicas (Aurier y Guintcheva, 2014).

Los audiovisuales dirigidos a niños deben tener en cuenta el estado en el desarrollo cognitivo, emocional y lingüístico en el que se encuentra el público objetivo.

La industria de las películas infantiles no hace sino expandirse, incluido el mercado de productos de merchandising. Debemos tener en cuenta que a menudo las adaptaciones audiovisuales buscan apelar a un receptor, no solo se busca entretener a los niños sino también a los adultos. En la construcción fílmica se entrecruzan elementos principalmente dirigidos a los niños, como por ejemplo humor escatológico o de parodia épica (Díaz Armas, 2005), con elementos que apelan claramente a un público adulto, a menudo jugando con la intertextualidad.

Frecuentemente puede parecer que las películas infantiles muestran una cierta preferencia por géneros específicos, en torno a los cuentos de hadas, animales o aventuras, y frecuentemente usando animación. Un género que 
aparece con frecuencia es el del viaje o la misión emprendida por una persona mayor y un niño (Kümmerling-Meibauer, 2013).

\subsection{Relación entre el original y la adaptación}

La traslación de cuentos ilustrados a películas es una tradición que lleva manteniéndose décadas y continua como una parte significativa de la cultura popular. La experiencia de lo que puede ser la misma historia tanto en papel como en medio digital se ha convertido en un aspecto sustancial y casi rutinario en la cultura literaria para un creciente número de personas. Las generaciones mayores aun cuentan con una perspectiva cronológica en la producción del libro, la película, el vídeo juego... pero las generaciones más jóvenes han crecido para encontrarse con estas historias accesibles de manera simultanea en varios formatos.

Tradicionalmente, este campo de la investigación se centra en el debate en torno a la fidelidad de la adaptación al material original contra una interpretación más creativa donde el énfasis no se pone en la fuente sino en la forma en la que su espíritu, atmósfera y alma son reconstruidos en el proceso de la recepción (Welsh y Lev, 2007).

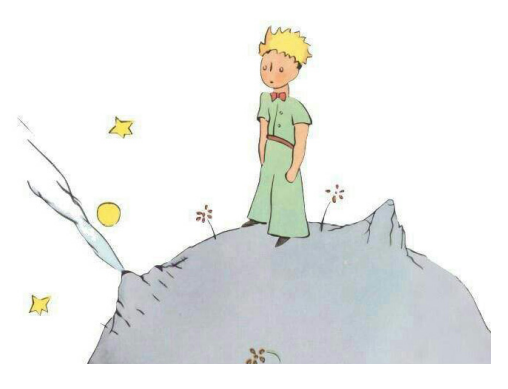

“Le Petit Prince” Saint-Exupéry, 1943

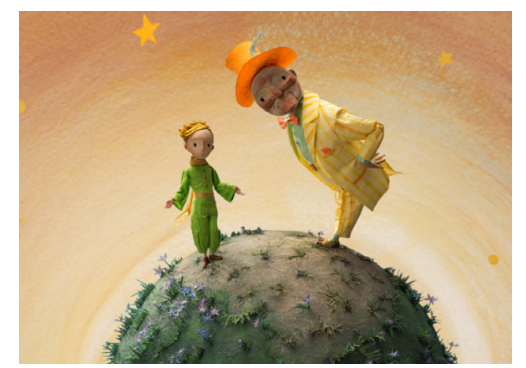

"Le Petit Prince" Osborne, 2015

En ocasiones los adultos perciben que la apariencia de ciertos personajes en las películas no es como la habían imaginado al leer el libro, o que la película omite algunos aspectos de la narración del libro. Pero en los niños parece haber una tendencia a eludir cualquier diferencia entre las versiones de la historia, especialmente en lo que respecta a las versiones animadas de cuentos ilustrados. Esto puede deberse en parte a que la animación se mantiene fiel a las ilustraciones originales en la apariencia de los personajes y como normalmente los álbumes ilustrados son muy cortos la omisión de detalles de la historia no es un problema en estas adaptaciones. Además, si bien en algunas historias como "Stellaluna" (Cannon, 1993) las diferencias entre el libro y la versión animada son patentes, en otras historias como "George Shrinks" (Joyce, 1985) y "The Little Prince" (Saint-Exupéry, 1943) son más sutiles, pero igualmente significativas en términos de su influencia en la variación de las posibilidades interpretativas de las dos versiones. Estos matices pueden no ser percibidos por el lector o espectador menos experimentado. También 
puede ser que la forma en la que se lidia con las múltiples versiones de una historia en la escuela no hace alusión a la construcción de la misma a través de decisiones sobre los recursos y significación del lenguaje y la imagen (Unsworth, 2013).

En el proyecto de investigación de Macken-Horarik, Unsworth, y Love, (20112013) se entrevistó a una niña de cuarto año de colegio que había trabajado en clase tanto el libro como la película de "The Lost Thing" (Tan, 2000; Ruthemann y Tan, 2010):

Daki: ... And I think he actually found the lost thing so that he could open up and actually not be lost himself.....that's why... that's the purpose of the lost thing in him... I think.

Researcher A: And was that in the book or the movie that you are talking about? Or did you look at both?

Daki: Well we had the book, but we watched the movie as well.

Researcher B: Yes, so maybe that's the movie because I don't remember the ending of the book being like that. That's interesting. So you've done the book and the movie.

Daki: Well we had a look at the book. Yeah, but mostly the movie. ${ }^{1}$

La estudiante hacía una interpretación muy plausible sobre lo que la película muestra de la historia, pero, aunque esa interpretación es posible leyendo el álbum, sustraer semejante conclusión sería todo un reto. Es por esto que el hecho de que la estudiante evada las diferencias entre ambas versiones de la historia no haga sino remarcar la necesidad de trabajar la literatura en las aulas, incorporando la enseñanza de recursos visuales y lingüísticos que construyen y cambian el significado de la historia. Otro recurso didáctico muy efectivo y disfrutable es la comparativa entre ambos medios. Las películas muestran una tendencia a ser más evidentes, incluso explícitas, mientras que los álbumes suelen ser más ambiguos. Estos últimos pueden están pensados para ser interpretables, para que el lector sea activo y complete o interprete de alguna manera la información.

1 Daki: ... Y creo que encontró a la cosa perdida para poder abrirse y no estar perdido él mismo... por eso... ese era el propósito de la cosa perdida en él... creo. Invnestigador A: ¿Esto es en el libro o en la película? ¿O estás hablando de ambos? Daki: Bueno, teníamos el libro, pero también vimos la peli.

Investigador B: Claro, así que eso a lo mejor está en la película, porque no recuerdo que el libro termine así. Es interesante. Así que has estado con el libro y la peli.

Daki: Bueno, echamos un vistazo al libro, sí, pero sobre todo la peli. 


\section{ANÁLISIS DE LAS PUBLICACIONES INFANTILES Y SUS ADAPTACIO- NES AUDIOVISUALES}

\subsection{Prospección}

Al hablar de adaptaciones en la actualidad lo primero que debemos hacer es limitar la búsqueda. En este caso no tratamos las novelas y clásicos literarios que han sido llevados al cine, ni tampoco las novelas gráficas y cómics, un género tan en alza en los últimos tiempos, donde no podemos pasar ni un mes sin oír hablar de la nueva adaptación de cómic de superhéroes. En este caso nos centramos en la literatura infantil, concretamente la ligada a la ilustración.

En un inicio la lista de álbumes y libros ilustrados infantiles incluía algunas novelas con dibujos como la saga "How to train your dragon" (Cowell, 2003) y clásicos literarios infantiles que se han ilustrado en algún momento como puede ser "Blancanieves" (Grimm, 1812).

La lista de audiovisuales también incluía series de televisión como "Clifford, The big red dog" (Norman Bridwell, 1963; John Over, 2000) o "The tale of Peter Rabbit” (Beatrix Potter, 1901; Jackson, 1992) y clásicos adaptados múltiples veces como "Alicia en el país de las maravillas" (Carrol, 1865) o "Pinocho" (Collodi, 1883). Además, es fácil encontrar audiovisuales que no suponen una gran diferencia con el propio álbum al tratarse de pequeñas animaciones básicas con narración con voz en off y melodías sencillas, como en el caso de "The very busy spider" (Eric Carle, 1984) cuya versión animada podemos encontrar en fácilmente en YouTube, y versiones aun más sencillas en las que nada es animado pero la cámara se mueve sobre las ilustraciones del álbum y se narra el texto.

El primer paso es reducir la lista a una selección que solo incluyera historias infantiles en las que las ilustraciones fueran parte transcendente de la obra; es decir: libros ilustrados, en los que el texto se acompaña de ilustraciones que reflejan imágenes de la historia que se está narrando, y sobre todo álbumes ilustrados, en los que se integran texto e ilustración, con una preponderancia de la parte gráfica. Además, se quedan fuera los libros que son reversiones y casi todos los más antiguos. Los audiovisuales no incluyen series de televisión ni animaciones básicas, además casi todos son obras de las últimas décadas, con solo algún ejemplo de épocas anteriores por ser especialmente relevantes o significativos, añadiendo variedad a la selección.

Algunos autores cuentan con varias obras llevadas a la pantalla como por ejemplo Dr. Seuss ("The Grinch", "Horton hears a who", "Lorax", "Cat in the Hat", (1904-1991); Ron Howard, 2000; Jimmy Hayward, Steve Martino, 2008; Chris Renaud, 2012; Bo Welch, 2003), Steig (“Shrek!", 1990; Adamson y Jenson, 2001. "George shrinks", 1993; serie de Jade Animation, Nelvana, 2000), Chris van Allsburg ("Jumanji”, 1981; Johnston, 1995. "Zathura", 2002; 2005. "The Polar Express", 1985; Zemeckis, 2004) o Joyce ("A day with Wilbur Robinson", 1990; Stephen J. Anderson, 2007. "The Guardians of Childhood", 2010; Peter Ramsey, 2012. "The fantastic flying books of Mr Morris Lessmore”, 2011; Joyce, Oldenburg, 2011). 
Pero en lo que respecta a este trabajo, solo es Joyce el que aparece con varias obras, ya que sus adaptaciones han sido muy diferentes, elaboradas por productoras y directores completamente distintos, dando lugar a resultados con características individuales propias. Otras obras, como en el caso de "Winnie the Pooh" (A. A. Milne, E. H. Shepard, 1926; John Lounsbery, Wolfgang Reitherman, 1977), han sido versionadas múltiples veces, pero en este caso solo se ha habla de uno de los audiovisuales que ha inspirado por ser el más representativo.

Nos encontramos pues con 18 originales y sus adaptaciones audiovisuales, la mayoría re-versionadas en las últimas décadas como cortometrajes, mediometrajes o largometrajes. A partir de aquí nos enfocamos en el registro y análisis de cada una de ellas, estableciendo una serie de datos para comparativa entre ellas.

Esto nos permite establecer una clasificación en la que distribuir los tipos de adaptaciones, que podemos deducir a partir de las fichas realizadas sobre cada una de ellas. De esta manera podemos ver diferentes tendencias dentro de este género y las interrelaciones que presentan la obra original y el producto audiovisual. 


\subsection{Análisis}

Para comenzar a analizar los álbumes o libros ilustrados, las adaptaciones audiovisuales y la relación entre ambos, hemos de marcar unas pautas a seguir con respecto a los aspectos a destacar y analizar en cada uno de ellos.

Son muchos los enfoques que podemos aplicar al tratar con las adaptaciones, por ejemplo, sinos fijamos en la obra de Shaun Tan: "The lost thing" (Tan, 2010; Ruhemann, Tan, 2010) observamos como ambas versiones son la misma historia, siendo casi idéntico el contenido, con solo cambios mínimos en la narración verbal. Tanto el álbum como el cortometraje utilizan esencialmente el mismo estilo en el diseño de personajes, sin ser realista ni naturalista, adentrándose en la caricatura, por lo que parecen prácticamente iguales en ambos medios. Lo que sí es diferente es la utilización de los aspectos interpersonales de las imágenes que construyen la relación interactiva entre los participantes representados y el espectador. Esto sucede gracias a la distancia social y la naturaleza del contacto adquirido por la manera de mirar de los personajes directamente al espectador (Kress \& van Leeuwen, 2006), así como la diferencia en el punto de vista. (Unsworth, 2013, p.30). Esto, combinado con la predominancia de ilustraciones que sitúan al lector como espectador a larga distancia en el álbum comparadas con los planos cortos e imágenes de contacto del cortometraje, contribuyen al compromiso del lector con la historia a papel como un observador apreciativo, pero de alguna manera distanciado. Sin embargo, en el audiovisual el espectador se ve a sí mismo en los zapatos del personaje, empatizando más.

Pero este enfoque se centra demasiado en el tipo de conexión del espectador con la obra y exige un análisis mucho más profundo y detallado sobre el trabajo de cámara, los planos y la posición del lector respecto a la obra a papel.

Este trabajo pretende analizar el original y el audiovisual de forma más general, estableciendo el registro de ambos, el formato, la técnica utilizada, el contenido, el protagonista, etc. Además, se fija en el tratamiento del tono y el tema en la adaptación con respecto al libro o álbum original.

\subsubsection{Libro o álbum ilustrado}

Así pues, al hablar del libro o álbum ilustrado elaboraremos un REGISTRO con el Título, el Autor, el Año de publicación, la Editorial y el Público objetivo. Estableceremos el género a partir de los temas que se establecen en "Multiculturalismo y exclusión social en álbumes ilustrados: Método de análisis" (Hidalgo Rodríguez, 2015):

- Realista: Encuadramos aquí los cuentos que son creíbles en el mundo real.

- Fantástico: Relatos que no son posibles en el mundo real.

- Clásico: Adaptaciones de las obras clásicas de la literatura infantil y juvenil.

- Cotidianeidad: Implica realismo pero además una historia que gira en torno a la vida diaria del niño/a protagonista. 
- Realidad mágica: Cuentan una historia real pero de forma maravillosa. En algún momento la historia se vuelve mágica y luego aterriza de nuevo en el mundo real.

- Poético: No existe una historia narrativa clásica (con introducción, nudo y desenlace), no sucede nada concreto. Se juega con alguna idea con el objeto de deleitar con el texto y la imagen. El texto suele estar escrito a modo de poesía.

- Abstracto: A diferencia del anterior sí existe una historia concreta, pero maneja conceptos abstractos reflejados en los personajes o en sus acciones. (p. 592-593)

Hablaremos además de la ILUSTRACIÓN, centrándonos en la Técnica, la Iconicidad y lo que el dibujo Transmite.

En cuanto al FORMATO distinguiremos entre Álbum ilustrado o de Libro ilustrado.

Anotaremos también datos sobre el ejemplar original, el TAMAÑO DEL LI$\mathrm{BRO}$, el tipo de Encuadernación y el Número de páginas.

La RELACIÓN IMAGEN/TEXTO, que puede ser de Complemento, es decir, que el texto y la imagen cuentan la misma historia complementándose de manera que la ilustración no tiene porqué relatar todo lo que dice el texto y puede incluso aportar más información; o de Contrapunto, donde el texto y la imagen cuentan historias diferentes que pueden incluso contradecirse (Nikolajeva y Scott, 2001).

Es importante hablar del PROTAGONISTA de la historia porque en ocasiones es diferente en la adaptación. Otro punto a registrar es si se trata del narrador.

En cuanto al CONTENIDO haremos una breve Sinopsis del libro o álbum y hablaremos del Mensaje que busca transmitir si es que hay alguno.

\subsubsection{Adaptación audiovisual}

En cuanto al análisis de la adaptación audiovisual, estableceremos también un REGISTRO con el Título, el Director, la persona o personas responsables del Guion, la Productora, que en ocasiones será una gran compañía como Dreamworks o Disney y otras veces un estudio pequeño independiente; el Año de estreno del audiovisual, el País en el que fue producido, el Público objetivo al que se dirige y la Duración. En ocasiones también hablaremos de si existe o no narración y voz en off o algún tipo de efecto especialmente notable.

Indicaremos el GÉNERO del cortometraje o película según lo establecido por la propia compañía, pudiendo ser ciencia ficción, aventuras, humor, drama, etc.

Señalaremos la TÉCNICA, ya sea personas reales, stop motion, animación 3D o animación 2D. en algunos casos se podrá desarrollar más la técnica que 
en otros, tales como los generados por ordenador sobre los que no se puede elaborar mucho.

EI FORMATO puede ser largometraje, cortometraje o mediometraje.

EI PROTAGONISTA es importante debido a los cambios que puede sufrir, como hemos indicado anteriormente, si se mantiene igual no se mencionará.

EI CONTENIDO, con la Sinopsis y el Mensaje solo se especificarán en caso de diferir del original.

Otro punto a tener en cuenta será la ADAPTACIÓN, en el que se desarrollará las similitudes y diferencias con el original y la forma en la que se ha tratado el tema y el tono.

El tema es el asunto o la materia que trata la historia, por lo que va ligado al argumento y la trama. Se refiere al contenido y es independiente del género, tratándose de la idea global que sustenta el planteamiento y las acciones. En una misma historia pueden existir varios temas, pero acostumbra a haber uno principal.

El tono se refiere al modo específico en el que se está expresando la historia, la actitud que el autor toma en cuanto al tema, personajes o eventos, e incluso la propia audiencia. El tono puede ser formal, informal, poético, solemne, sombrío, activo, misterioso, serio, irónico, condescendiente, tierno, humorístico y todo aquello que tiene que ver con la actitud de la voz del narrador en el álbum o libro, y en el caso del audiovisual del guión. Podemos decir entonces que el tono refleja el estado de ánimo de la historia que percibe el espectador o lector, por lo que se utiliza para transmitir emoción.

En el caso de las adaptaciones estableceremos si se han mantenido el tema y el tono o han sufrido cambios al pasar al audiovisual.

Así pues, en el siguiente apartado, cuando hablemos de los resultados de este análisis, podremos observar a un lado el libro o álbum ilustrado infantil y al otro la adaptación audiovisual, para poder comprender ambos en un mismo golpe de vista. 


\subsection{Resultados}

\subsubsection{Libros y audiovisuales}

1a. Libro: La petite casserole d'Anatole. Isabelle Carrier, 2010

\section{REGISTRO}

Título: El cazo de Lorenzo

Autora: Isabelle Carrier

Año de publicación: 2010

Editorial: Juventud

Público objetivo: niños a partir de 5-6 años

\section{GÉNERO}

Cotidianeidad

\section{ILUSTRACIÓN}

Técnica: línea con lápices de color y grafito

Iconicidad: caricatura

Transmite: ternura, sencillez

FORMATO
Álbum ilustrado

TAMAÑO DEL LIBRO

$25,5 \times 19 \mathrm{~cm}$. Horizontal

Encuadernación: tapa dura. Cartoné $\mathrm{N}^{\circ}$ de páginas: 40

\section{RELACIÓN IMAGEN/TEXTO Complemento}

\section{PROTAGONISTA}

Lorenzo, un niño con diversidad funcional

\section{CONTENIDO}

Sinopsis: el día a día de un niño con discapacidad intelectual, sus dificultades, sus cualidades, los obstáculos que tiene que afrontar. Gracias a la ayuda de personas que saben lo que es lidiar con esas dificultades consigue convertirlas en un recurso y centrarse en lo positivo sin dejar de ser él mismo.

"Lorenzo siempre arrastra un cazo detrás de él. El cazo se le cayó un día encima... No se sabe muy bien por qué. A causa de este cazo, Lorenzo ya no es del todo como los demás. Necesita mucho cariño. A veces es casi molesto. Es muy sensible y tiene un gran sentido artístico. Le encanta escuchar música. Tiene un montón de cualidades. Pero a menudo las personas solo ven ese cazo que arrastra por todas partes."

Mensaje: hablar de las diferencias a los niños mediante un cuento metafórico sobre toleracia y superación. (Diversidad funcional)

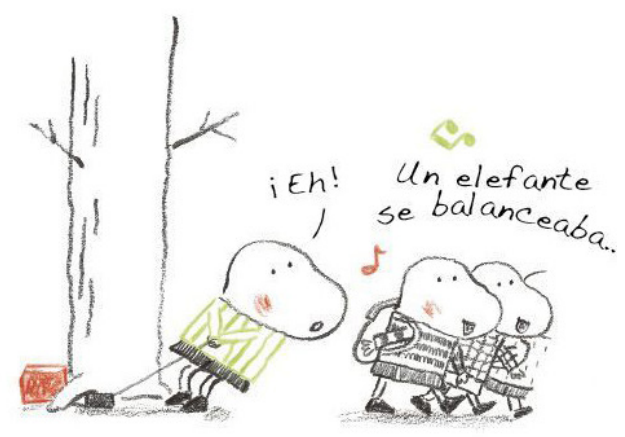

... y le impide avanzar. 
1b. Audiovisual: La petite casserole d'Anatole. Éric Montchaud, 2014

\section{REGISTRO}

Título: El cazo de Lorenzo

Director: Éric Montchaud

Guion: Eric Montchaud

Productora: JPL FILMS

Año de estreno: 2014

País: Francia

Público objetivo: niños de 5 a 10 años

Duración: 6 minutos

Audio: Música y narración con voz en off.

Efectos especiales: Onomatopeyas y diálogo aparecen escritos como en el álbum

\section{GÉNERO}

Cotidianeidad

\section{TÉCNICA}

Animación mediante "stop motion" con marionetas de madera pintada y tela, con fondos sencillos también con volumen con colores predominantemente azulados

\section{FORMATO}

Cortometraje animado.

\section{ADAPTACIÓN}

Se mantiene fiel al original, conservando el estilo de las ilustraciones aunque cambie la técnica, traduciendo los dibujos al 3D del stop motion mediante marionetas. Respeta el mensaje original y la historia casi paso a paso, añadiendo solo algunas acciones y alargando otras. La narración es muy similar a la del libro y no hay diálogos.

Así pues podemos decir que el tema y el tono son idénticos.

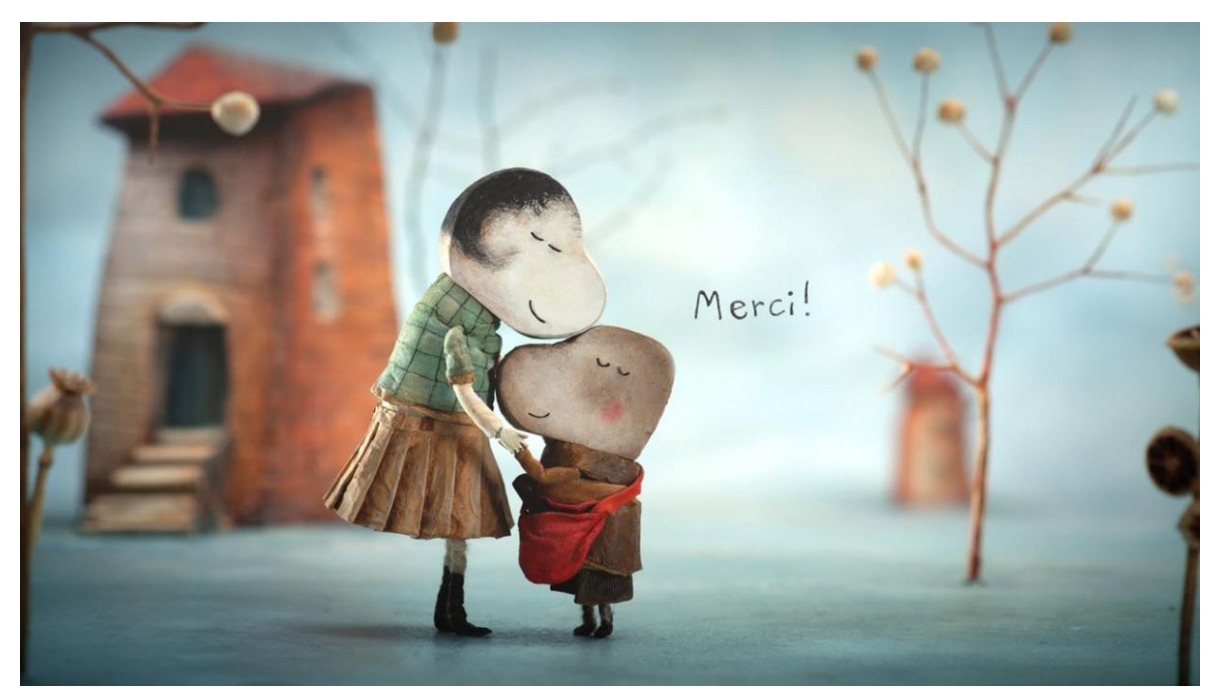


2a. Libro: The lost thing. Shaun Tan, 2000

\author{
REGISTRO \\ Título: La cosa perdida \\ Autor: Shaun Tan \\ Año de publicación: 2000 \\ Editorial: Lothian Books \\ Público objetivo: niños a partir de 9 \\ años
}

\section{GÉNERO \\ Fantástico}

\section{ILUSTRACIÓN}

Técnica:Capas finas de acrílico de base y acabado en óleo, collage

Iconicidad: caricatura

Transmite: visualmente muy rico y denso con dibujos muy elaborados. Fondos de la ciudad fríos e industriales, matemáticos

\section{FORMATO \\ Álbum ilustrado}

\section{TAMAÑO DEL LIBRO \\ $21 \times 30 \mathrm{~cm}$}

Encuadernación: tapa dura

$\mathrm{N}^{\circ}$ de páginas: 32

\section{RELACIÓN IMAGEN/TEXTO \\ Complemento}

\section{PROTAGONISTA}

El narrador, un chico que encuentra la cosa perdida

\section{CONTENIDO}

Sinopsis: un chico descubre una criatura de aspecto extraño, mientras recoge tapones de botellas en la playa. Le parece que la cosa está perdida e intenta descubrir a quién pertenece y decide buscarle un lugar en el mundo en el que pueda encajar. Sin embargo, a su alrededor, nadie se muestra dispuesto a ayudar. Extraños, amigos, familiares... cada uno a su manera rehúsa prestar atención a esa interrupción inesperada de su rutina. Lo que quizá nadie ha pensado es que la extraña criatura solo está perdida en la medida en que nadie repara en ella.

Mensaje: fomentar la curiosidad, fábula sobre todo tipo de preocupaciones sociales. El ser diferente, la soledad, la amistad, hacerse mayor

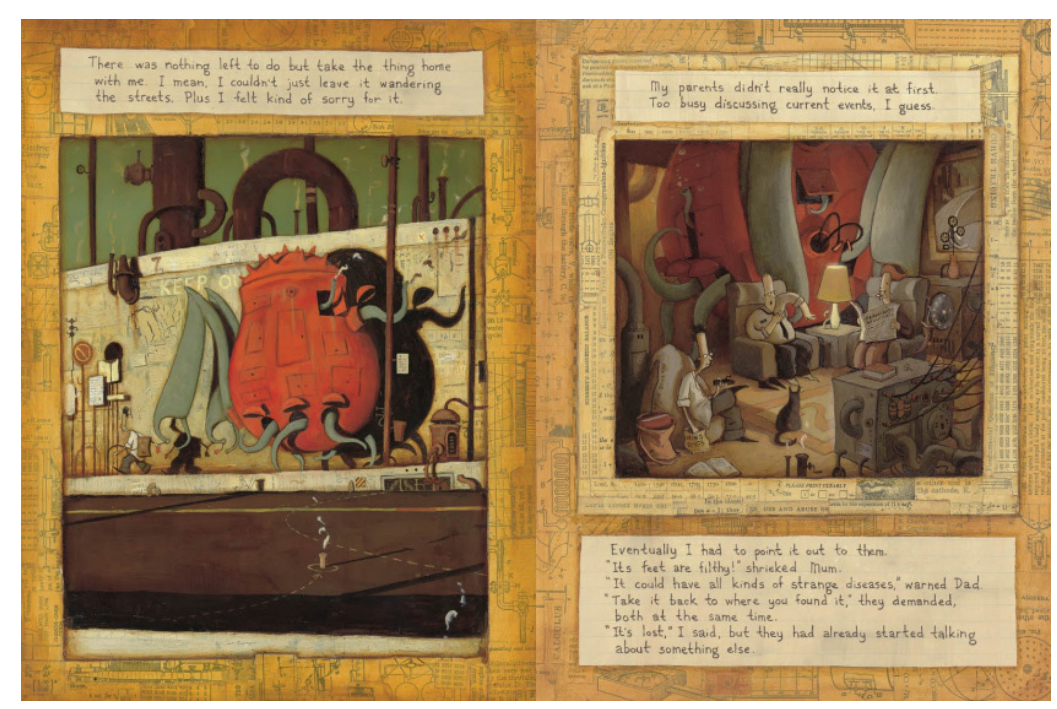


2b. Audiovisual: The lost thing.

Andrew Ruhemann \& Shaun Tan, 2010

\author{
REGISTRO \\ Título: La cosa perdida \\ Director: Andrew Ruhemann, Shaun \\ Tan \\ Guion: Shaun Tan \\ Productora: Coproducción Austra- \\ lia-Reino Unido; Passion Pictures \\ Año de estreno: 2010 \\ País: Australia \\ Público objetivo: a partir de 9 años \\ Duración: 15 minutos \\ Audio: Música y narración con voz \\ en off

\section{GÉNERO \\ Ficción} \\ TÉCNICA \\ Animación 3D, CGI \\ FORMATO \\ Cortometraje animado
}

\section{ADAPTACIÓN}

Mantiene el estilo del álbum ilustrado a través de la animación generada por ordenador, pero introduciendo también la misma técnica de collage en ciertas partes. La narración responde a la del libro, siendo el narrador el protagonista.

Algunas secuencias no tienen narración, sino que se muestra a través de acciones con más detalle que en álbum. En ocasiones se posiciona al espectador como uno de los personajes para provocar empatía, a diferencia de en el libro donde todo se observa como un escenario.

El tema y el tono son similares.

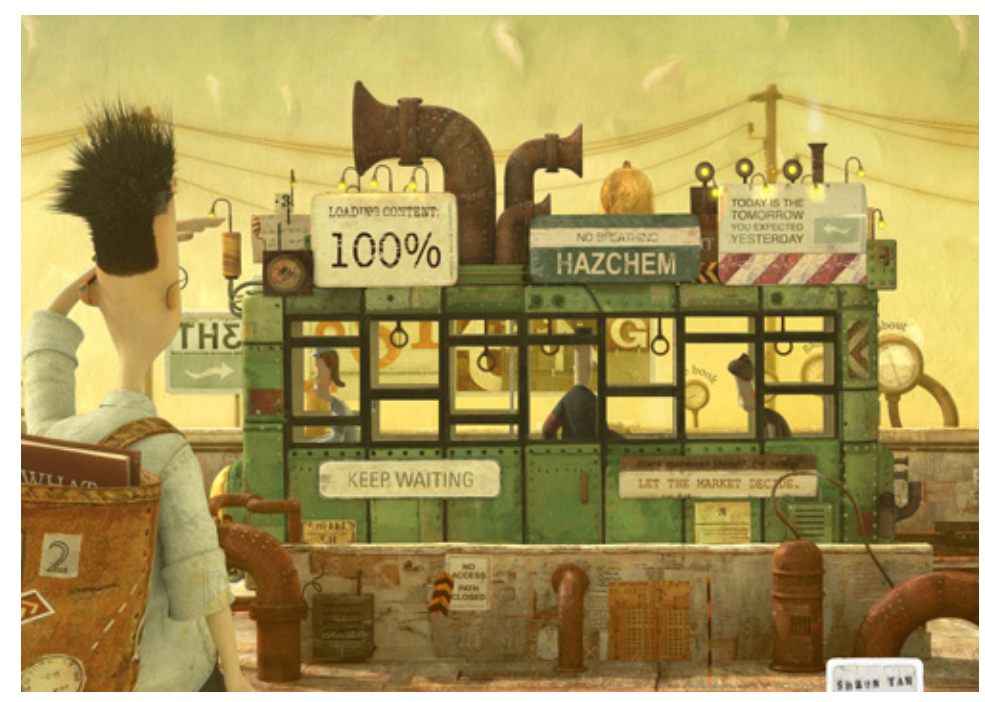


3a. Libro: Where the Wild Things

Are. Maurice Sendak, 1963

\author{
REGISTRO \\ Título: Donde viven los monstruos \\ Autor: Maurice Sendak \\ Año de publicación: 1963 \\ Editorial: Harper \& Row \\ Público objetivo: niños a partir de 3 \\ años

\section{GÉNERO} \\ Fantástico, realismo mágico
ILUSTRACIÓN
Técnica: Dibujo muy texturado a tinta y bolígrafo, coloreado
Iconicidad: caricatura realista
Transmite: el poder de la imagina- ción de un niño

\section{FORMATO \\ Álbum ilustrado}

\section{TAMAÑO DEL LIBRO \\ $25 ' 5 \times 23 \mathrm{~cm}$} \\ Encuadernación: tapa dura. \\ $\mathrm{N}^{\circ}$ de páginas: 40
}

\section{RELACIÓN IMAGEN/TEXTO \\ Complemento}

\section{PROTAGONISTA}

Max, un niño

\section{CONTENIDO}

Sinopsis: Castigado sin cenar por sus travesuras, Max emprende un viaje simbólico desde su habitación hasta un lugar fantástico, atravesando un tiempo/espacio mítico y enfrentándose a sus miedos. Allí llegará a convertirse en el Rey de los monstruos.

Mensaje: el poder de la imaginación y los lugares a los que puede llevarte.

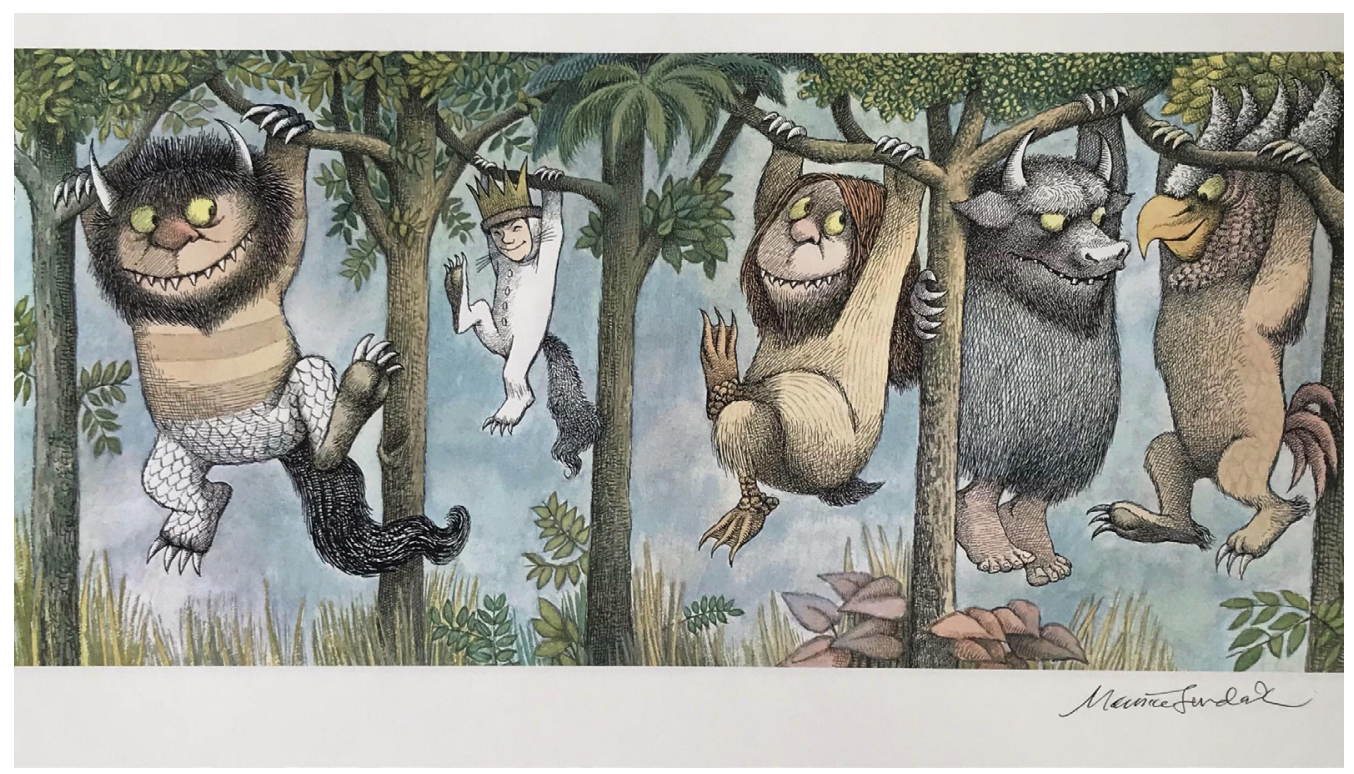


3b. Audiovisual: Where the wild things are. Spike Jonze, 2009

\section{REGISTRO \\ Título: Donde viven los monstruos \\ Director: Spike Jonze \\ Guion: Spike Jonze, Dave Eggers \\ Productora: Warner Bros. Pictures / Legendary Pictures / Village Roads- how / Playtone \\ Año de estreno: 2009 \\ País: Estados Unidos \\ Público objetivo: a partir de 9 años \\ Duración: 101 minutos \\ GÉNERO \\ Fantástico, aventuras, drama \\ TÉCNICA \\ Imagen real, actores reales. Mario- netas y "projection mapping" para los monstruos \\ FORMATO \\ Largometraje}

\section{CONTENIDO}

Sinopsis: Cuando Max, un niño desobediente, es enviado a la cama sin cenar, se zambulle en un mundo imaginario creado por él y que está poblado por feroces criaturas que le obedecen ciegamente.

\section{ADAPTACIÓN}

La película es más inquietante que el álbum, jugando más con la idea de Max en la tierra de los monstruos y su relación con cada uno de estos seres, que responde a su relación con gente de su entorno real. Max plasma en ese mundo imaginario todos sus problemas reales. Al ser una película de más de hora y media, el álbum solo está presente como idea de la que parten.

Se trata más bien de una recreación ya que el tema y el tono son muy diferentes.

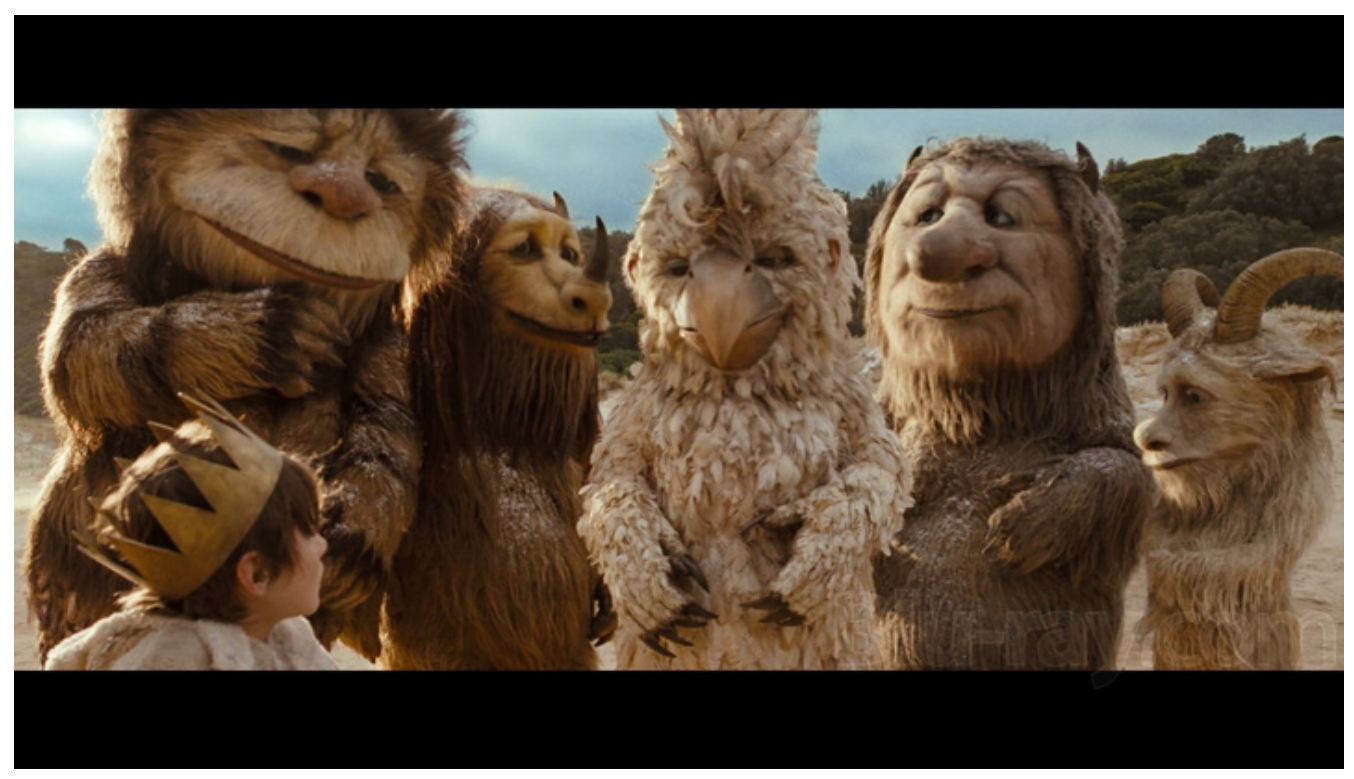


4a. Libro: The Polar Express.

Chris Van Allsburg, 1985

\section{REGISTRO \\ Título: El expreso polar \\ Autor: Chris Van Allsburg \\ Año de publicación: 1985 \\ Editorial: Houghton Mifflin \\ Público objetivo: 6-8 años \\ GÉNERO \\ Fantástico, realismo mágico \\ ILUSTRACIÓN}

Técnica: Ilustraciones muy detalladas con pasteles al óleo.

Iconicidad: hiperrealista

Transmite: misterio, un cierto lirismo

\section{FORMATO \\ Álbum ilustrado}

\section{TAMAÑO DEL LIBRO}

$29 \times 23 \mathrm{~cm}$

Encuadernación: tapa dura.

$\mathrm{N}^{\circ}$ de páginas: 32

\section{RELACIÓN IMAGEN/TEXTO \\ Complemento}

PROTAGONISTA

El narrador, un niño

\section{CONTENIDO}

Sinopsis: En la noche de Navidad, un niño espera en su cama, atento al sonido de cascabeles que anuncia la llegada del trineo de San Nicolás. Muy tarde, otros ruidos lo sorprenden: los resoplidos de vapor y el chirriar de metales de un tren que se ha detenido frente a su casa. A la señal del conductor, el niño sube abordo e inicia un viaje maravilloso al Polo Norte.

Mensaje: En navidad los sueños pueden cumplirse

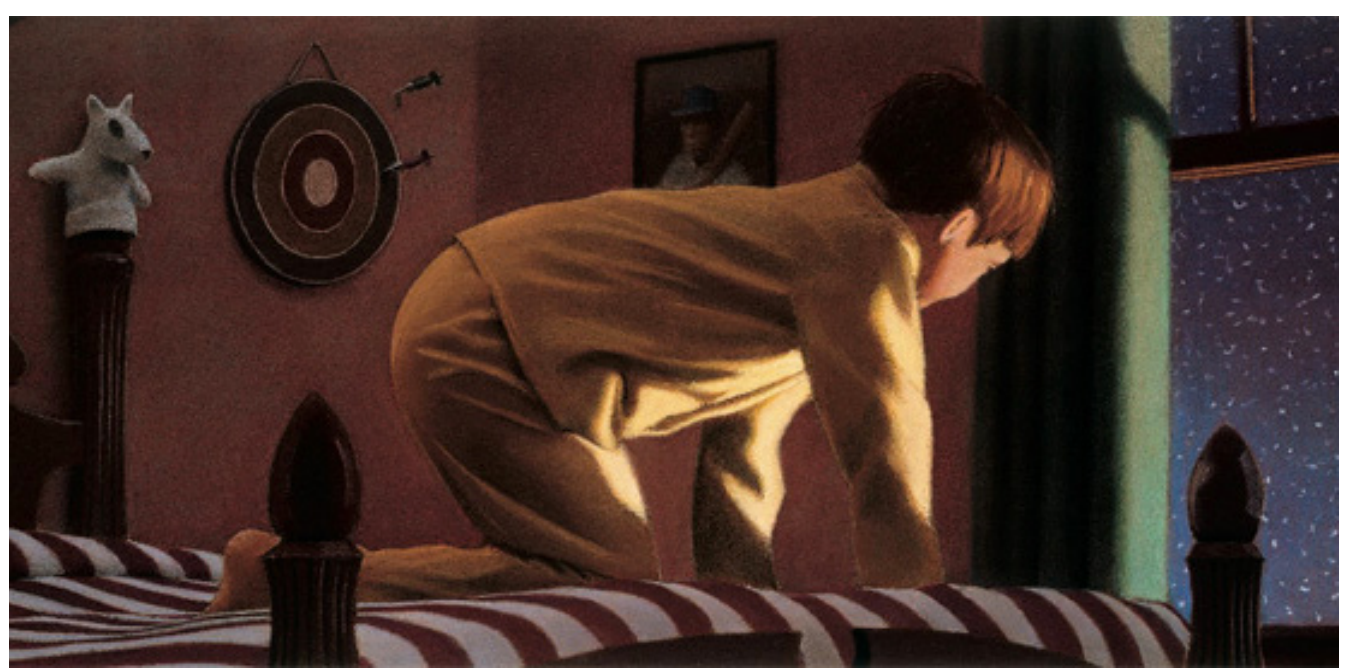




\title{
4b. Audiovisual: The Polar Express. \\ Robert Zemeckis, 2004
}

\author{
REGISTRO \\ Título: Polar Express (El expreso po- \\ lar) \\ Director: Robert Zemeckis \\ Guion: Robert Zemeckis, William \\ Broyles Jr \\ Productora: Warner Bros. Pictures / \\ Castle Rock Entertainment presen- \\ tan una producción Playtone / Ima- \\ gemovers / Golden Mean \\ Año de estreno: 2004 \\ País: Estados Unidos \\ Público objetivo: a partir de 10 años \\ Duración: 97 minutos

\section{GÉNERO \\ Fantástico, aventuras, drama}
TÉCNICA
Animación CGI a partir de actores reales con "projection mapping"

\section{FORMATO \\ Largometraje}

\section{CONTENIDO \\ Sinopsis: En una nevada noche de Navidad, un niño emprende un ex- traordinario viaje en tren hacia el Polo Norte. A partir de ese momento empieza una aventura que le servirá para conocerse a sí mismo y que le enseñará que la magia puede estar siempre presente en la vida a condi- ción de creer en ella.}

\section{ADAPTACIÓN}

La estructura de la película es más compleja, las ilustraciones hiperrealistas se traducen al 3D que roza el "valle inquietante", el libro es más poético y enigmático, mientras que el film encaja más en aventuras y acción.

Tema semejante y tono diferente.

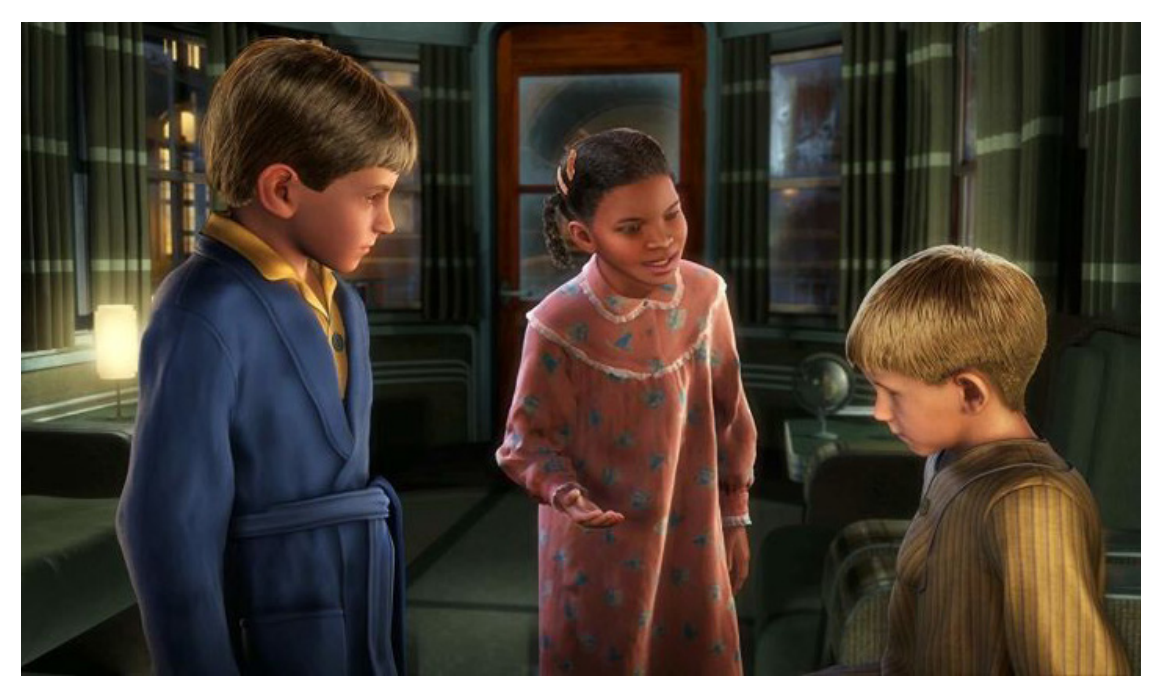


5a. Libro: A day with Wilbur Robinson. William Joyce, 1990

\author{
REGISTRO \\ Título: Un día con Wilbur Robinson \\ Autor: William Joyce \\ Año de publicación: 1990 \\ Editorial: Harper Trophy \\ Público objetivo: 4-8 años

\section{GÉNERO} \\ Fantástico
}

\section{ILUSTRACIÓN}

Técnica: Dibujos a gouache Iconicidad: caricatura realista

Transmite: un hogar loco e idílico que mezcla el ambiente de la década de los 40 americana con un aire futurista

\section{FORMATO \\ Álbum ilustrado}

\section{TAMAÑO DEL LIBRO}

$29 \times 23 \mathrm{~cm}$

Encuadernación: tapa dura.

$\mathrm{N}^{\circ}$ de páginas: 40

\section{RELACIÓN IMAGEN/TEXTO}

Complemento y en ciertos momentos contrapunto

\section{PROTAGONISTA}

El narrador y su mejor amigo Wilbur Robinson, aunque se podría decir que toda la familia es la protagonista

\section{CONTENIDO}

Sinopsis: Un niño y su amigo Wilbur visitan a la inusual familia de este último en su casa. Mientras pasan el día con los Robinson, emprenden la búsqueda de los dientes falsos de su bisabuelo y se van encontrando a sus disparatados familiares, cada cual más increíble que el anterior, pasando por robots, ranas que cantan y viajes en el tiempo.

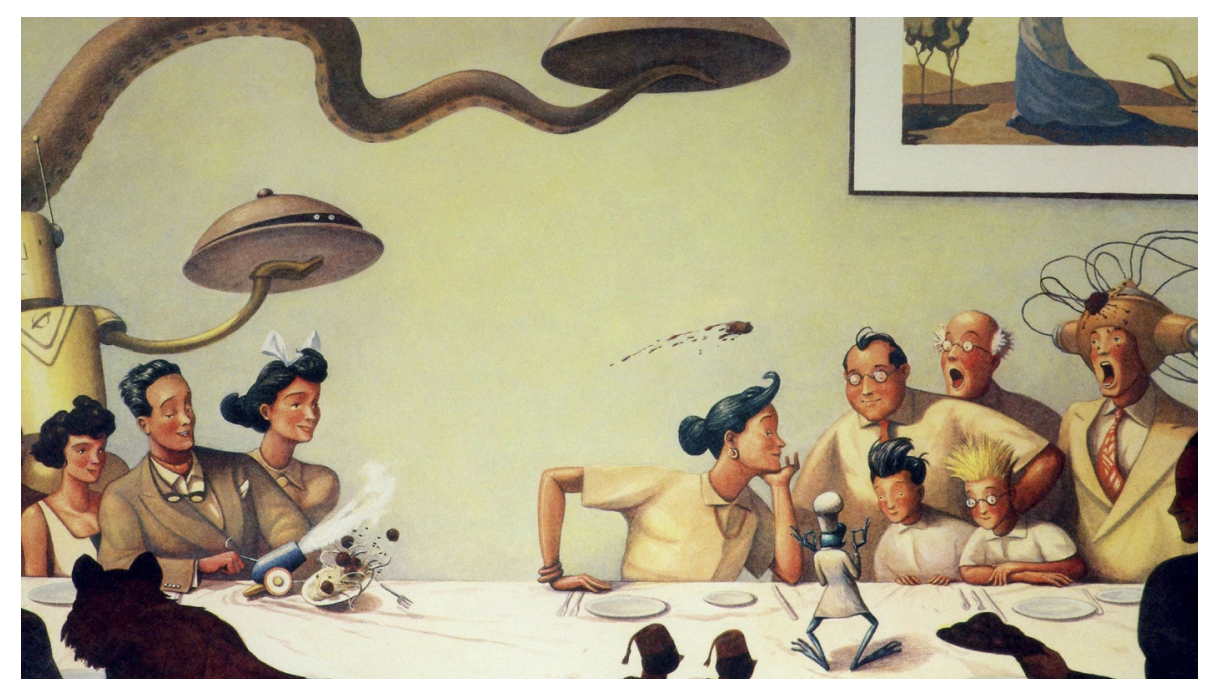


5b. Audiovisual: Meet the Robinsons. Stephen J. Anderson, 2007

\section{REGISTRO \\ Título: Conociendo a los Robinsons \\ Director: Stephen J. Anderson \\ Guion: Michelle Bochner \\ Productora: Walt Disney Pictures / \\ Walt Disney Animation Studios \\ Año de estreno: 2007 \\ País: Estados Unidos \\ Público objetivo: a partir de 6 años \\ Duración: 102 minutos}

\section{GÉNERO \\ Ciencia ficción, aventuras}

\section{TÉCNICA \\ Animación 3D \\ FORMATO \\ Largometraje}

\section{PROTAGONISTA}

Lewis es el protagonista de la historia, y de forma secundaria Wilbur Robinson

\section{CONTENIDO}

Sinopsis: Cuando Lewis conoce a un misterioso chico que viene del futuro llamado Wilbur Robinson, ambos harán un viaje en el tiempo donde Lewis conoce a la familia Robinson. Son perseguidos por un misterioso hombre malvado y su bombín mientras tratan de arreglar el pasado sin alterar el futuro.

\section{ADAPTACIÓN}

Mantiene el humor, los personajes y la estética inusual y loca de la familia Robinson, pero el tema es radicalmente diferente, incluso la relación de los dos protagonistas es distinta, ya que en el libro son mejores amigos y en la película acabamos descubriendo que se trata de padre e hijo. Esta versión se lanza de lleno en el tema de los viajes en el tiempo mientras que en el álbum solo es otra de las locuras de la casa de la familia Robinson. También tenemos un antagonista para los dos chicos protagonistas. Igual que en el libro el espectador empatiza especialmente con Lewis, al ser la persona (a priori) ajena a la familia.

Tema diferente y tono semejante.

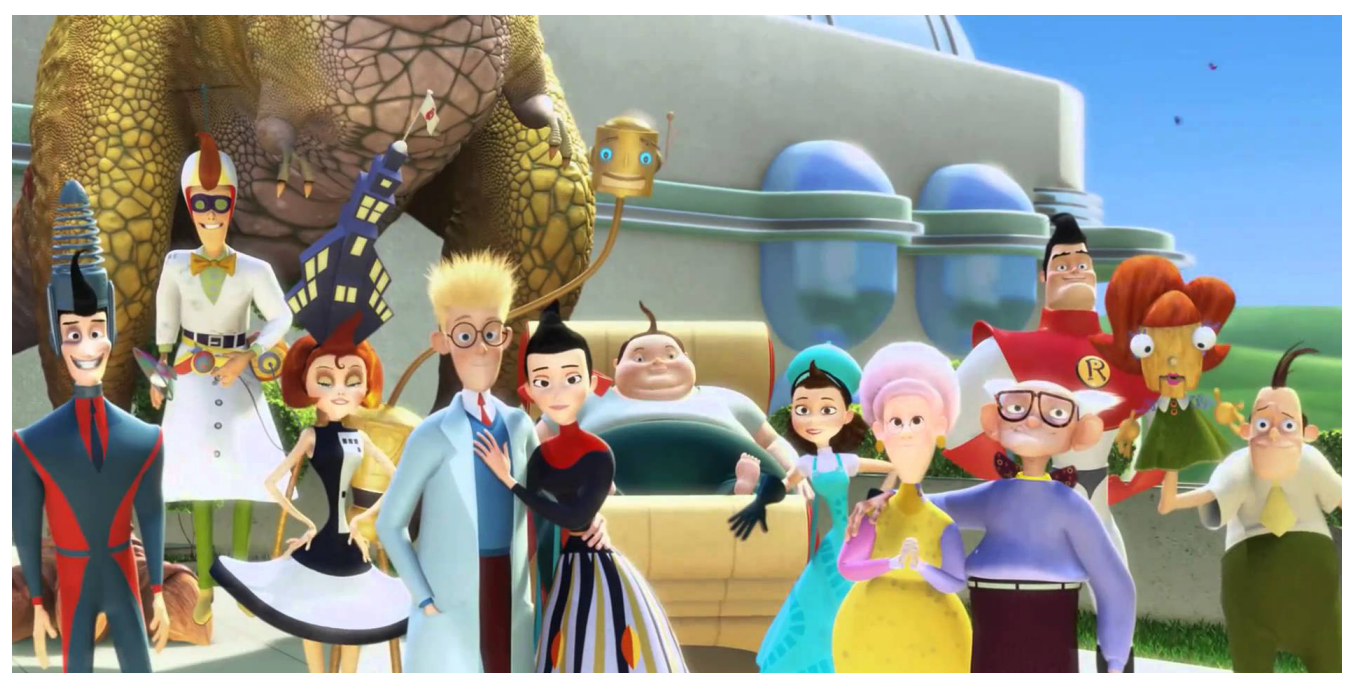


6a. Libro: Shrek!

William Steig, 1990

\section{REGISTRO}

Título: ¡Shrek!

Autor: William Steig

Año de publicación: 1990

Editorial: Farrar, Straus and Giroux

Público objetivo: 5-8 años

GÉNERO

Fantástico

\section{ILUSTRACIÓN}

Técnica: Dibujos de línea a tinta sueltos, "cartoony", descabellados. Coloreados de forma plana Iconicidad: caricatura

Transmite: humor y despreocupación

\section{FORMATO}

Libro-Álbum ilustrado

\section{TAMAÑO DEL LIBRO}

$21 \times 28 \mathrm{~cm}$

Encuadernación: tapa dura.

$\mathrm{N}^{\circ}$ de páginas: 26 / 32
RELACIÓN IMAGEN/TEXTO

Complemento, las ilustraciones dejan mucho a la imaginación

PROTAGONISTA

Shrek, un ogro

CONTENIDO

Sinopsis: Shrek, un ogro contracultural, feo y malhumorado, recorre el mundo en busca de aventura encontrándose con asnos, brujas, caballeros, dragones, finalmente con una princesa tan horrible y adorable como él.

Mensaje: aceptarse y mantenerse fiel a uno mismo

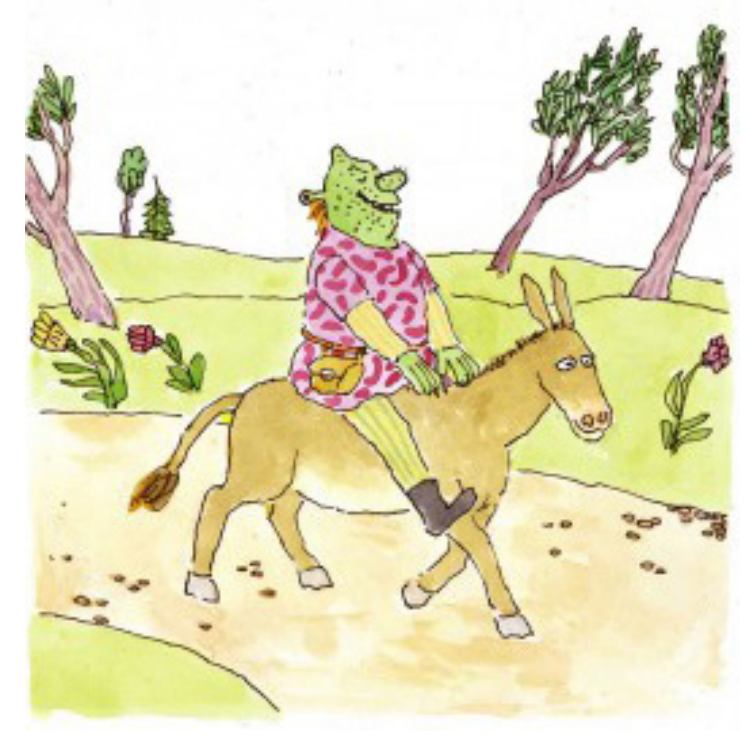


6b. Audiovisual: Shrek.

\section{Andrew Adamson y Vicky Jenson, 2001}

\author{
REGISTRO \\ Título: Shrek \\ Director: Andrew Adamson, Vicky \\ Jenson \\ Guion: Ted Elliott, Terry Rossio, Da- \\ vid N. Weiss, Roger S.H. Schulman \\ Productora: DreamWorks Animation \\ / DreamWorks SKG / Pacific Data \\ Images (PDI) \\ Año de estreno: 2001 \\ País: Estados Unidos \\ Público objetivo: a partir de 4-6 años \\ Duración: 87 minutos
}

\section{GÉNERO \\ Comedia, aventuras, fantástico, pa- rodia}

\section{TÉCNICA}

Animación 3D

\section{FORMATO \\ Largometraje}

\section{PROTAGONISTA}

Shrek es el proncipal protagonista pero como importantes secundarios están Burro y Fiona

\section{CONTENIDO}

Sinopsis: Hace mucho tiempo, en una lejanísima ciénaga, vivía un feroz ogro llamado Shrek.
De repente, un día, su soledad se ve interrumpida por una invasión de sorprendentes personajes. Hay ratoncitos ciegos en su comida, un enorme y malísimo lobo en su cama, tres cerditos sin hogar y otros seres que han sido deportados de su tierra por el malvado Lord Farquaad. Para salvar su territorio, Shrek hace un pacto con Farquaad y emprende viaje para conseguir que la bella princesa Fiona acceda a ser la novia del Lord. En tan importante misión le acompaña un divertido burro, dispuesto a hacer cualquier cosa por Shrek: todo, menos guardar silencio.

Mensaje: el amor nos hace bellos, aceptación social

\section{ADAPTACIÓN}

Mantiene el humor intertextual del libro, levándolo a su máximo exponente. Los personajes planos del libro adquieren complejas personalidades. Shrek tiene una misión que ocupa la mayor parte de la trama y no aparece en el libro. Además se juega con la aparición de muchos personajes conocidos dentro de la cultura popular, como el Lobo Feroz, el Hada Madrina, etc.

Tema diferente y tono semejante.

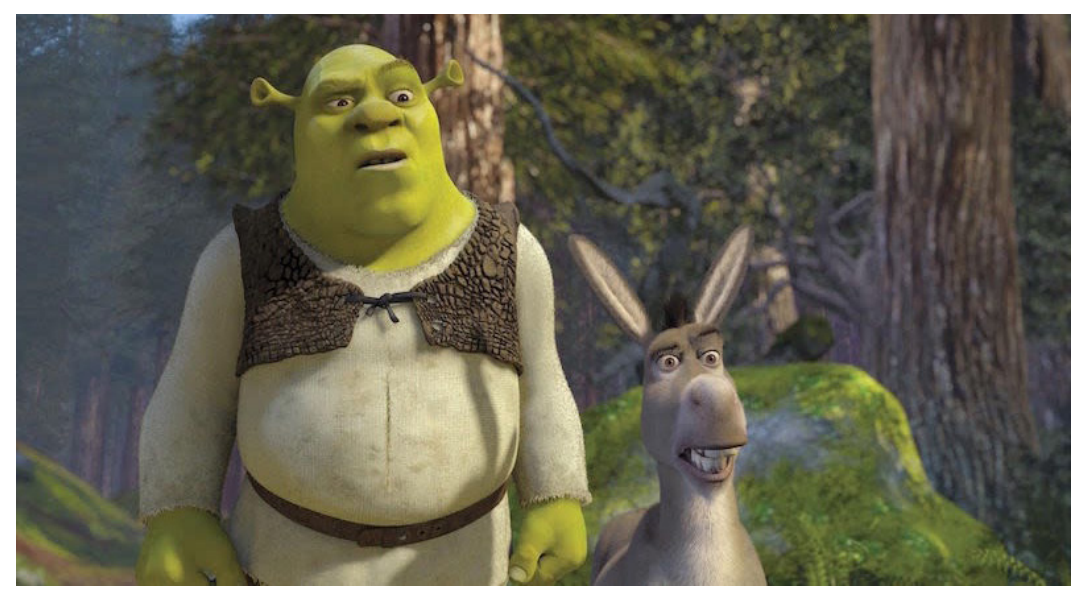


7a. Libro: The Gruffalo. Julia Donaldson, Axel Scheffler, 1999

\author{
REGISTRO \\ Título: El Grúfalo \\ Autor: Julia Donaldson, Axel Sche- \\ ffler \\ Año de publicación: 1999 \\ Editorial: Macmillan \\ Público objetivo: a partir de 3 años \\ GÉNERO \\ Fantástico

\section{ILUSTRACIÓN} \\ Técnica: Dibujos sueltos a tinta pin- \\ tados con acuarela y lápices de colo- \\ res muy vivos \\ Iconicidad: caricatura de animales \\ Transmite: viveza, energía

\section{FORMATO \\ Álbum ilustrado}

\section{TAMAÑO DEL LIBRO \\ $21^{\prime} 60 \times 27 \mathrm{~cm} / 28 \times 24 \mathrm{~cm}$ \\ Encuadernación: tapa dura. \\ $\mathrm{N}^{\circ}$ de páginas: 32}

\section{RELACIÓN IMAGEN/TEXTO \\ Complemento}

\section{PROTAGONISTA}

Un ratoncito

\section{CONTENIDO}

Sinopsis: Un pequeño ratoncito se adentra en el peligroso bosque y gracias a su astucia e inteligencia, consigue ahuyentar a todos los que quieren comérselo. ¿Que cómo lo hace? Sólo tiene que hablarles un poco de su amigo El Grúfalo...

Mensaje: el tamaño no está reñido con la inteligencia ni con la capacidad de sobreponerse ante los peligros

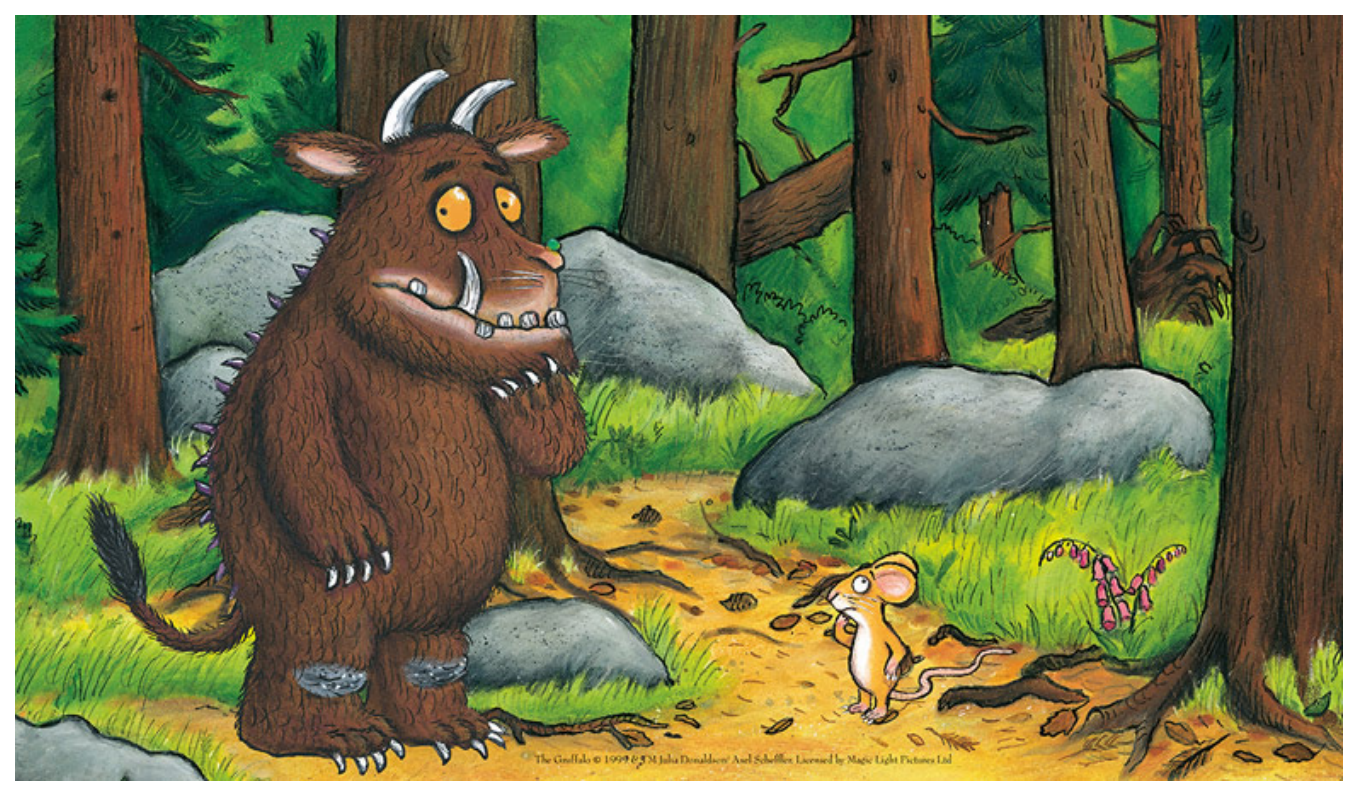


7b. Audiovisual: The Gruffalo.

Max Lang, Jakob Schuh, 2009

$\begin{array}{ll}\text { REGISTRO } & \\ \text { Título: El Grúfalo } & \text { TÉCNICA } \\ \text { Director: Max Lang, Jakob Schuh } & \text { Animación 3D } \\ \text { Guion: Julia Donaldson, Jakob } & \\ \begin{array}{l}\text { Schuh, Max Lang } \\ \text { Productora: Magic Light Pictures / }\end{array} & \text { FORMATO } \\ \text { Studio Soi / British Broadcasting Cor- } & \\ \text { poration (BBC) } & \text { ADAPTACIÓN } \\ \text { Año de estreno: } 2009 & \text { Mantiene la estética del cuento y si- } \\ \text { País: Reino Unido } & \text { gue la misma narrativa pero de for- } \\ \text { Público objetivo: a partir de } 3 \text { años } & \text { ma más pausada. } \\ \text { Duración: } 27 \text { minutos } & \text { Tema y tono semejante. }\end{array}$

GÉNERO

Comedia, infantil, fantástico

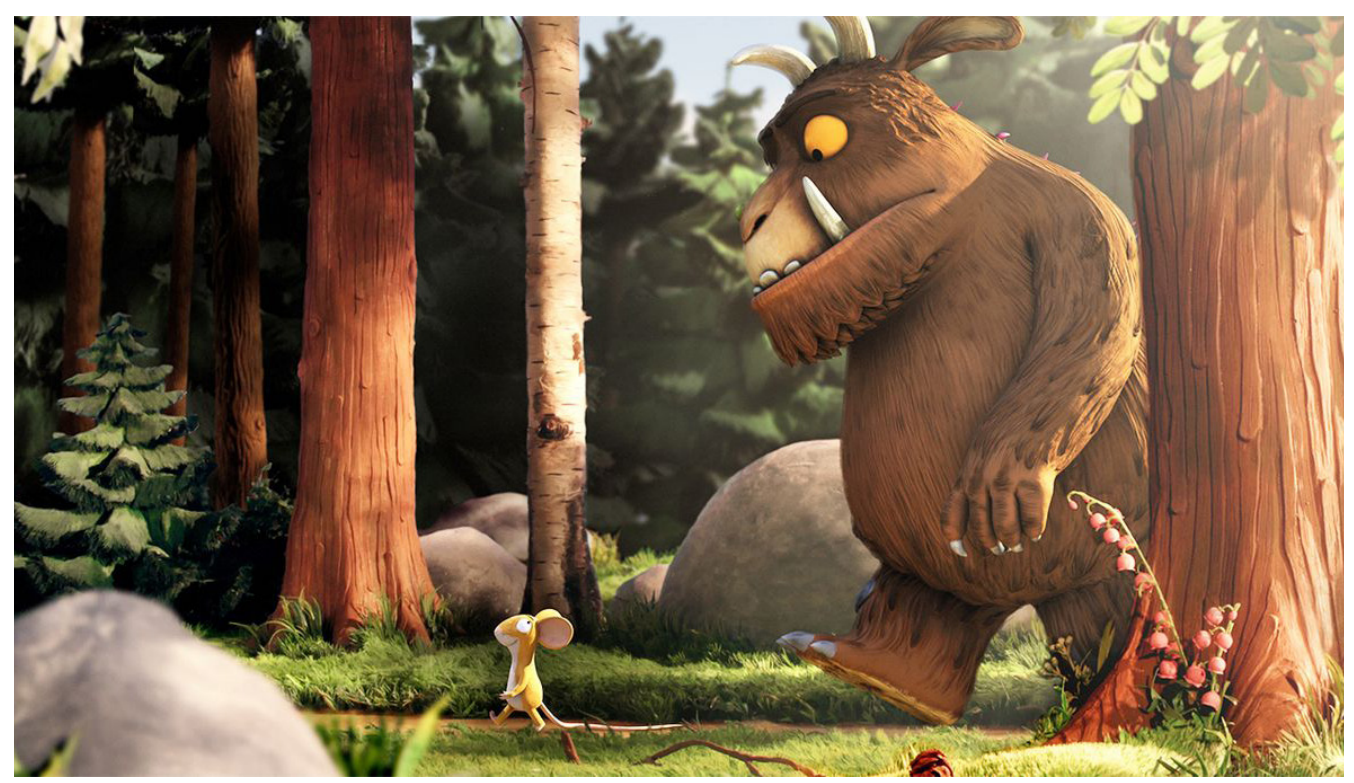


8a. Libro: Cloudy with a chance of meatballs. Judi \& Ron Barrett, 1978

\section{REGISTRO}

Título: Nublado con probabilidades de albóndigas

Autor: Judi Barrett, Ron Barrett

Año de publicación: 1978

Editorial: Simon \& Schuster

Público objetivo: 4-8 años

\section{GÉNERO}

Fantástico

\section{ILUSTRACIÓN}

Técnica: Dibujo muy detallado a tinta intrincado con textura y coloreado Iconicidad: caricatura realista Transmite: Recuerda a las tiras de cómics antiguas

\section{FORMATO \\ Libro ilustrado}

\section{TAMAÑO DEL LIBRO \\ $24 \times 21 \mathrm{~cm}$}

Encuadernación: tapa dura.

$\mathrm{N}^{\circ}$ de páginas: 32

\section{RELACIÓN IMAGEN/TEXTO Complemento}

\section{PROTAGONISTA}

El narrador en principio es una niña, pero luego es su abuelo el que cuenta una historia en el que los protagonistas son los habitantes de Tragaycome

\section{CONTENIDO}

Sinopsis: El pequeño pueblo de Tragaycome era, más o menos, como cualquier otro pueblo salvo porque el tiempo cambiaba tres veces al día: en el desayuno, en la comida y en la cena. Allí nunca llovía lluvia, nunca nevaba nieve y el viento nunca soplaba así, sin más. Llovían cosas como sopa y zumo de frutas, nevaba puré de patatas $\mathrm{y}$, a veces, el viento traía grandes tormentas de hamburguesas. La vida en el pueblo era deliciosa, hasta que empezó a empeorar el tiempo. La comida y las porciones eran cada vez más grandes. Tragaycome sufrió inundaciones y tormentas de alimentos gigantes. El pueblo quedó hecho un desastre y todo el mundo temía por sus vidas. Había que hacer algo... y rápido.

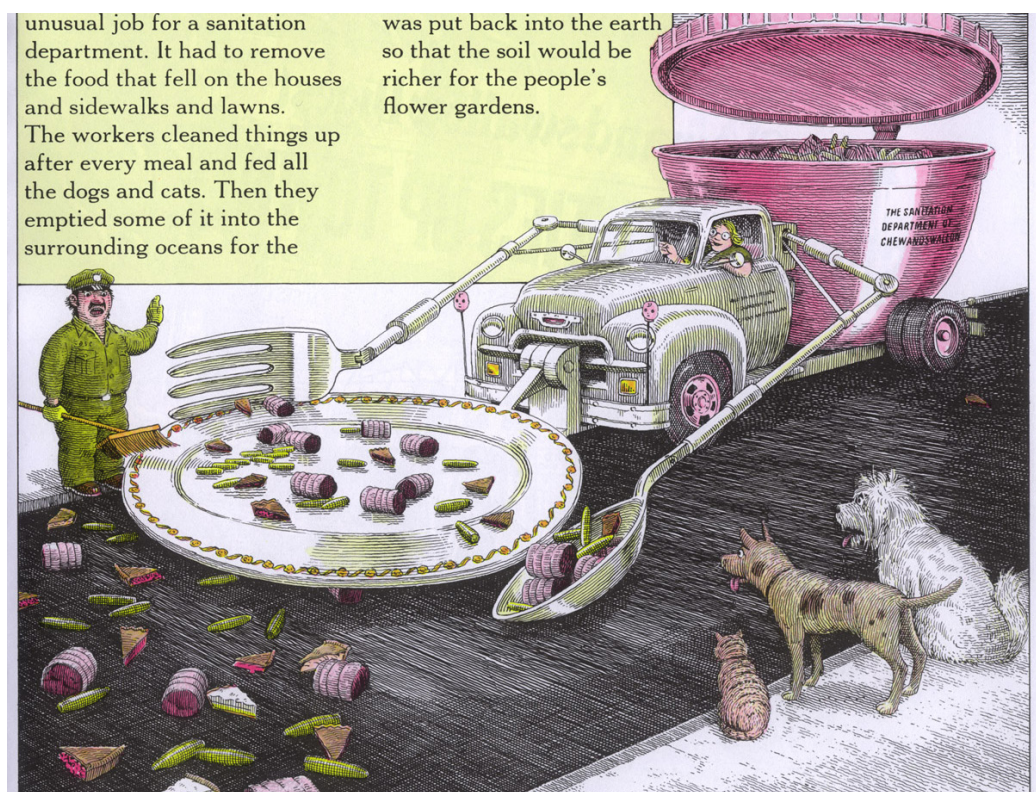


8b. Audiovisual: Cloudy with a chance of meatballs. Chris Miller, Phil Lord, 2009

\section{REGISTRO}

Título: Lluvia de albóndigas

Director: Phil Lord, Christopher Miller

Guion: Phil Lord, Christopher Miller

Productora: Sony Pictures Animation

Año de estreno: 2009

País: Estados Unidos

Público objetivo: a partir de 5 años

Duración: 89 minutos

\section{GÉNERO}

Comedia, infantil, ciencia ficción

\section{TÉCNICA}

Animación 3D

FORMATO

Largometraje

\section{PROTAGONISTA}

Flint, un inventor (no aparece en el álbum)

\section{CONTENIDO}

Sinopsis: Flint Lockwood es un creativo inventor que aspira servir a su comunidad y a que su padre se sienta orgulloso de él.
Su dedicación a la ciencia se verá recompensada cuando descubra cómo transformar el agua en alimentos sólidos... Claro que, todo éxito puede conllevar un riesgo, y Flint se percatará de ello demasiado tarde... Menos mal que en el camino conocerá a Sam Sparks, una deliciosa "chica del tiempo" que se ha desplazado a Aldabas de Mar para retransmitir "el mayor fenómeno meteorológico de la historia".

\section{ADAPTACIÓN}

El estilo del diseño de personajes es muy diferente, no tiene nada que ver con la estética antigua de las ilustraciones.

El tema solo es igual en cuanto a que llueve comida, pero los personajes son totalmente diferentes, no encontramos a un abuelo contando una historia a sus nietso, sino que el protagonista es el inventor que hace que el tiempo sea tan extraño en esa ciudad (algo que en el libro sucede sin explicacióm ni causa) y la historia se centra en sus aventuras.

Tema y tono diferentes.

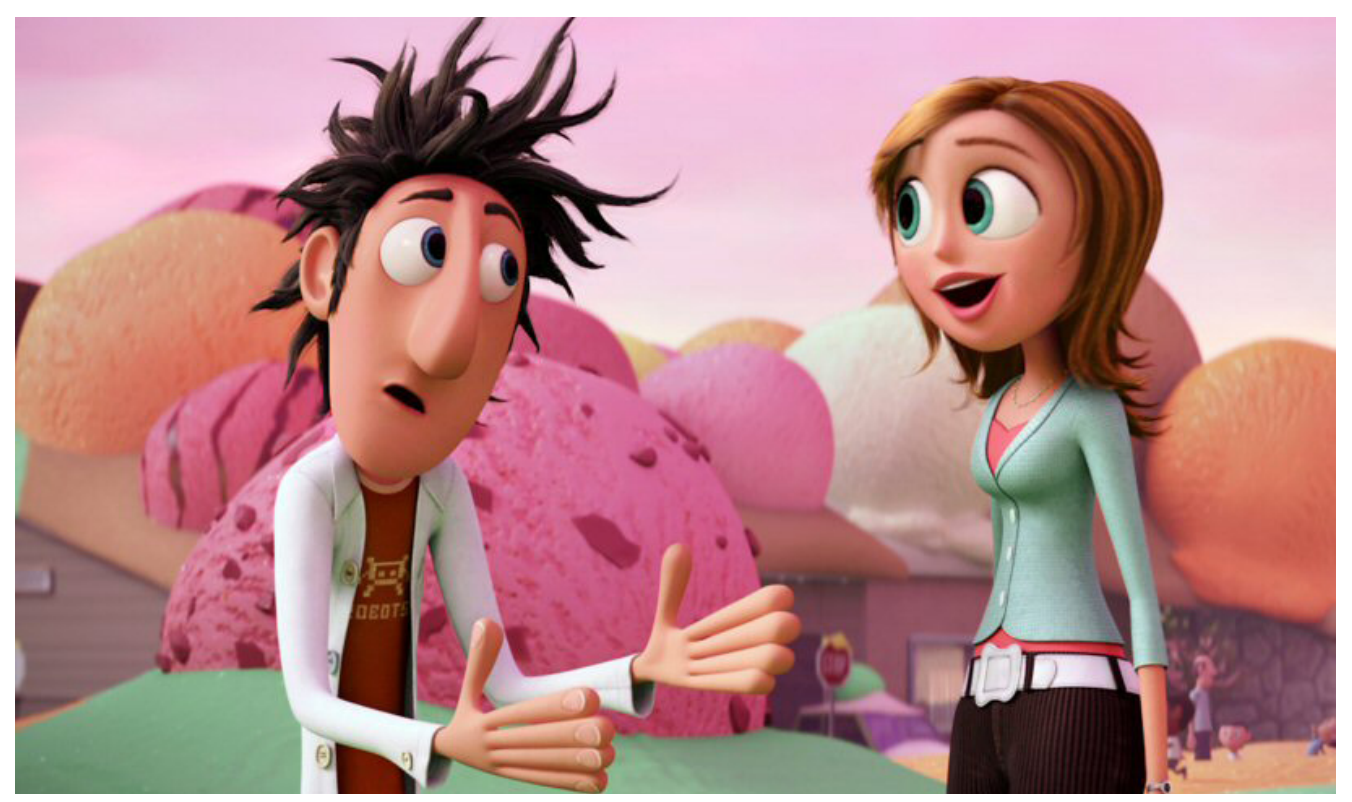


9a. Liibro: The Guardians of Childhood (saga). The man in the moon. William Joyce, 2010

\author{
REGISTRO \\ Título: El origen de los Guardianes \\ (saga). El hombre de la luna \\ Autor: William Joyce \\ Año de publicación: 2011 \\ Editorial: Atheneum Books for Young \\ Readers \\ Público objetivo: a partir de 4-6 años \\ GÉNERO \\ Fantástico

\section{ILUSTRACIÓN} \\ Técnica: Ilustraciones a guache vi- \\ brantes muy elaboradas y coloridas, \\ con volumen \\ Iconicidad: caricatura realista \\ Transmite: fantasía y magia \\ FORMATO \\ Libro ilustrado
}

TAMAÑO DEL LIBRO

$24{ }^{\prime} 4$ × $25^{\prime} 4 \mathrm{~cm}$

Encuadernación: tapa dura.

$\mathrm{N}^{\circ}$ de páginas: 56

\section{RELACIÓN IMAGEN/TEXTO \\ Complemento}

\section{PROTAGONISTA}

MiM, el hombre en la luna

\section{CONTENIDO}

Sinopsis: El Hombre de la Luna no siempre ha sido un hombre, ni siempre ha estado en la Luna. Hace mucho tiempo fue pequeño, hasta que una batalla contra el malvado Sombra, el Rey de las Pesadillas, lo dejó huérfano y le empujó a una aventura que le convertiría en el primer Guardián de la Infancia.

Mensaje: proteger la magia y la ilusión en los niños

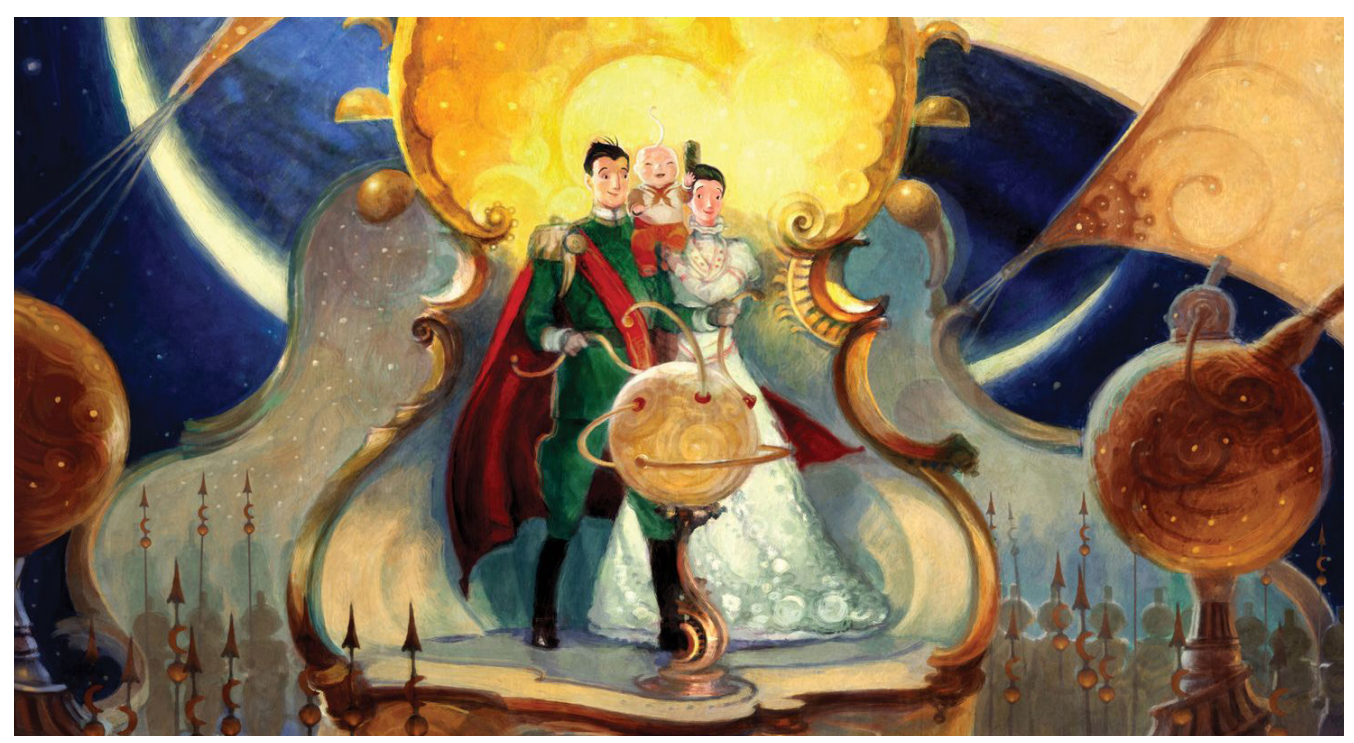


9b. Audiovisual: Rise of the Guardians. Peter Ramsey, 2012

\section{REGISTRO \\ Título: El origen de los guardianes \\ Director: Peter Ramsey \\ Guion: David Lindsay-Abaire \\ Productora: DreamWorks Animation. \\ Productor: Guillermo del Toro \\ Año de estreno: 2012 \\ País: Estados Unidos \\ Público objetivo: a partir de 7 años \\ Duración: 97 minutos}

\section{GÉNERO}

Fantástico, aventuras

TÉCNICA

Animación 3D

FORMATO

Largometraje

\section{PROTAGONISTA}

Jack Frost, uno de los guardianes

\section{CONTENIDO}

Sinopsis: Los guardianes son un grupo de superhéroes inmortales con extraordinarios poderes.
Cuando un espíritu maligno llamado Sombra se propone inundar de miedo los corazones de los niños de todo el mundo, los Guardianes se unen por primera vez para plantarle cara y defender al mundo de su temido enemigo.

\section{ADAPTACIÓN}

La película no se centra en este libro en concreto sino en toda la saga, por lo que aunque el tema de base es el mismo (lucha contra Sombra, mantener la esperanza y la ilusión en los niños), es desarrollo es muy distinto ya que se centra en otro personaje, Jack Frost. Casi todos los demás personajes que aparecen en el libro también lo hacen en la película, excepto MiM, el propio protagonista. El estilo de la animación imita el del libro hasta cierto punto. Se mantiene el mismo espíritu de magia y fantasía.

Tono y tema de base similares, pero distinta historia.

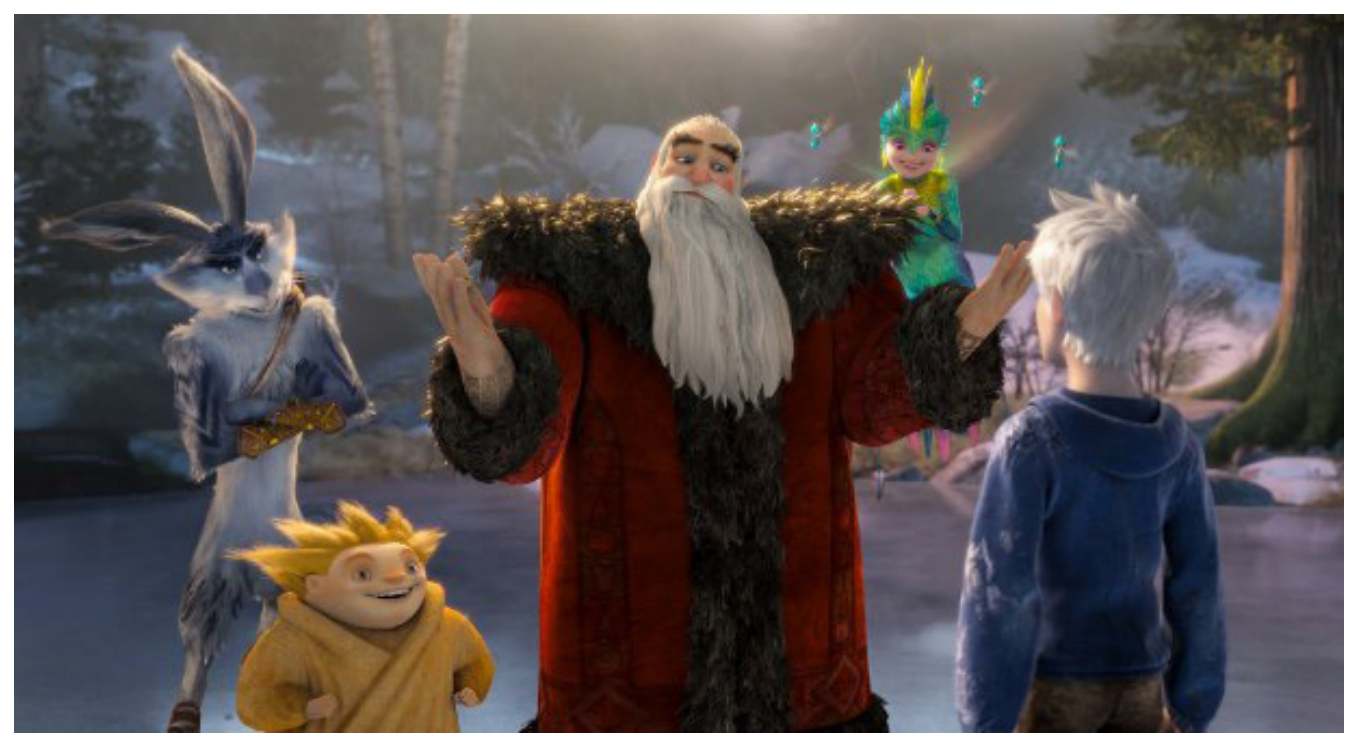


10a. Libro: Horton hears a who.

Dr.Seuss, 1954

\section{REGISTRO}

Título: ¡Horton escucha a Quién!

Autor: Theodor Seuss Geisel

Año de publicación: 1954

Editorial: Random House

Público objetivo: entre 5 y 12 años

\section{GÉNERO}

Fantástico

\section{ILUSTRACIÓN}

Técnica: Dibujo sencillo y suelto a línea, con partes de color plano Iconicidad: caricatura de animales Transmite: humor, ligereza

\section{FORMATO}

Libro ilustrado

\section{TAMAÑO DEL LIBRO}

$21 \times 28 \mathrm{~cm}$

Encuadernación: tapa dura.

$\mathrm{N}^{\circ}$ de páginas: 72

\section{RELACIÓN IMAGEN/TEXTO \\ Complemento}

\section{PROTAGONISTA}

Horton el elefante

\section{CONTENIDO}

Sinopsis: Horton el elefante encuentra un trébol habitado por una sociedad de seres microscópicos conocidos como los quiénes y decide dedicar todo su tiempo a atender las necesidades de los quiénes y a protegerlos de los peligros de un mundo mucho más grande.

Mensaje: Una persona es persona por pequeña que sea

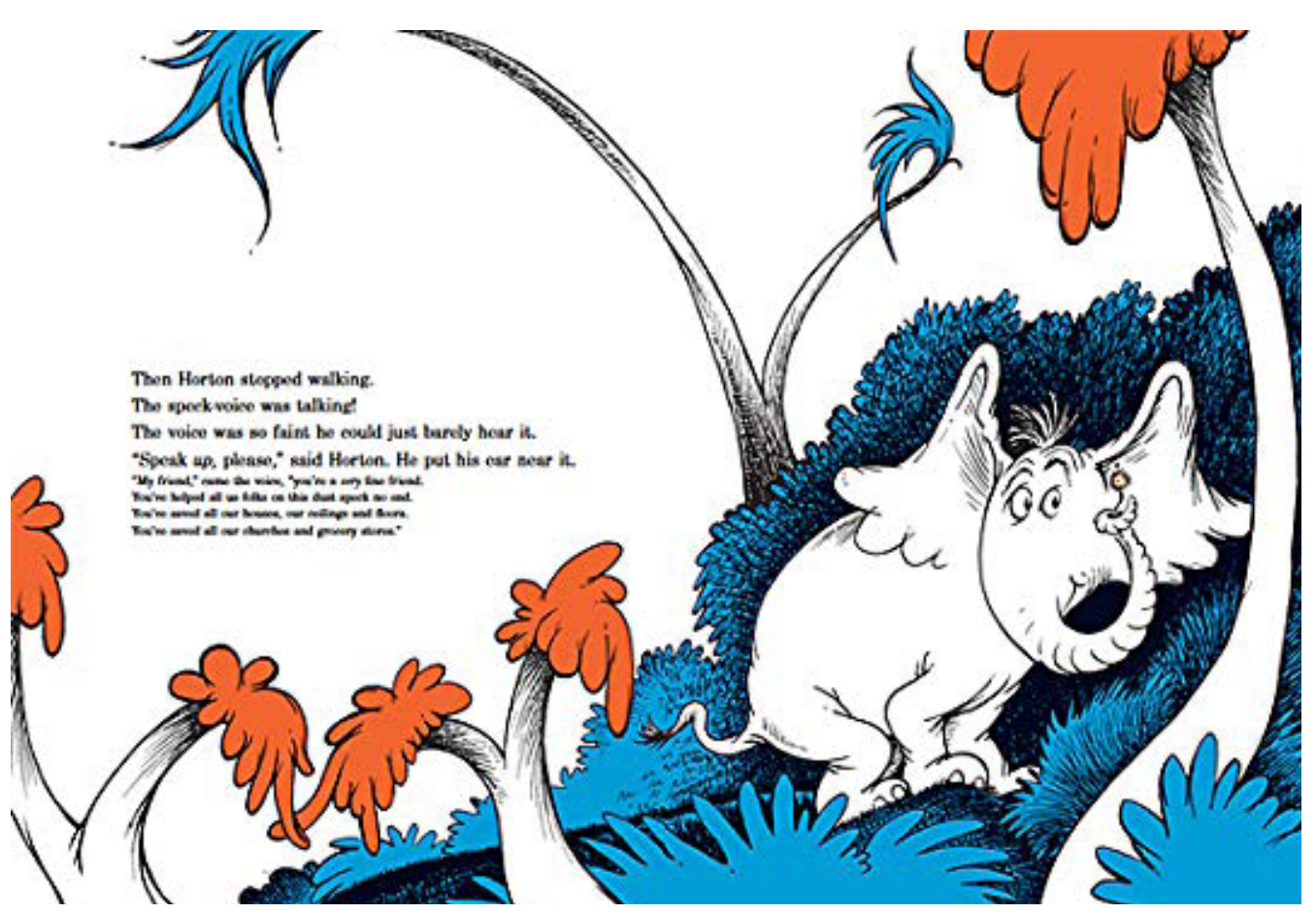


10b. Audiovisual: Horton. Jimmy Hayward, Steve Martino, 2008

\section{REGISTRO \\ Título: Horton Hears a Who! \\ Director: Jimmy Hayward, Steve \\ Martino \\ Guion: Ken Daurio, Cinco Paul \\ Productora: 20th Century Fox / Blue \\ Sky Studios \\ Año de estreno: 2008 \\ País: Estados Unidos \\ Público objetivo: a partir de 4 años \\ Duración: 88 minutos}

\section{GÉNERO}

Comedia, aventuras

TÉCNICA

Animación 3D

FORMATO

Largometraje

\section{CONTENIDO}

Sinopsis: Historia de un elefante que es el único animal capaz de escuchar señales de vida provenientes de una mota de polvo. El resto de animales creen que está loco y quieren destruir la mota de polvo. Pero Horton se mantiene en defensa del pequeño poblado...

\section{ADAPTACIÓN}

Tema similar. El tono se mantiene aunque sin la poesía del cuento. Estilo de Seuss transformado para la animación por ordenador.

Tema similar y tono diferentes.

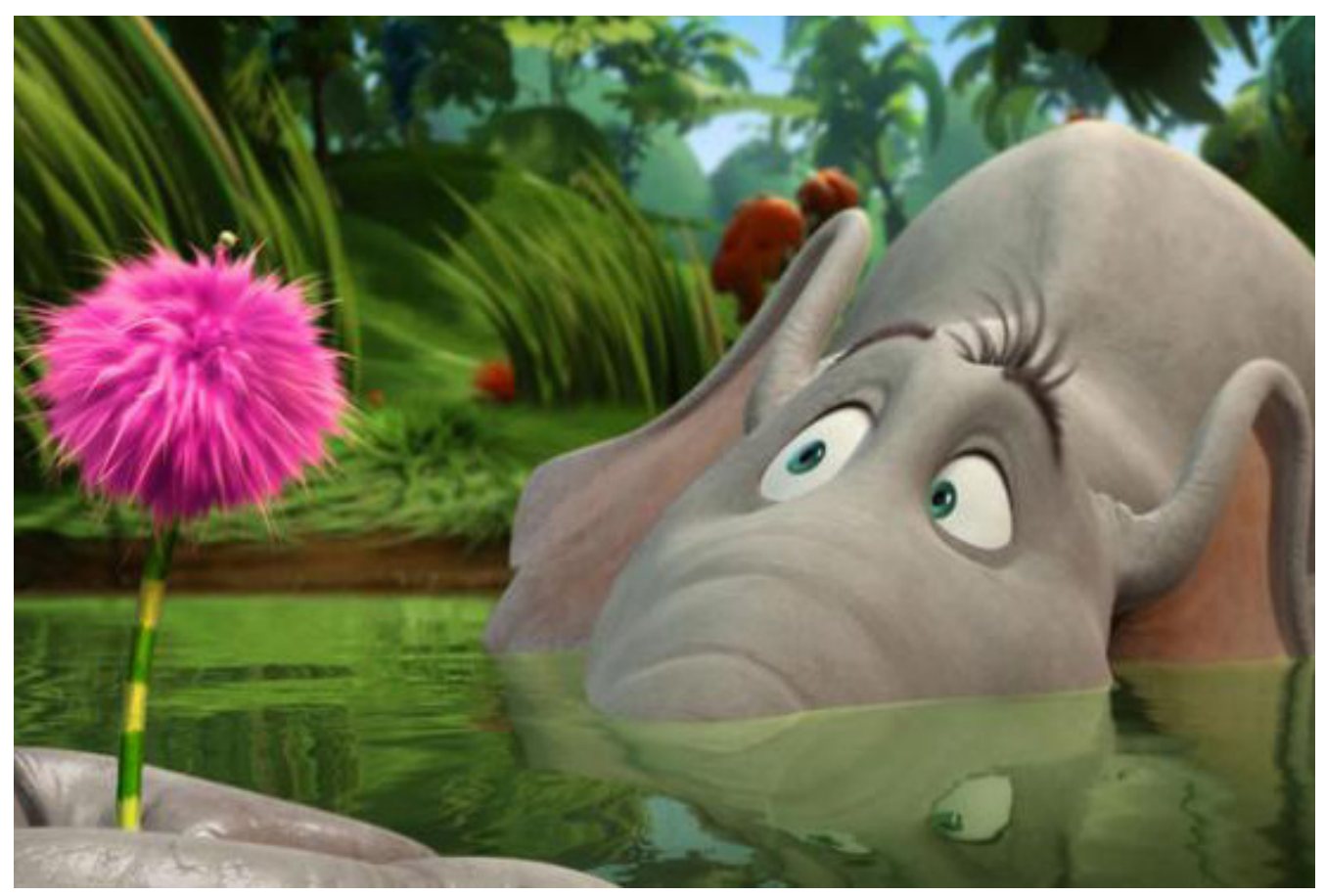


11a. Libro: The fantastic flying books of Mr. Morris Lessmore.

William Joyce, 2011

\section{REGISTRO \\ Título: Los fantásticos libros volado- res del sr. Morris Lessmore \\ Autor: William Joyce, colaboración con Joe Bluhm \\ Año de publicación: 2012 \\ Editorial: Simon \& Schuster. Athe- neum \\ Público objetivo: entre 6 y 9 años \\ GÉNERO \\ Fantástico}

\section{ILUSTRACIÓN}

Técnica: Mezcla ilustraciones en blanco y negro y elaborados dibujos a color con técnica opaca

Iconicidad: realista

Transmite:

\section{FORMATO \\ Álbum ilustrado \\ ${ }^{*}$ Este es un caso excepcional ya que, si bien el álbum inspiró el cor- tometraje, fue este último el que se estrenó primero (cuentan con el mis- mo autor), a la vez que una app in- teractiva}

TAMAÑO DEL LIBRO

$21^{\prime} 4$ × 30'7 cm

Encuadernación: tapa dura.

$\mathrm{N}^{\circ}$ de páginas: 56

\section{RELACIÓN IMAGEN/TEXTO \\ Complemento}

\section{PROTAGONISTA}

Mr. Morris Lessmore

\section{CONTENIDO}

Sinopsis: El escritor Morris Lessmore es transportado por un huracán a un mundo muy particular, justo donde vive el libro que está escribiendo en ese momento. Allí conocerá otros maravillosos libros voladores, de los que cuidará hasta su vejez. Cuando por fin termina de escribir su libro, lo deja junto a los demás libros y se aleja volando él también.

Mensaje: Defensa de la lectura literaria

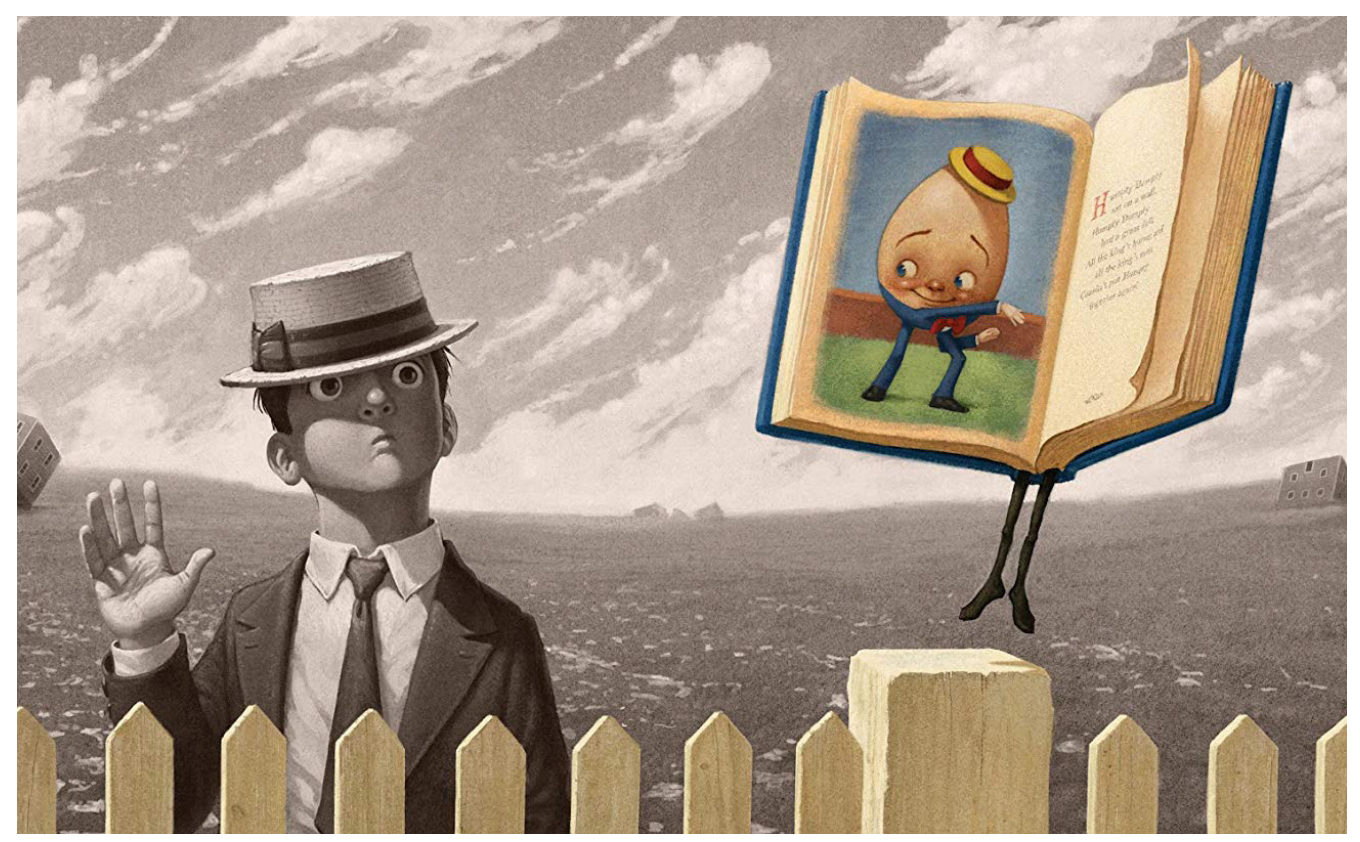


11b. Audiovisual: The fantastic flying books of Mr Morris Lessmore. William Joyce, Brandon Oldenburg, 2011

\section{REGISTRO}

Título: Los fantásticos libros voladores del Sr. Morris Lessmore

Director: William Joyce, Brandon OIdenburg

Guion: William Joyce

Productora: Moonbot Studios

Año de estreno: 2011

País: Estados Unidos

Público objetivo: a partir de 6 años

Duración: 15 minutos

Audio: música, sin diálogo

\section{GÉNERO}

Drama, aventuras, fantástico

\section{TÉCNICA}

Mezcla miniaturas hechas a mano, animación por ordenador 3D, animación en 2D. Juego con el blanco y negro y el color

\section{FORMATO}

Cortometraje

\section{ADAPTACIÓN}

La animación se entretiene más en la acción, en el juego visual. Las ilustraciones mantienen el estilo del cortometraje.

Tema y tono idénticos.

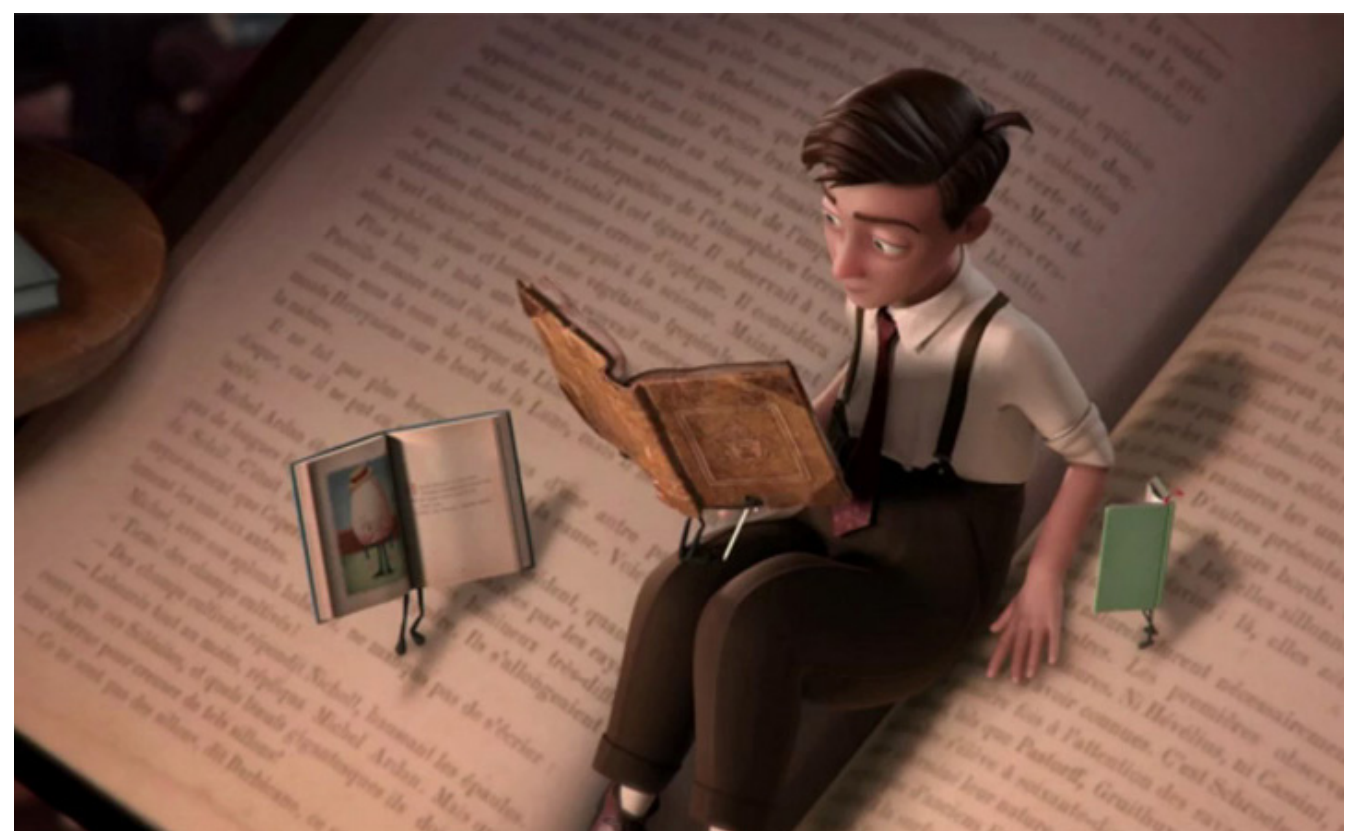


12a. Libro: Winnie the Pooh.

A. A. Milne, E. H. Shepard, 1926

\author{
REGISTRO \\ Título: Winnie the Pooh \\ Autor: A. A. Milne, E. H. Shepard \\ Año de publicación: 1926 \\ Editorial: Methuen \& Co. Ltd. \\ Público objetivo: niños a partir de 8 \\ años
}

\section{GÉNERO \\ Realismo mágico}

\section{ILUSTRACIÓN}

Técnica: línea seguras y ligeras a tinta, coloreado a acuarela

Iconicidad: dibujos sencillos realistas, animales suaves de peluche Transmite: ternura. Su diseño y presentación, sin marco y con una disposición informal dentro, fuera y alrededor del texto, era inusual en su tiempo y constituyó toda una novedad en el campo de la ilustración de los libros infantiles

\section{FORMATO \\ Libro ilustrado}

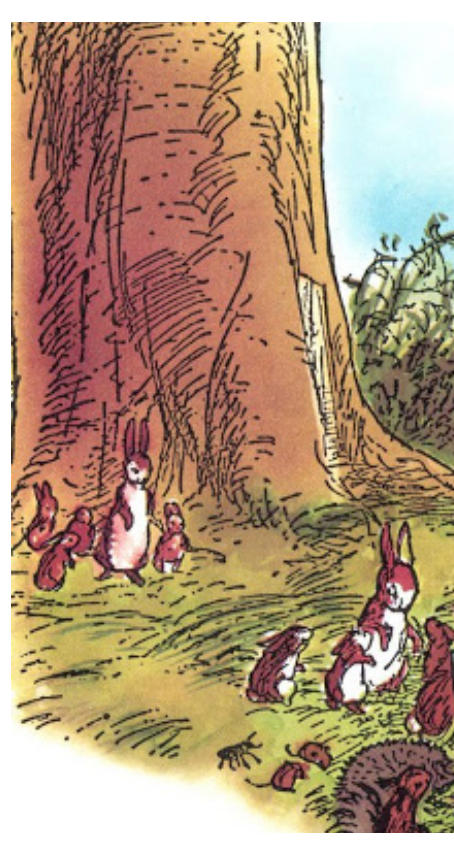

TAMAÑO DEL LIBRO

$14 \times 21 \mathrm{~cm}$. Vertical

Encuadernación: tapa dura. Cartoné $\mathrm{N}^{\circ}$ de páginas: 176

\section{RELACIÓN IMAGEN/TEXTO Complemento}

\section{PROTAGONISTA}

Christopher Robin y sus animales de peluche, sobre todo Winnie the Pooh

\section{CONTENIDO}

Sinopsis: los sentimientos de un niño (Christopher Robin) cuyos animales de peluche (encabezados por el osito Winnie) cobran vida. Las diversas personalidades y temperamentos representados en cada uno de los personajes exponen al niño a una gran riqueza y diversidad de relaciones personales, haciendo claro hincapié en la amistad, todo ello bajo un toque de humor suavemente irónico y delicioso.

Mensaje: la amistad, el compañerismo y la generosidad. 
12b. Audiovisual: Winnie the Pooh. John Lounsbery, Wolfgang Reitherman, 1977

\section{REGISTRO}

Título: Lo mejor de Winnie the Pooh Director: Wolfgang Reitherman, John Lounsbery

Guion: (Libros: A.A. Milne)

Productora: Walt Disney

Año de estreno: 1977

País: Estados Unidos

Público objetivo: niños de 2 a 7 años

Duración: 71 minutos

Audio: canciones, diálogos

\section{GÉNERO}

Ficción, aventuras

\section{TÉCNICA}

Animación tradicional 2D

\section{FORMATO}

Largometraje animado

\section{PROTAGONISTA}

Winnie the Pooh

\section{ADAPTACIÓN}

El tono es aun más infantil que en el cuento y los personajes se han adaptado al estilo de Disney, cambiando el encanto original de las ilustraciones. La historia es algo distinta pero el tema principal se mantiene. Tema y tono similares.

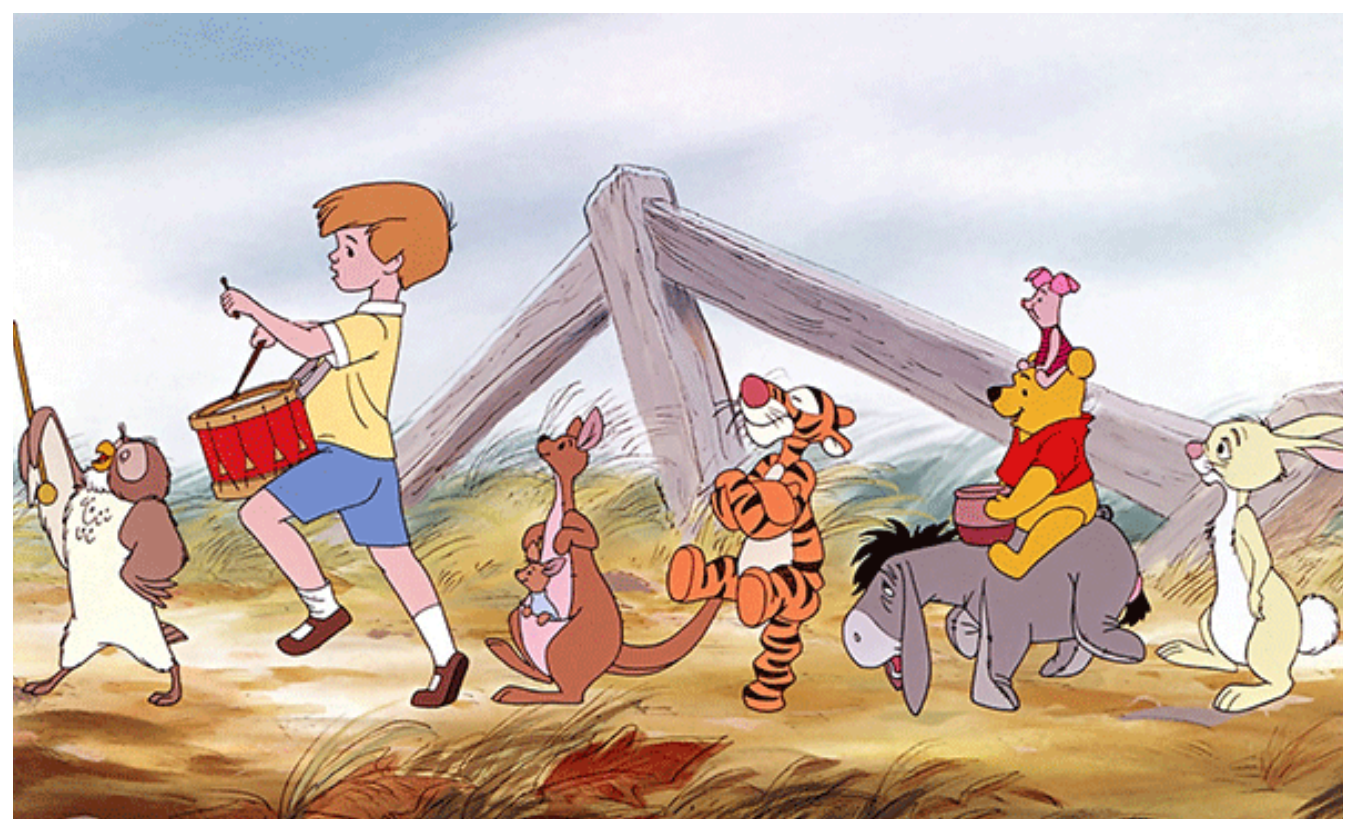


13a. Libro: Rosie's walk.

Hutchins, 1968

\section{REGISTRO}

Título: El paseo de Rosita

Autor: Pat Hutchins

Año de publicación: 1968

Editorial: Macmillan

Público objetivo: niños a partir de 5 años

\section{GÉNERO}

Cotidianeidad

\section{ILUSTRACIÓN}

Técnica: línea a tinta, colores planos (rojo, amarillo, verde)

Iconicidad: caricatura realista de animales

Transmite: es divertido, vivaz

FORMATO
Álbum ilustrado

TAMAÑO DEL LIBRO

$21 \times 26 \mathrm{~cm}$

Encuadernación: tapa dura. Cartoné $\mathrm{N}^{\circ}$ de páginas: 32

\section{RELACIÓN IMAGEN/TEXTO \\ Contrapunto}

PROTAGONISTA

La gallina Rosie

\section{CONTENIDO}

Sinopsis: La gallina Rosie pasea por el corral, sin darse cuenta que un zorro la sigue. A pesar de su distracción, ella consigue involucrar al zorro en accidente tras accidente.

Mensaje: enseña humor e ironía a los más pequeños

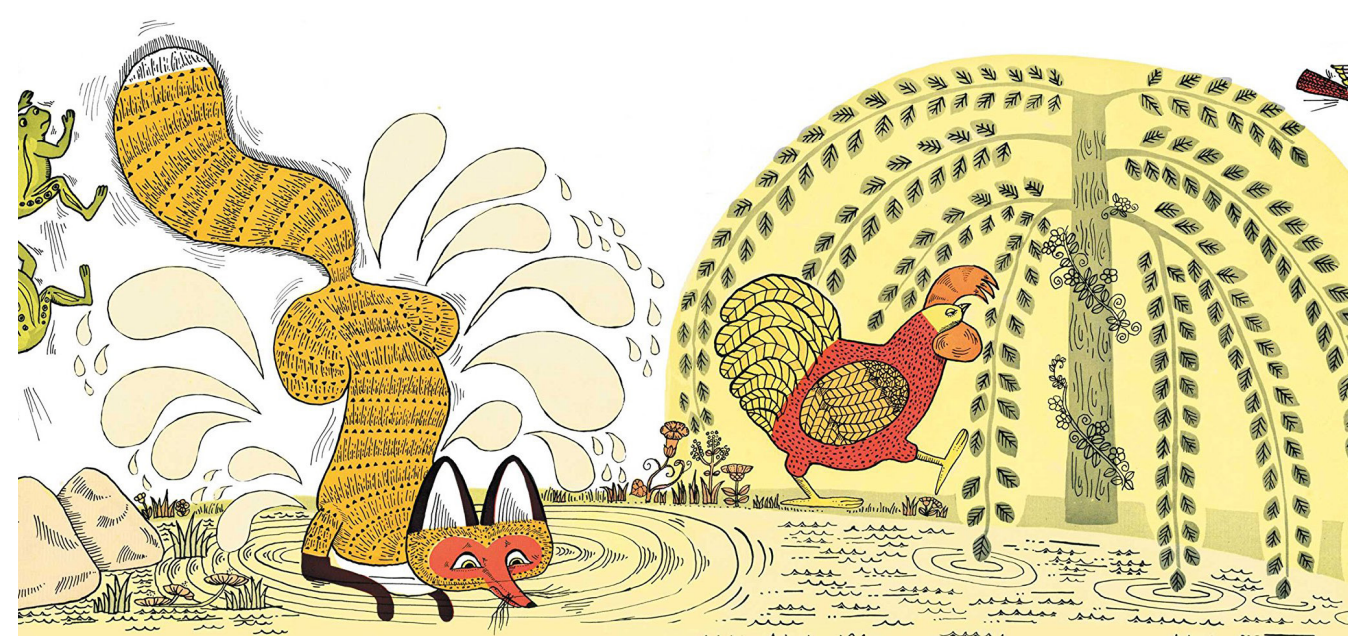


13b. Audiovisual: Rosie's walk.

Deitch, 1970

\section{REGISTRO}

Título: Rosie's walk

Director: Gene Deitch

Guion: (Álbum)

Productora: Weston Woods

Año de estreno: 1970

País: Estados Unidos y Checoslova-

quia

Público objetivo: niños a partir de 5 años

Duración: 4 minutos

Audio: Música y narración voz en off

TÉCNICA

Animación tradicional 2D

FORMATO

Cortometraje

\section{ADAPTACIÓN}

El estilo de la animación es idéntico a las ilustraciones, con escaso movimiento.

Tema y tono muy similares.

\section{GÉNERO}

Ficción

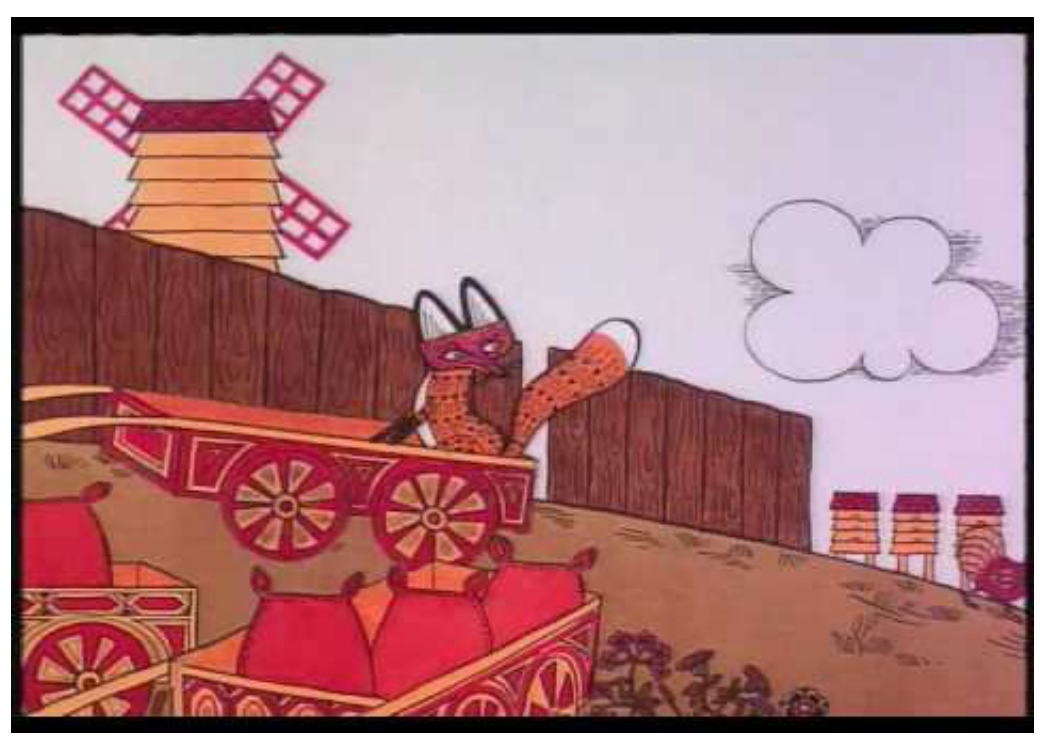


14a. Libro: The Ant Bully.

John Nickle, 1999

\section{REGISTRO}

Título: The Ant Bully

Autor: John Nickle

Año de publicación: 1999

Editorial: Scholastic

Público objetivo: niños a partir de 7 años

\section{GÉNERO}

Fantástico

\section{ILUSTRACIÓN}

Técnica: acrílico en papel de acuarela

Iconicidad: caricatura realista

Transmite: son dibujos que casi pertenecen a un libro de texto pero más exagerados

FORMATO

Álbum ilustrado
TAMAÑO DEL LIBRO

$10^{\prime} 2 \times 11^{\prime} 2 \mathrm{~cm}$

Encuadernación: tapa dura. Cartoné $\mathrm{N}^{\circ}$ de páginas: 32

\section{RELACIÓN IMAGEN/TEXTO \\ Complemento}

\section{PROTAGONISTA}

Lucas, un niño de 10 años

\section{CONTENIDO}

Sinopsis: Como no puede defenderse de un niño más fuerte y malo que él, Lucas se desfoga torturando a las hormigas, pero ellas van a enseñarle una lección sobre ser un abusón.

Mensaje: anti-bullying

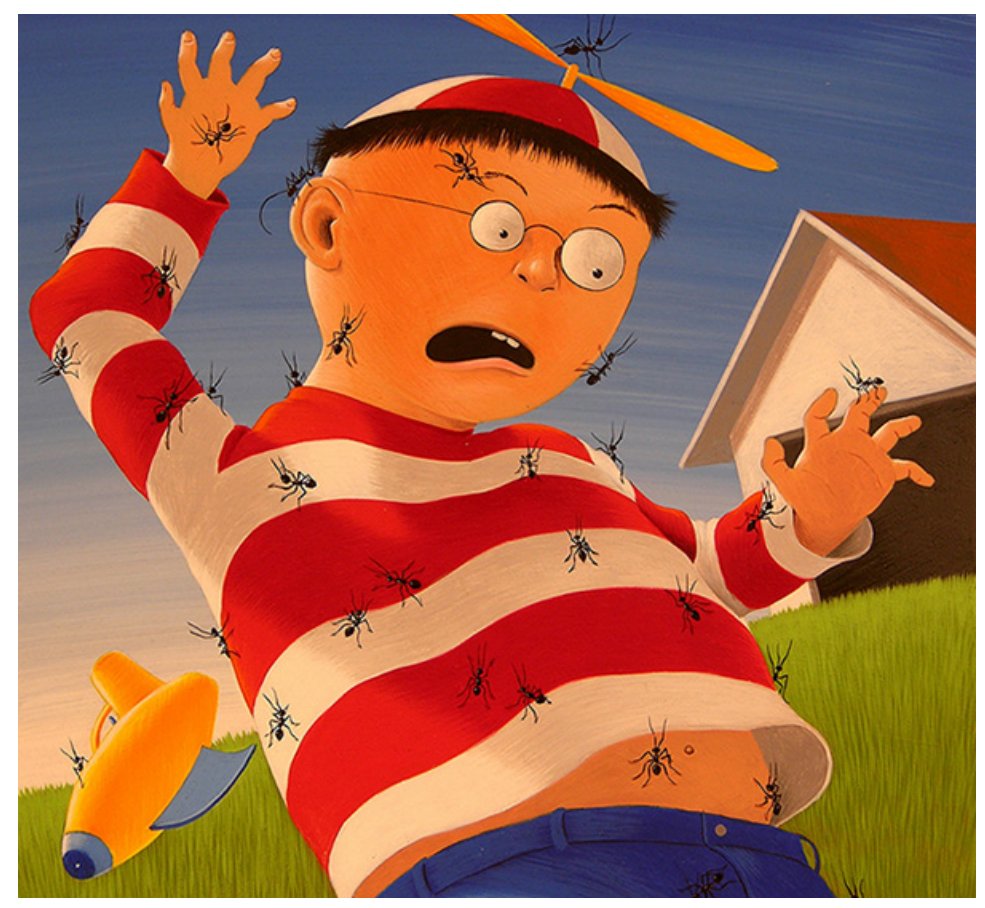


14b. Audiovisual: The Ant Bully.

John A. Davis, 2006

\section{REGISTRO}

Título: Ant Bully, bienvenido al

hormiguero

Director: John A. Davis

Guion: John Nickle

Productora: Warner Bros.

Año de estreno: 2006

País: Estados Unidos

Público objetivo: niños a partir de 6 años

Duración: 90 minutos

\section{GÉNERO}

Ficción, fantasía, comedia

\section{TÉCNICA}

Animación por ordenador 3D

\section{FORMATO}

Largometraje

\section{CONTENIDO}

Sinopsis: Al pobre Lucas Nickle, un niño de 10 años, todo le sale mal. Hace poco que se ha mudado a una nueva ciudad con su familia y no se ha hecho ni un amigo.
Mientras tanto la abuela, cariñosa pero algo excéntrica, dedica su tiempo a proteger a la familia de unos extraterrestres que conoce a través de la prensa sensacionalista. Por si esto no fuera suficiente, Lucas es el blanco favorito del "bully" del lugar quién no pierde oportunidad de intimidarle. A su vez, Lucas disfruta destruyendo los pequeños montículos que forman las hormigas en su jardín - descarga su frustración sobre los montículos de tierra y sus minúsculos habitantes pataleándoles, pisoteándoles, y regándoles con la manguera.

\section{ADAPTACIÓN}

El tema se alarga para adaptarse al tiempo de una película, desarrollando más la personalidad de Lucas, su entorno, las hormigas y su tiempo con ellas. El tono es más humorístico que en el original y se centra más en la acción.

Tema similar y tono algo distinto.

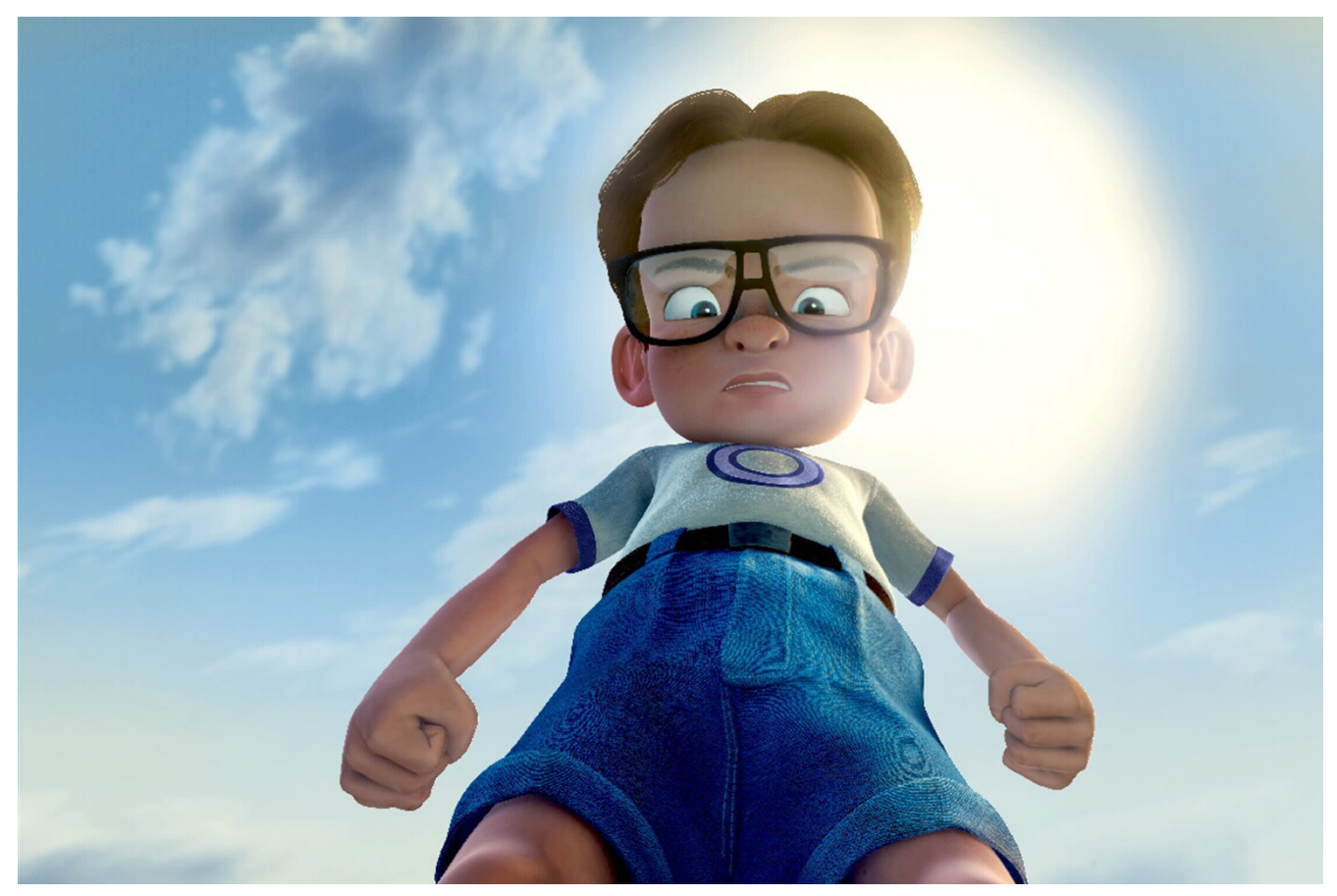


15a. Libro: Lost and Found.

Oliver Jeffers, 2005

\author{
REGISTRO \\ Título: Perdido y encontrado \\ Autor: Oliver Jeffers \\ Año de publicación: 2005 \\ Editorial: Harper Collins \\ Público objetivo: niños de 4 a 7 años \\ GÉNERO \\ Fantástico

\section{ILUSTRACIÓN} \\ Técnica: acuarela \\ Iconicidad: caricatura \\ Transmite: sensación de sueño, so- \\ ledad

\section{FORMATO \\ Álbum ilustrado} \\ TAMAÑO DEL LIBRO \\ $19 \times 19 \mathrm{~cm}$ \\ Encuadernación: tapa blanda \\ $\mathrm{N}^{\circ}$ de páginas: 32
}

\section{RELACIÓN IMAGEN/TEXTO \\ Complemento}

\section{PROTAGONISTA}

Un niño

\section{CONTENIDO}

Sinopsis: Un niño encuentra un pingüino extraviado en la entrada de su casa. Al verlo solo y triste decide ayudarlo a encontrar el camino de regreso a su hogar. Tras mucho investigar, averigua que los pingüinos habitan en el Polo Norte y busca la forma de llevarlo allí. Durante el viaje descubre que la soledad no es lo mismo que la nostalgia del hogar.

Mensaje: amistad

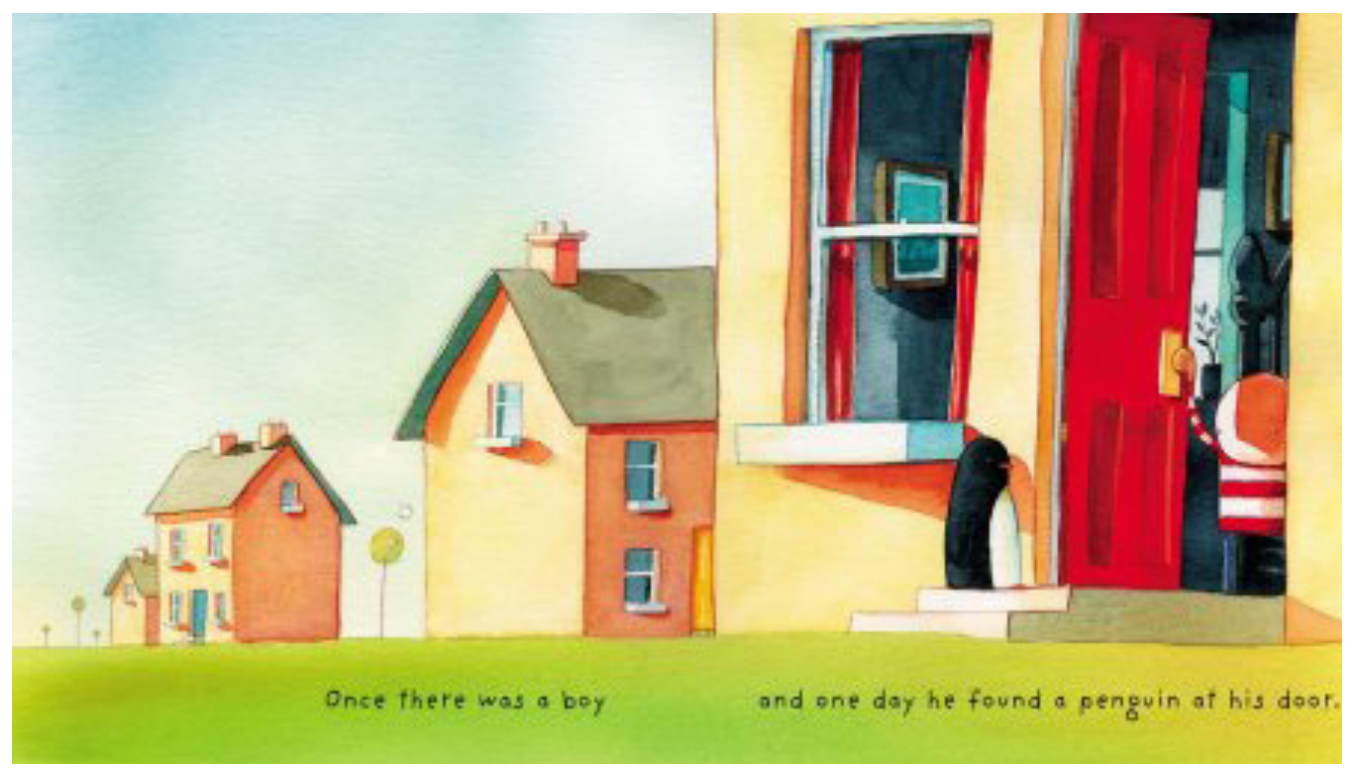


15b. Audiovisual: Lost and Found.

Philip Hunt, 2008

\begin{tabular}{|c|c|}
\hline REGISTRO & \\
\hline Título: Perdido y encontrado & FORMATO \\
\hline Director: Philip Hunt & Mediometraje \\
\hline Guion: Oliver Jeffers & \\
\hline Productora: Contender Entertain- & ADAPTACIÓN \\
\hline $\begin{array}{l}\text { ment Group / Studıo Aka } \\
\text { Año de estreno: } 2008\end{array}$ & $\begin{array}{l}\text { El estilo de la anımacion es sımılar } \\
\text { a las ilustraciones, pero en } 3 \mathrm{D} \text {, tra- }\end{array}$ \\
\hline País: Reino Unido & duciendo los fondos de acuareala en \\
\hline $\begin{array}{l}\text { Público objetivo: niños a partir de } 4 \\
\text { años }\end{array}$ & $\begin{array}{l}\text { grandes extensiones de color que } \\
\text { también capturan esa sensación de }\end{array}$ \\
\hline Duración: 24 minutos & soledad que refleja el álbum. La his- \\
\hline Audio: Música y narración voz en off & $\begin{array}{l}\text { toria la sigue casi paso a paso, alar- } \\
\text { gando algo más las acciones y na- }\end{array}$ \\
\hline GÉNERO & rrando en voz en off algo menos que \\
\hline Ficción & $\begin{array}{l}\text { el original pero con el mismo tono. } \\
\text { Tema y tono muy similares. }\end{array}$ \\
\hline
\end{tabular}

TÉCNICA

Animación por ordenador 3D

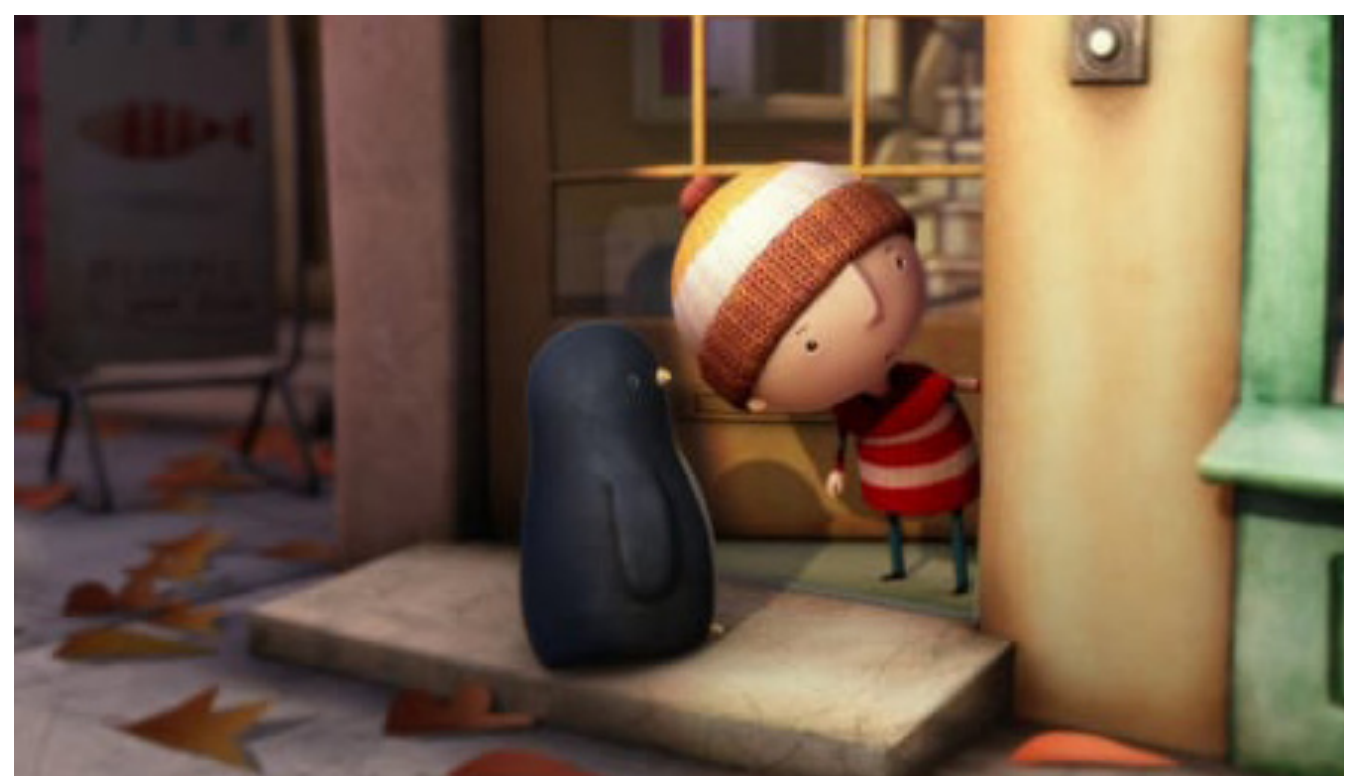


16a. Libro: Ferdinand.

Robert Lawson, Munro Leaf, 1936

\section{REGISTRO}

Título: El cuento de Ferdinando

Autor: Robert Lawson, Munro Leaf

Año de publicación: 1936

Editorial: Viking Press

Público objetivo: niños a partir de 5 años

\section{GÉNERO}

Fantástico

\section{ILUSTRACIÓN}

Técnica: tinta con tramas y texturas Iconicidad: caricatura realista Transmite: con un estilo clásico consigue comunicar humor

\section{FORMATO \\ Libro ilustrado \\ TAMAÑO DEL LIBRO \\ $23 \times 23 \mathrm{~cm}$ \\ Encuadernación: tapa dura \\ $\mathrm{N}^{\circ}$ de páginas: 72}

\section{RELACIÓN IMAGEN/TEXTO \\ Complemento}

\section{PROTAGONISTA \\ El toro Ferdinand}

\section{CONTENIDO}

Sinopsis: Al joven toro Ferdinando no le gusta pelear, prefiriendo olisquear las flores bajo un árbol. Cuando los terneros crecen, Ferdinando resulta ser el más grande y más fuerte de los novillos. Todos los otros toros tienen el sueño de ser elegidos para competir en las corridas de toros en Madrid, pero Ferdinando todavía prefiere oler las flores. Cuando Ferdinando es llevado a la plaza de Madrid, en lugar de resultar feroz, se acuesta en medio del ruedo para disfrutar de las flores que llevan las señoras. Ferdinando es enviado de nuevo a su prado, donde sigue oliendo las flores.

Mensaje: pacifismo

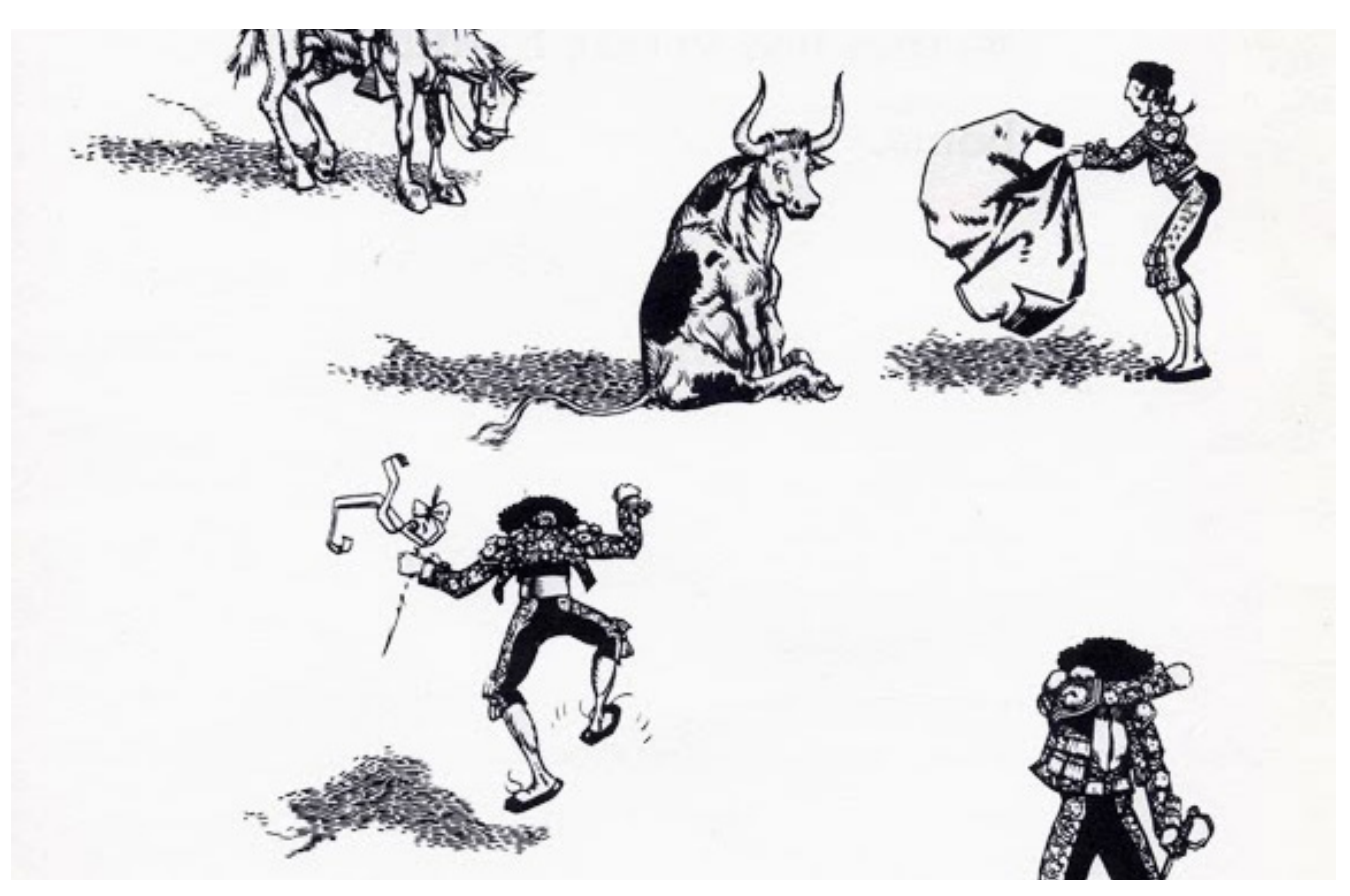


16b. Audiovisual: Ferdinand.

Carlos Saldanha, 2017

\author{
REGISTRO \\ Título: Ferdinand \\ Director: Carlos Saldanha \\ Guion: Robert L. Baird, Tim Federle, \\ Brad Copeland (Historia: Ron Burch, \\ David Kidd, Don Rhymer. Cuento: \\ Munro Leaf) \\ Productora: Blue Sky Studios / 20th \\ Century Fox Animation / Davis Enter- \\ tainment. Distribuida por 20th Cen- \\ tury-Fox Film Corporation \\ Año de estreno: 2017 \\ País: Estados Unidos \\ Público objetivo: niños a partir de 6 \\ años \\ Duración: 106 minutos \\ GÉNERO \\ Ficción, comedia
}

\author{
TÉCNICA \\ Animación por ordenador 3D

\section{FORMATO \\ Largometraje} \\ ADAPTACIÓN
}

Se mantiene la historia del toro original, pero se añaden nuevos personajes y matices a la trama, entre ellos distintos animales y una niña. El tono cambia y se hace más genérico, centrado en las aventuras de Ferdinand, perdiendo el matiz humorístico y despreocupado del original. Tema similar y tono diferente.

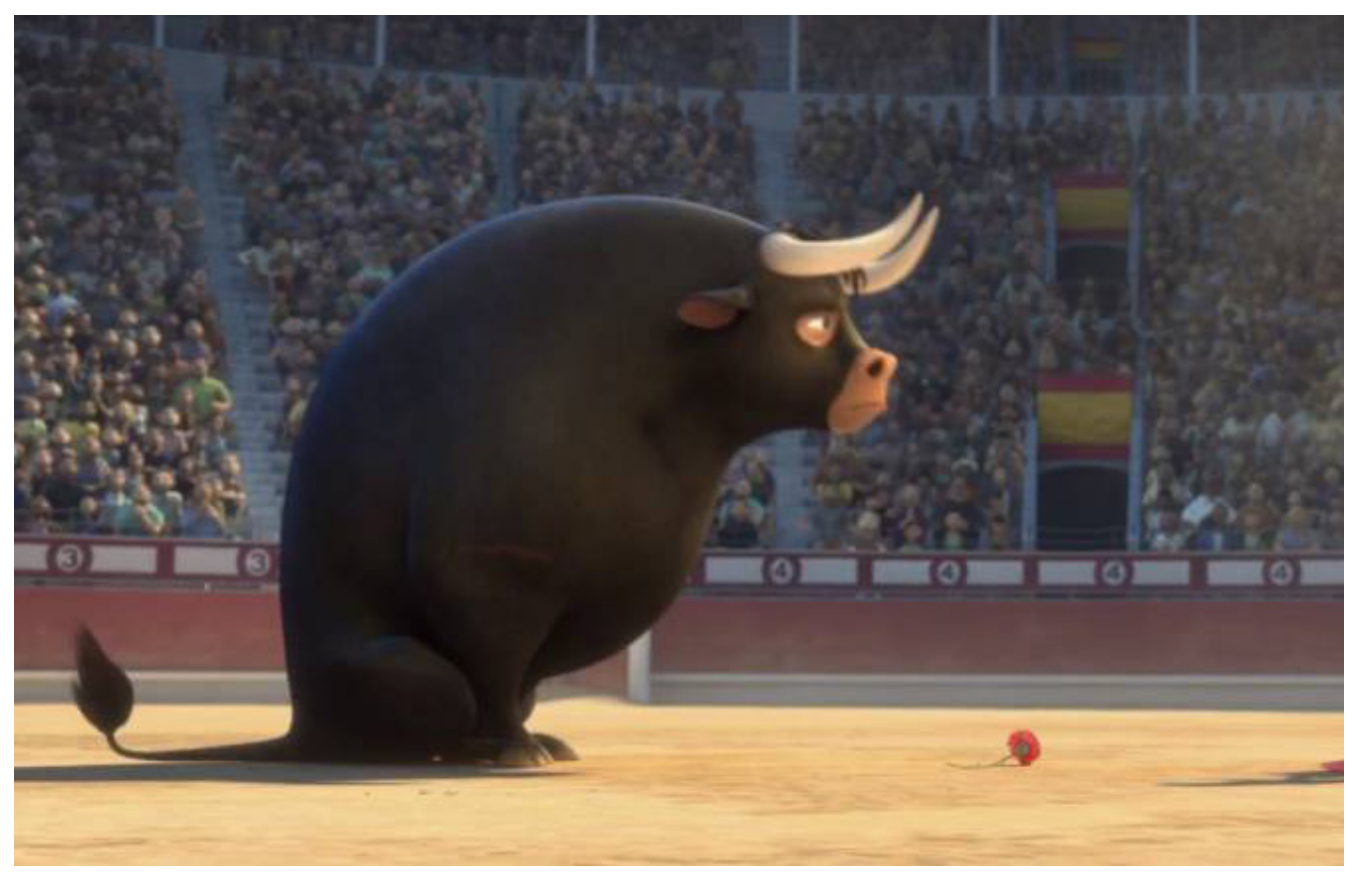


17a. Libro: The boss baby.

Marla Frazee, 2010

\section{REGISTRO}

Título: El bebé jefazo

Autor: Marla Frazee

Año de publicación: 2010

Editorial: Beach Lane Books, Simon

\& Schuster

Público objetivo: niños a partir de 3 años

\section{GÉNERO}

Fantástico

\section{ILUSTRACIÓN}

Técnica: lápiz, acuarelas, lápiz de color, grafito

Iconicidad: caricatura

Transmite: Humor

\section{FORMATO}

Álbum ilustrado
TAMAÑO DEL LIBRO

$25^{\prime} 4 \times 22{ }^{\prime} 5 \mathrm{~cm}$

Encuadernación: tapa dura

$\mathrm{N}^{\circ}$ de páginas: 32

\section{RELACIÓN IMAGEN/TEXTO \\ Complemento}

\section{PROTAGONISTA}

El nuevo bebé y sus padres

\section{CONTENIDO}

Sinopsis: En cuanto el bebé jefazo llegó a casa, dejó muy claro quién mandaba allí: puso a papá y mamá a trabajar las 24 horas del día, jsin descansos ni nada!

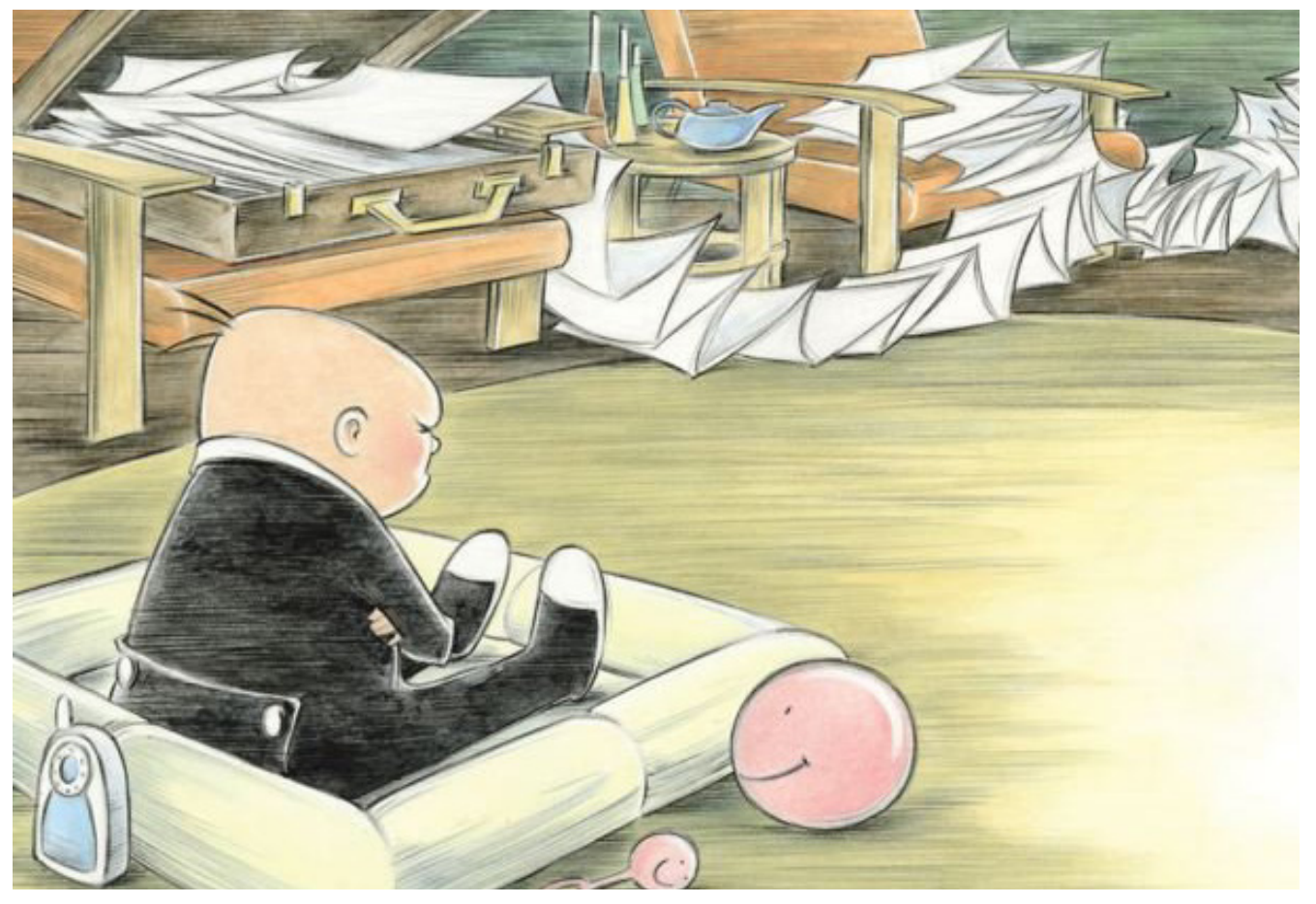


17b. Audiovisual: The boss baby.

\section{Tom McGrath, 2017}

\section{REGISTRO}

Título: El bebé jefazo

Director: Tom McGrath

Guion: Michael Mccullers

Productora: DreamWorks Animation

/ 20th Century-Fox Film Corporation

Año de estreno: 2017

País: Estados Unidos

Público objetivo: niños a partir de 6 años

Duración: 97 minutos

\section{GÉNERO}

Ficción, comedia

\section{TÉCNICA}

Animación por ordenador 3D

\section{FORMATO}

Largometraje

\section{PROTAGONISTA}

Tim, el hermano del nuevo bebé (personaje que no aparece en el original)

\section{CONTENIDO}

Sinopsis: La llegada de un hermanito trastoca por completo la idílica vida del pequeño Tim, hasta entonces hijo único de 7 años y el ojito derecho de sus padres. Su nuevo hermano es un peculiar bebé, que viste traje y corbata y lleva maletín. Tim comienza a sospechar de él, hasta que descubre que puede hablar.

\section{ADAPTACIÓN}

Tema y tono diferentes. El narrador que en el álbum es un ser omnisciente, en la película se trata del hermano mayor, que se convierte en el protagonista con el que empatizamos. Piierde el tono sencillo, irónico y divertido del original, centrándose más en la acción, que difiere totalmente del álbum.

Tema y tono diferentes.

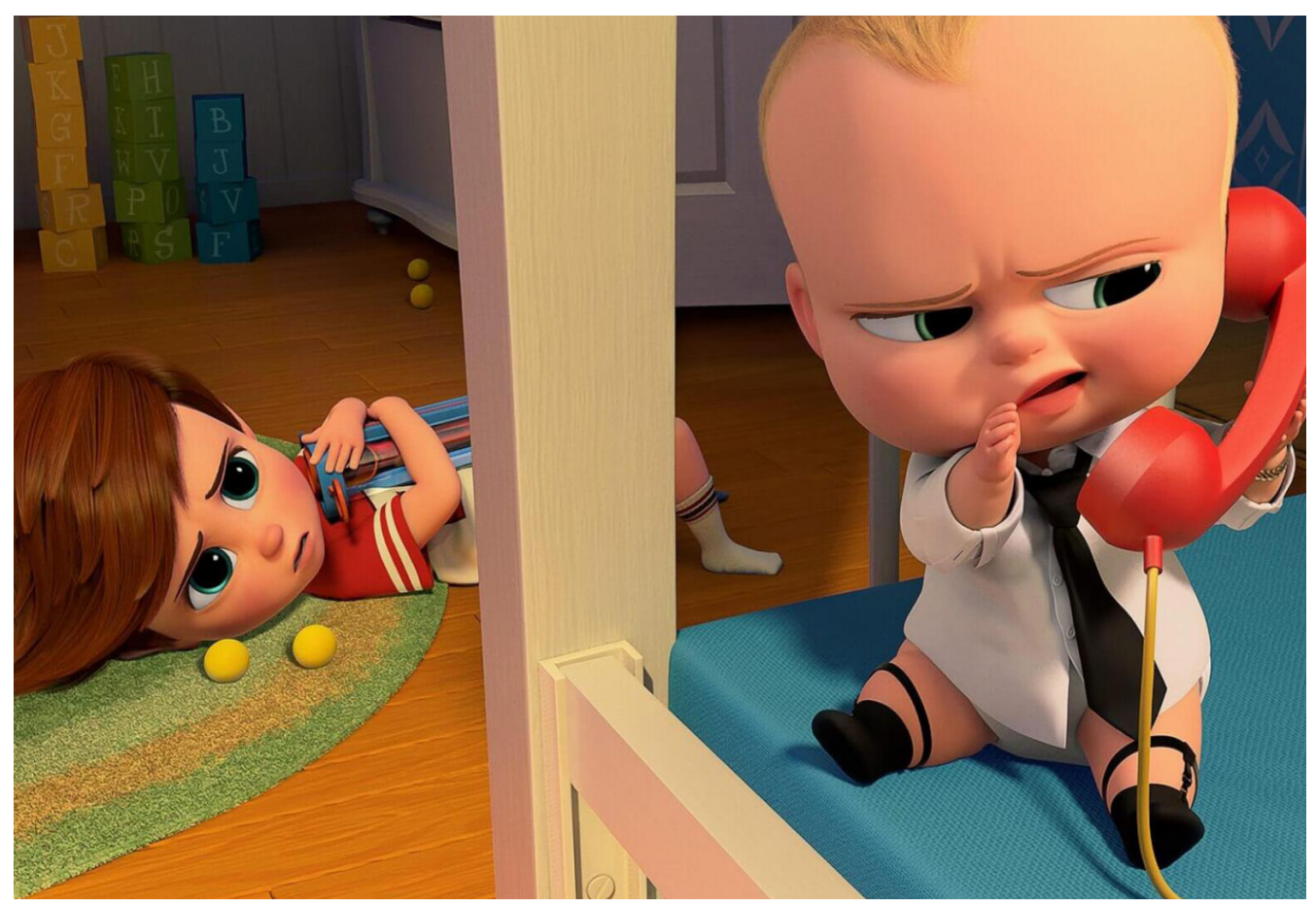


18a. Libro: Les poings sur les îles.

Elise Fontenaille, Violeta Lópiz, 2011

\section{REGISTRO}

Título: Los puños sobre las islas, A cartón pintado (Argentina)

Autor: Elise Fontenaille, Violeta Lópiz

Año de publicación: 2011

Editorial: Éditions du Rouergue Público objetivo: niños a partir de 6 años

\section{GÉNERO \\ Realismo \\ ILUSTRACIÓN}

Técnica: acrílico y ceras sobre papel y acetato

Iconicidad: caricatura

Transmite:

\section{FORMATO \\ Álbum ilustrado}

\section{TAMAÑO DEL LIBRO}

$21 \times 29 \mathrm{~cm}$

Encuadernación: tapa dura $\mathrm{N}^{\circ}$ de páginas: 26

\section{RELACIÓN IMAGEN/TEXTO \\ Complemento}

\section{PROTAGONISTA}

El narrador, un niño pequeño

\section{CONTENIDO}

Sinopsis: Al narrador de esta historia le encanta pasar las vacaciones con su abuelo Luis en una casita que está en medio de un exuberante jardín. Allí repasa la lección, pero sobre todo, aprende cosas increíbles, como el nombre de las plantas silvestres o el de los pájaros del bosque. Su abuelo sabe mucho de esas cosas. Luis llegó a Francia caminando desde España cuando era niño y huía de la guerra. Es por eso que Luis no sabe leer ni escribir, ni siquiera su nombre. Sin embargo, tiene muy buena mano con las plantas, dibuja genial, habla el idioma de los pájaros, es un cocinero excepcional, toca la guitarra y canta canciones en español.

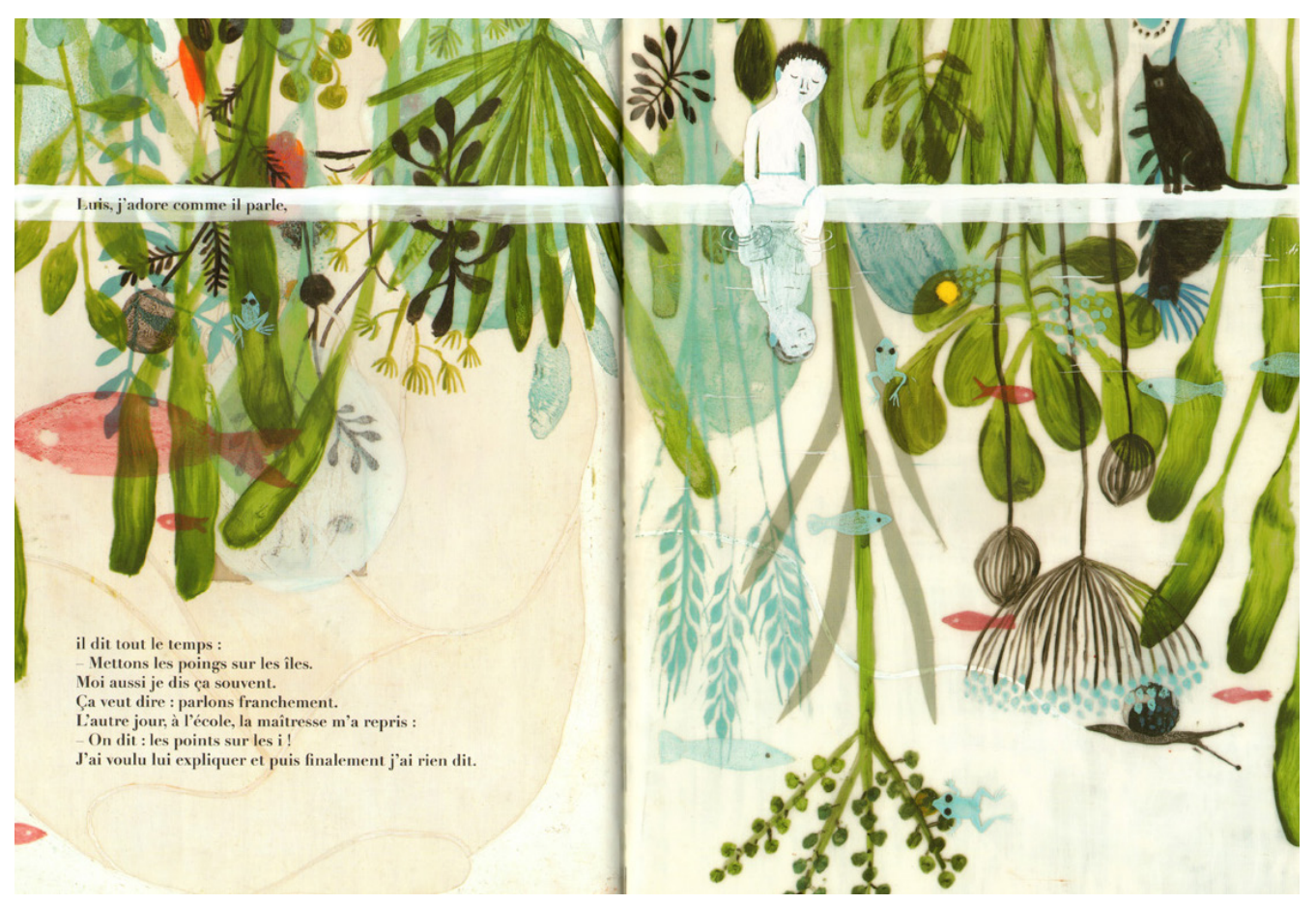


18b. Audiovisual: Les poings sur les îles. Lu Bing, 2013

\author{
REGISTRO \\ Título: Les poings sur les îles \\ Director: Lu Bing \\ Guion: Kwon Seulki \\ Productora: CJ animation \\ Año de estreno: 2013 \\ País: Korea \\ Público objetivo: niños a partir de 6 \\ años \\ Duración: 5 minutos

\section{GÉNERO \\ Realismo} \\ TÉCNICA \\ Animación 2D. Dibujo tradicional ani- \\ mado con ordenador
}

\section{FORMATO \\ Cortometraje}

\section{ADAPTACIÓN}

La narración en off por el niño protagonista (como en el álbum) sigue el original casi palabra por palabra. El estilo de la animación imita la técnica de las ilustraciones, haciendo que parezca que el álbum mismo ha cobrado movimiento.

Tema y tono iguales.

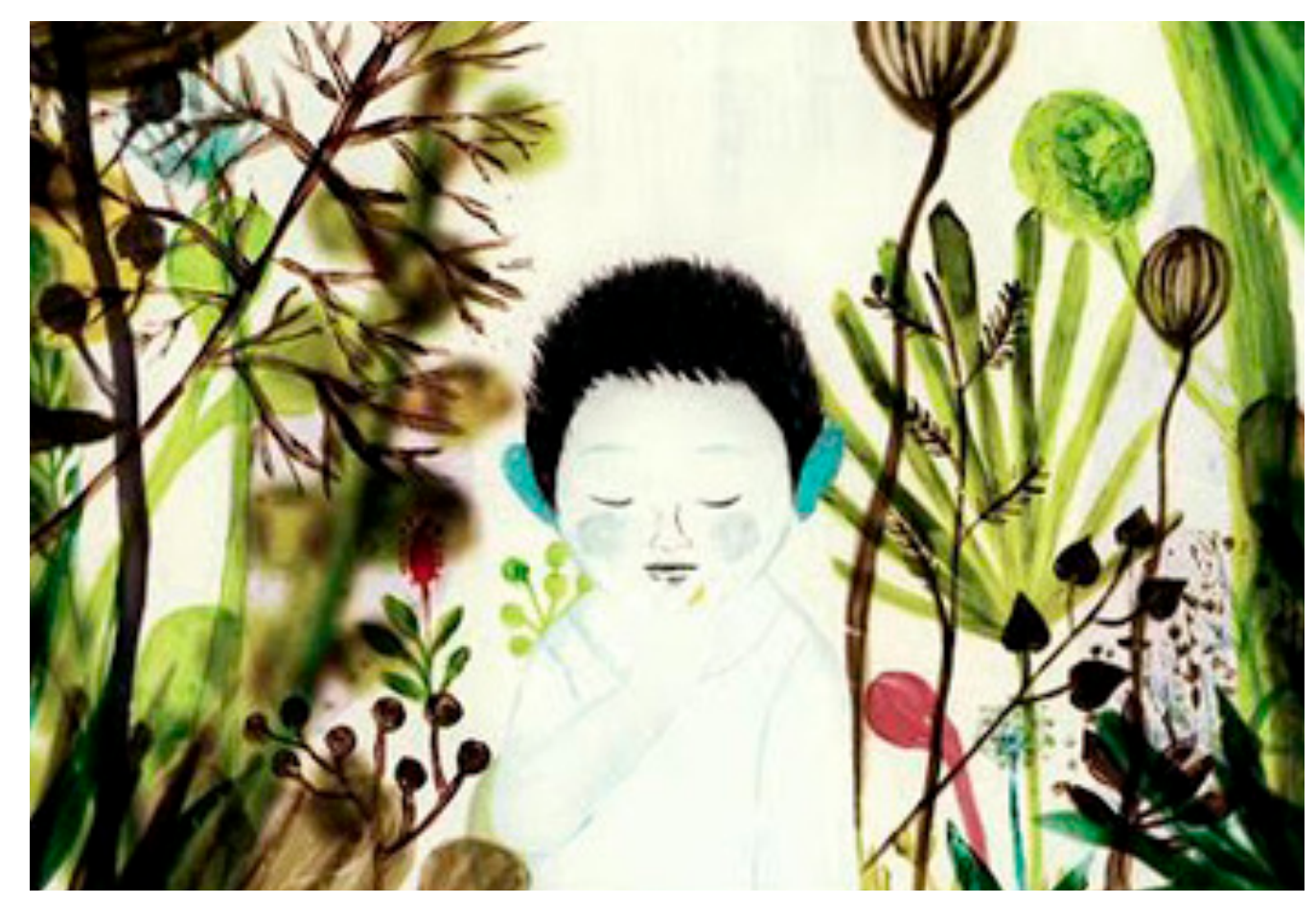


5.3.2. Comparativa entre el original y la adaptación

\begin{tabular}{|c|c|c|c|c|}
\hline OBRA & TEMA & TONO & PROTAGONISTA & FORMATO \\
\hline $\begin{array}{l}\text { El cazo de } \\
\text { Lorenzo. Isa- } \\
\text { belle Carrier, } \\
2010 \text { => Éric } \\
\text { Montchaud, } \\
2014\end{array}$ & Semejante & Semejante & El mismo & Cortometraje \\
\hline $\begin{array}{l}\text { The lost } \\
\text { thing. Shaun } \\
\text { Tan, } 2000 \\
=>\text { Andrew } \\
\text { Ruhemann \& } \\
\text { Shaun Tan, } \\
2010\end{array}$ & Semejante & Semejante & $\begin{array}{l}\text { El mismo } \\
\text { (narrador) }\end{array}$ & Cortometraje \\
\hline $\begin{array}{l}\text { Where the } \\
\text { Wild Things } \\
\text { Are. Maurice } \\
\text { Sendak, } 1963 \\
=>\text { Spike Jon- } \\
\text { ze, } 2009\end{array}$ & Distinto & Distinto & $\begin{array}{l}\text { El mismo } \\
\text { (más importancia } \\
\text { los monstruos) }\end{array}$ & Largometraje \\
\hline $\begin{array}{l}\text { A day with } \\
\text { Wilbur Robin- } \\
\text { son. William } \\
\text { Joyce, } 1990 \\
\text { => Meet the } \\
\text { Robinsons. } \\
\text { Stephen J. } \\
\text { Anderson, } \\
2007\end{array}$ & Distinto & Semejante & $\begin{array}{l}\text { Distinto } \\
\text { (Lewis es prac- } \\
\text { ticamente otro } \\
\text { personaje) }\end{array}$ & Largometraje \\
\hline $\begin{array}{l}\text { The Polar Ex- } \\
\text { press. Chris } \\
\text { Van Allsburg, } \\
1985=>\text { Ro- } \\
\text { bert Zemec- } \\
\text { kis, } 2004\end{array}$ & Semejante & Distinto & El mismo & Largometraje \\
\hline
\end{tabular}




\begin{tabular}{|c|c|c|c|c|}
\hline $\begin{array}{l}\text { Shrek! Wi- } \\
\text { Iliam Steig, } \\
1990=> \\
\text { Shrek. An- } \\
\text { drew Adam- } \\
\text { son y Vicky } \\
\text { Jenson, } 2001\end{array}$ & Distinto & Semejante & $\begin{array}{l}\text { El mismo } \\
\text { (más desarrollo } \\
\text { otros personajes) }\end{array}$ & Largometraje \\
\hline $\begin{array}{l}\text { The Gruffalo. } \\
\text { Julia Donald- } \\
\text { son, Axel } \\
\text { Scheffler, } \\
1999=>\text { Max } \\
\text { Lang, Jakob } \\
\text { Schuh, } 2009\end{array}$ & Semejante & Semejante & El mismo & Mediometraje \\
\hline $\begin{array}{l}\text { Cloudy with } \\
\text { a chance of } \\
\text { meatballs. } \\
\text { Judi \& Ron } \\
\text { Barret, } 1978 \\
=>\text { Chris Mi- } \\
\text { ller, Phil Lord } \\
2009\end{array}$ & Distinto & Distinto & $\begin{array}{l}\text { Distinto } \\
\text { (protagonista no } \\
\text { aparece en el } \\
\text { original) }\end{array}$ & Largometraje \\
\hline $\begin{array}{l}\text { The Guar- } \\
\text { dians of } \\
\text { Childhood. } \\
\text { William } \\
\text { Joyce, } 2010 \\
\text { => Rise of } \\
\text { the Guar- } \\
\text { dians. Peter } \\
\text { Ramsey, } \\
2012\end{array}$ & Distinto & Semejante & $\begin{array}{l}\text { Distinto } \\
\text { (todo el protago- } \\
\text { nismo lo tiene un } \\
\text { personaje distin- } \\
\text { to de la saga) }\end{array}$ & Largometraje \\
\hline
\end{tabular}




\begin{tabular}{|c|c|c|c|c|}
\hline $\begin{array}{l}\text { Horton hears } \\
\text { a who, Dr. } \\
\text { Seuss, } 1954 \\
=>\text { Jimmy Ha- } \\
\text { yward, Steve } \\
\text { Martino, } 2008\end{array}$ & Semejante & Distinto & El mismo & Largometraje \\
\hline $\begin{array}{l}\text { The fantastic } \\
\text { flying books } \\
\text { of Mr Morris } \\
\text { Lessmore. } \\
\text { William Joy- } \\
\text { ce, } 2011=> \\
\text { William Joy- } \\
\text { ce, Brandon } \\
\text { Oldenburg, } \\
2011\end{array}$ & Semejante & Semejante & El mismo & Cortometraje \\
\hline $\begin{array}{l}\text { Winnie the } \\
\text { Pooh. A. A. } \\
\text { Milne, E. H. } \\
\text { Shepard, } \\
1926 \text { => John } \\
\text { Lounsbery, } \\
\text { Wolfgang } \\
\text { Reitherman, } \\
1977\end{array}$ & Semejante & Semejante & $\begin{array}{l}\text { Distinto } \\
\text { (Pooh mucho } \\
\text { más protagonis- } \\
\text { mo) }\end{array}$ & Largometraje \\
\hline $\begin{array}{l}\text { Rosie's walk. } \\
\text { Hutchins } \\
1968=> \\
\text { Deitch, } 1970\end{array}$ & Semejante & Semejante & Semejante & Cortometraje \\
\hline $\begin{array}{l}\text { The Ant Bully. } \\
\text { John Nickle, } \\
1999=>\text { Ant } \\
\text { Bully: Las } \\
\text { aventuras de } \\
\text { Lucas. John } \\
\text { A. Davis, } \\
2006\end{array}$ & Distinto & Distinto & $\begin{array}{l}\text { El mismo } \\
\text { (más desarrollo } \\
\text { otros personajes) }\end{array}$ & Largometraje \\
\hline
\end{tabular}




\begin{tabular}{|c|c|c|c|c|}
\hline $\begin{array}{l}\text { Lost and } \\
\text { Found. Oliver } \\
\text { Jeffers, } 2005 \\
\text { => Philip } \\
\text { Hunt, Joanna } \\
\text { Lurie, Jea- } \\
\text { nine Reute- } \\
\text { mann, } 2008\end{array}$ & Semejante & Semejante & El mismo & Mediometraje \\
\hline $\begin{array}{l}\text { Ferdinand. } \\
\text { Robert Law- } \\
\text { son, Munro } \\
\text { Leaf, } 1936 \text { => } \\
\text { Carlos Sal- } \\
\text { danha, } 2017\end{array}$ & Semejante & Distinto & $\begin{array}{l}\text { El mismo } \\
\text { (y nuevos perso- } \\
\text { najes) }\end{array}$ & Largometraje \\
\hline $\begin{array}{l}\text { The boss } \\
\text { baby. Marla } \\
\text { Frazee, } 2010 \\
\text { => Tom Mc- } \\
\text { Grath, } 2017\end{array}$ & Distinto & Distinto & $\begin{array}{l}\text { Distinto } \\
\text { (personaje que } \\
\text { no aparece en el } \\
\text { original) }\end{array}$ & Largometraje \\
\hline $\begin{array}{l}\text { Les poings } \\
\text { sur les îles. } \\
\text { Elise Fonte- } \\
\text { naille, Violeta } \\
\text { Lópiz, } 2011 \\
\text { => Lu Bing, } \\
2013\end{array}$ & Semejante & Semejante & $\begin{array}{l}\text { El mismo } \\
\text { (narrador) }\end{array}$ & Cortometraje \\
\hline
\end{tabular}

Así pues, de entre las adaptaciones escogidas encontramos:

- Cortometrajes: 5

- Largometrajes: 11

- Mediometrajes: 2 
De los cuales:

- Mantienen el tema: 11. De los cuales 5 son cortometrajes, 2 mediometrajes, 4 largometrajes

- Mantienen el tono: 11. De los cuales 5 son cortometrajes, 2 mediometrajes, 4 largometrajes

- Mismo protagonista: 13. De los cuales 5 son cortometrajes, 2 mediometrajes, 4 largometrajes

Los 5 cortometrajes y 2 mediometrajes mantienen el mismo (o similar) tono, tema y protagonista que el álbum o libro ilustrado.

Los largometrajes alternan entre cambiar el tono, el tema o el protagonista. Dos de ellos alteran absolutamente todo: "Cloudy with a chance of meatballs" (Chris Miller, Phil Lord 2009) y "The boss baby" (Tom McGrath, 2017).

De esta manera podemos hablar de una clasificación sencilla de las adaptaciones de acuerdo a lo que difieren del original:

- Tema y tono semejante

- Tema semejante y tono diferente

- Tema diferente y tono semejante

- Tema y tono diferente

Y a parte de esto hablaremos de un cambio en el protagonista o los personajes principales o la mantenencia del mismo.

\subsubsection{Tema y tono semejante}

Según lo visto en esta selección, todos los audiovisuales con menos franja de tiempo se mantienen relativamente fieles al original, tal es el caso de "El cazo de Lorenzo" (Montchaud, 2014), "The lost thing" (Ruhemann \& Tan, 2010), "The Gruffalo" (Lang, Schuh, 2009), "The fantastic flying books of Mr Morris Lessmore" (Joyce, Oldenburg, 2011), "Rosie's walk" (Deitch, 1970), "Lost and Found" (Hunt, Lurie, Reutemann, 2008) y "Les poings sur les îles" (Lu Bing, 2013). En dos de estos casos (Tan y Joyce) el autor del álbum se encuentra involucrado con la creación del audiovisual.

En todos estos casos además, el estilo de la animación y el diseño de personajes son muy similares a las ilustraciones del álbum, consiguiendo que la relación entre ambos sea más evidente y la traducción de un medio a otro mucho más fluida. En algunas de estas adaptaciones puede parecer que el propio original ha cobrado vida, como es el caso de "Les poings sur les îles".

Así mismo es notable el hecho de que todos ellos, excepto "The fantastic flying books of Mr Morris Lessmore", que es totalmente muda, y "The Gruffalo", cuentan con un narrador. En algunos casos es el propio protagonista el que actúa como narrador ("The lost thing", "Les poings sur les îles"). Tampoco existe ningún tipo de diálogo en ninguna, a excepción del mediometraje "The Gruffalo". 
Podemos pues plantear que cuanto más larga es la adaptación más cambios sufre la historia, el tono, el tema e incluso los protagonistas. Especialmente si tenemos en cuenta que la longitud de los álbumes suele rondar las 32 páginas, por lo que un largometraje debe prolongar la historia en el tiempo de formas que no se pueden llevar a cabo sin alterar minimamente el original.

Los personajes deben desarrollarse más y la trama prolongarse sin dejar de ser entretenida y atractiva, a menudo con escenas de acción o humor para mantener al público infantil enganchado a la pantalla.

Además hemos de tener en cuenta que mientras que los cortometrajes suelen estar producidos por pequeños estudios, los largometrajes deben asegurarse un éxito económico debido al gran gasto en producción, especialmente si hablamos de animación. En múltiples ocasiones son adaptados por grandes compañías, como podemos ver en la selección que propone este trabajo, por lo que deben de cumplir una serie de expectativas y encajar con las propuestas de la "marca" de la compañía, por lo que pueden acabar distanciándose más del original.

En el caso de los largometrajes, ninguno es clasificable dentro de tema y tono semejante, a excepción tal vez de "Winnie the Pooh" (Lounsbery, Reitherman, 1977), en el que se mantiene el tono tierno e inocente del libro, aunque perdiendo la ironía que podía dejarse ver en el texto, y el tema es semejante, centrándose en la amistad y el compañerismo entre los animales y el niño. Pero incluso en este caso el estilo visual cambia significativamente con respecto al original, adaptando las ilustraciones al dibujo "marca Disney", y el protagonista de la historia deja de ser Christopher Robin, cediendo el foco a I osito Pooh, que ha llegado a convertirse en un auténtico símbolo de la compañía.

\subsubsection{Tema y tono diferente}

Dentro de tema y tono diferente podemos introducir "Where the Wild Things Are" (Jonze, 2009) y "The Ant Bully" (Davis, 2006). En ambos casos se trata de reinvenciones de la historia, en las que se mantiene la idea del original, pero cambiando o dilatando tanto a la trama que no podemos decir que sea la misma.

El argumento de "Where the Wild Things Are" solo es similar en cuanto al planteamiento original: un niño (Max) es castigado y huye de casa a través de su imaginación, pero la película ahonda en las razones de su comportamiento y establece unas relaciones entre las personas reales de la vida de Max y los monstruos. El diseño de las marionetas de los monstruos es fiel a los personajes del álbum.

"The Ant Bully" mantiene como tema secundario anti-bullying que es el predominante en el álbum, pero se centra más en las aventuras y la acción. De la misma forma el tono deja de ser el directo y algo irónico del álbum y pasa a ser uno más humorístico. El personaje de Lucas (el protagonista) se desa- 
rrolla mucho más haciéndolo más fácil de empatizar, así como toda su familia y las mismas hormigas, que en la película son humanizadas. El estilo de las ilustraciones originales no tiene nada que ver con el rediseño de los personajes en 3D para este largometraje.

Esto mismo sucede en "Cloudy with a chance of meatballs" (Miller, Lord 2009) y en "The boss baby" (McGrath, 2017), en los que además del tema y tono, el protagonista también cambia. En los dos largometrajes el protagonista es un personaje que ni siquiera aparece en el original, dándole un tono totalmente distinto y cambiando radicalmente la trama.

"Cloudy with a chance of meatballs" solo toma el libro como base, utilizando la idea de la lluvia de comida como fenómeno meteorológico pero dándole un motivo y una problemática inexistentes en el original. Crea a un inventor como protagonista y le situa como responsable de la situación, por lo que es él el que debe solucionarla, junto con un grupo de personajes que tampoco se muestran en el libro, eliminando al doble narrador original (una niña y su abuelo que le cuenta esta historia). El estilo de la animación difiere absolutamente del libro, optando por un diseño 3D "cartoon" muy exagerado, alejado del realismo que normalmente se persigue en la animación por ordenador.

En "The boss baby" vemos algo similar. El tono cargado de ironía y humor del álbum para a ser uno centrado en la acción y el chiste fácil. El tema se aleja de los padres y la perspectiva del bebé como jefe absoluto que el original maneja, inventando el personaje del hermano,Tim, y colocándolo como protagonista, haciendo que el largometraje se centre en su relación y sus aventuras, creando un villano y toda una trama que el álbum no plantea. La animación 3D no intenta asemejarse a las ilustraciones originales, presentando un diseño estándar de personajes.

\subsubsection{Tema semejante y tono diferente}

Con tema semejante y tono diferente encontramos "The Polar Express" (Zemeckis, 2004), "Horton" (Hayward, Martino, 2008) y "Ferdinand" (Saldanha, 2017). En estos casos el cambio es menos radical ya que el tema se mantiene solo con pequeñas alteraciones, dilatando la historia y añadiendo tramas para que encaje con el formato de tiempo del largometraje. Sin embargo, el tono es muy distinto al libro.

En el primer caso, "The Polar Express", desaparece el tono de misterio casi poético y sutil que vemos en el original, centrándose más en la acción. El estilo hiperrealista del CGI imita las ilustraciones, pero se adentra ligeramente en el "uncanny valley" generando cierto rechazo en el espectador y perdiendo ese clima de misterio y magia que aportan los pasteles al óleo de Van Allsburg (1985), trabajados en tonos azules y ocres.

En "Horton" desaparece casi totalmente la rima ingeniosa característica del Dr. Seuss, sustituida por humor y aventuras, a excepción de la voz en off rimada de un narrador omniscente. La película mueve el tono a la acción. El estilo del original se traduce casi íntegramente al 3D, manteniendo las carac- 
terísticas más reconocibles de sus personajes.

En el último caso, "Ferdinand", sucede algo similar, convirtiendo la voz particular del álbum ilustrado en algo más genérico y entretenido para todos los públicos. El tema pacifista del libro se mantiene, pero el tono se centra una vez más en la acción, añadiendo personajes y tramas insexistentes en el original pero continuando el argumento principal. Este libro en particular ya había sido adaptado en el pasado por Disney en un cortometraje, pero esta versión aplica el 3D por primera vez, alejado de las ilustraciones originales.

\subsubsection{Tema diferente y tono semejante}

El tema diferente y tono semejante lo vemos claramente en "Shrek" (Adamson, Jenson, 2001), en el que permanece el humor intertextual, con la clara inteción de no tomarse muy en serio a sí mismo, pero el tema de la historia es totalmente distinto, manteniendo solo lo más básico del álbum, realizando una película mucho más compleja y centrada en transmitir un mensaje diferente alrededor de unos personajes más profundos y desarrollados. El estilo caricaturesco y suelto de las ilustraciones del álbum es transformado en un diseño realista 3D.

El tema diferente y tono semejante lo vemos también en "Meet the Robinsons" (Anderson, 2007) y en "Rise of the Guardians" (Ramsey, 2012), en los que además también cambia el protagonista.

En el primer caso se mantiene el humor disparatado y casual del original pero el tema es otro, introduciendo los viajes en el tiempo, que solo se mencionan en el álbum. Además el protagonista es alterado, ya no se trata del mejor amigo de Wilbur y el propio Wilbur como en el álbum, sino que pasa a ser mayormente Lewis, que pese a basar su diseño en el mejor amigo de Wilbur del original es un personaje totalmente diferente. La estética 3D del largometraje también trata de reflejar de alguna manera las elaboradas ilustraciones de Joyce (1990).

"Rise of the Guardians" al estar basado en una saga provoca que la historia y el tema recojan fragmentos de todos los libros, por lo que solo podemos decir que el tema y el protagonista no es similar al del libro ilustrado que se analiza en este trabajo. El tono mágico y esperanzador si que se mantiene en la película, siendo parte central del espíritu del largometraje, pese a centrarse mucho más en la acción. El diseño de personajes responde al del original, así como el colorido de la película.

Por lo que vemos en estos ejemplos los largometrajes presentan una tendencia a alterar el tono para convertirlo en uno más humorístico y centrado en la acción, muchas veces perdiendo el matiz irónico o poético del álbum o libro original.

El tema también cambia en los largometrajes para centrarse en argumentos 
solo sugeridos en el original, desarrollar más a los personajes y darles profundidad o para convertir la historia en algo lleno de acción y aventuras, que se traducen mucho mejor en la gran pantalla que a papel.

El protagonista cambia cuando lo que pretenden es dar un nuevo giro al argumento que no se plantea en el libro, por lo que reinventan un personaje o crean otro completamente nuevo.

En todos estos casos podemos observar que al dilatar el argumento existe una propensión a cambiar el tema o el tono para ajustarlo a el incremento de la acción y en ocasiones el humor. Muchas de estas películas también engrandecen o crean la figura del antagonista para provocar mayor conflicto con el protagonista. 


\section{CONCLUSIONES}

El mundo de las adaptaciones audiovisuales de libros o álbumes ilustrados infantiles es un campo de gran interés sobre el que no se ha investigado lo suficiente. Teniendo en cuenta el fervor que desatan las adaptaciones, especialmente si hablamos de las súperproducciones, no es de extrañar que la conclusión más evidente sea que como sociedad disfrutamos de la visualización de la misma historia a través de medios diferentes. Nos gusta volver a encontrarnos con esos personajes o esa trama que en un primer momento capturó nuestra atención, verlos transformados y reversionados en otro formato.

En el caso de las adaptaciones infantiles, los niños pueden comparar y entender la historia de otra manera, ayudando a formar su capacidad de crear relaciones intertextuales e intermodales, desplegando un posible potencial didáctico que los docentes pueden utilizar. Estas películas también apelan a otro receptor, los adultos, utilizando la nostalgia y el humor intertextual como manera de mantener la atención de este público.

Este trabajo se centra en analizar una serie de adaptaciones y sus originales para poder plantear una manera de clasificarlas. Tener en cuenta la continuidad del tono y el tema establece una división sencilla pero efectiva entre los distintos métodos para adaptar la obra. Así mismo tener en cuenta los cambios en el personaje principal ayuda a establecer las alteraciones que experimenta la historia original en su versión audiovisual. Como vemos, el hecho de que se trate de un largometraje, cortometraje o mediometraje es también muy influyente, así como si ha sido adaptado por un gran estudio o uno independiente, porque las expectativas serán diferentes.

De estos resultados podemos extraer la conclusión de que los largometrajes por lo general son los que más cambios experimentan con respecto a la obra original, mientras que los cortometrajes tienden a respetar más la fuente, muchas veces incluso manteniendo totalmente el estilo de las ilustraciones.

Las películas con mayor duración deben dilatar el argumento original o cambiarlo para adaptarse al tiempo. Por lo general, vemos una tendencia a utilizar la acción y el humor de forma más continuada en los largometrajes, ya que la atención del espectador infantil necesita de más estímulos visuales y auditivos para mantenerse durante tanto tiempo en la pantalla. Es por esto por lo que el tono y el tema pueden experimentar cambios, trasladando el libro o álbum al lenguaje audiovisual con diferentes niveles de correspodencia. Por ejemplo el tema y el tono pueden ser totalmente distintos al del original, como hemos visto que sucede con "Where the Wild Things Are" (Jonze, 2009), "The Ant Bully" (Davis, 2006), "Cloudy with a chance of meatballs" (Miller, Lord 2009) y "The boss baby" (McGrath, 2017), tratándose más de recreaciones que de adaptaciones.

Lo menos abundante vemos que es que el tono y el tema se mantengan en los largometrajes, además de la presencia del mismo protagonista que el libro. Ninguna de las películas de larga duración estudiadas en este trabajo cumple con la correspondencia de estas tres características, mientras que 
todos los cortometrajes lo cumplen fielmente.

Uno de los tipos de adaptaciones más interesantes es el que mantiene el mismo tono que el libro, como sucede con "Shrek" (Adamson, Jenson, 2001) y "Meet the Robinsons" (Anderson, 2007), pese al cambio radical en el argumento con respecto al original. Que se consiga trasladar la "voz" característica de la versión a papel a la pantalla aunque el tema no sea el mismo es un logro que nos habla de como se traducen las emociones que provoca una historia en lenguajes visuales diferentes. Pese a la alteración de los "ingredientes", el sabor es el mismo.

Ser conscientes de estas diferencias desarrolla nuestra visión crítica y estimula nuestra capacidad para crear interconexiones, ayudando así mismo a distinguir los factores que construyen una historia, todos aquellos mecanismos que la convierten en lo que es, única y la misma a un tiempo. 


\section{BIBLIOGRAFÍA}

AURIER, P. \& GUINTCHEVA, G., (2014). From book to movie: an investigation of adaptation and its impact on spectators' evaluation judgment. Post-Print hal-02084347, HAL. Recuperado de: https://ideas.repec.org/p/hal/journl/hal02084347.html

COHEN, D., MACKEITH, S., (1993). El desarrollo de la imaginación: Los mundos privados de la infancia. Paidós.

COLLINS A., HAND C. \& LINNEL M. (2008), Analyzing repeat consumption of identical cultural goods: some exploratory evidence from moviegoing. Journal of Cultural Economics, 32, 187- 199. doi: 10.1007/s10824-008-9072-0

DÍAZ ARMAS, J. (2005). Guerras de mentira: carnaval y parodia en Salvador Bartolozzi. En V. Ruzicka, C. Vázquez y L. Lorenzo (eds.), Mundos en conflicto: representación de ideologías, enfrenta- mientos sociales y guerras en la literatura infantil y juvenil pp. 581-601

HIDALGO RODRÍGUEZ, M.C., (2015). Multiculturalismo y exclusión social en álbumes ilustrados: Método de análisis. Universidad del Zulia. Opción, Año 31, No. Especial 4 pp. $581-601$

HIDALGO RODRÍGUEZ, M.C., (2013). Trends in drawing for children in Spain. The International Journal of Visual Design. Vol. 6. No 2: 17-31

KELLNER, D. \& SHARE, J., (2007). Critical media literacy is not an option Learning Inquiry, vol.1, pp.56-69. Recuperado de: https://doi.org/10.1007/ s11519-007-0004-2

KÜMMERLING-MEIBAUER, B. (2013). Introduction: New Perspectives in Children's Film Studies. Journal of Educational Media, Memory \& Society, 5(2), 39-44. Recuperado de: www.jstor.org/stable/43049663

LORENZO-GARCÍA, L., \& RODRÍGUEZ-RODRÍGUEZ, B. (2015). La intertextualidad en los textos audiovisuales: el caso de Donkey Xote. Ocnos, 13, 117-128. doi: 10.18239/ocnos_2015.13.07

MACKEN-HORARIK, M., UNSWORTH, L., \& LOVE, K. (2011-2013). Grammar and praxis: investigating a grammatics for 21st century school English. Australian research Council (arC)

MALLAN, K. \& BRADFORD, C., (2011). Contemporary Children's Literature and Film: Engaging with Theory. Palgrave Macmillan: Houndmills, Basingstoke, Hampshire; New York

MUSFAR, A., (2019). Exploring Visual Perception and Children's Interpretation in Children Literature and its Adaptations. Smart moves journal ijellh, [S.I.], v. 7, n. 9, p. 17. Recuperado de: https://ijellh.com/OJS/index.php/OJS/article/ view/9823 
NEIRA PIÑEIRO, M., FOMBELLA COTO, I., \& DEL MORAL PÉREZ, M. (2019). Potencialidad didáctico-creativa de un álbum ilustrado enriquecido con recursos digitales y realidad aumentada. Edmetic, 8(2), 108-128.

NIKOLAJEVA, M. y SCOTT, C. (2001). How Picturebooks Work. Nueva York y Londres : Garland Publishing.

RODRÍGUEZ PASCUAL, R., \& VARA LÓPEZ, A. (2019). La fantasía en el álbum ilustrado infantil. ÁLabe, 0(20). Recuperado de: http://dx.doi. org/10.15645/Alabe2019.20.5

OROZCO LÓPEZ, M. T. (2009). El libro álbum: definición y peculiaridades. Sincronía Fall. Recuperado de: http://sincronia.cucsh.udg.mx/orozcofall09.htm

OSPINA, G. (2010). La Pedagogía por Proyectos en los talleres de creación de libros álbumes. Imágenes de Investigación. Revista Infancias Imágenes Vol. 9 / No. 2 pp. 58-78.

O'SULLIVAN, E. (2005). Comparative Children's Literature. Routledge

ROSERO N., J., (2010). Las cinco relaciones dialógicas entre el texto y la imagen dentro del álbum ilustrado. Bogotá

RUSSELL, C.A. \& LEVY, S.J. (2012), The temporal and focal dynamics of volitional reconsumption: a phenomenological investigation of repeated hedonic experiences. Journal of Consumer Research, 39, 2, pp. 341-359.

SCHINDEL, M. (1981). Children's Literature on Film: Through the Audiovisual Era to the Age of Telecommunications. Children's Literature 9, 93-106. doi:10.1353/chl.0.0050.

SENÍS FERNÁNDEZ, J. (2004). El álbum ilustrado como agente de educación artístico literaria y de género. Zaragoza: Universidad de Zaragoza. Dossiers Feministes, pp. 115-133.

UNSWORTH, L. (2013). Re-configuring image-language relations and interpretive possibilities in picture books as animated movies: A site for developing multimodal literacy pedagogy. Ilha do Desterro: A Journal of English Language, Literatures in English and Cultural Studies, (64), 15-47. Recuperado de: https://www.redalyc.org/articulo.oa?id=4783/478348613002

UNSWORTH, L., (2013). Point of view in Picture books and animated movie adaptations. Scan: The Journal for Educators, Vol. 32, No. 1, pp. 2837. Recuperado de: https://search.informit.com.au/documentSummary;d$\mathrm{n}=581930455780575$;res $=$ IELHSS

WELSH, J. M. \& LEV, P. (2007), The Literature/Film reader: issues of adaptation. The Scarecrow press: Toronto 


\section{CURRICULUM}

Sara Martínez Maiso

Doble máster en Profesorado y Dibujo: Ilustración, Cómic y Creación Audiovisual

Dirección Postal: Jorge Vigón, 51, $2^{\circ}$ Izq, Logroño, La Rioja 26003

Dirección electrónica: saramaisor@hotmail.com

- Graduada con excelencia en estudios universitarios en la Facultad de Bellas Artes: Creación y Diseño en la UPV, Leioa, con especialización en Ilustración. Matrículas de honor en Dibujo dos años consecutivos. Calificación de 10 en el Trabajo de Fin de Grado: "Imaginario".

- Segundo año de estudios universitarios en Lengua y Literatura Hispánica por la UNED.

- Titulada en máster de Profesorado (MAES) especializado en Educaión Artística por la Universidad de Granada.

- Máster de Dibujo: Ilustración, Cómic y Creación Audiovisual en la Universidad de Granada.

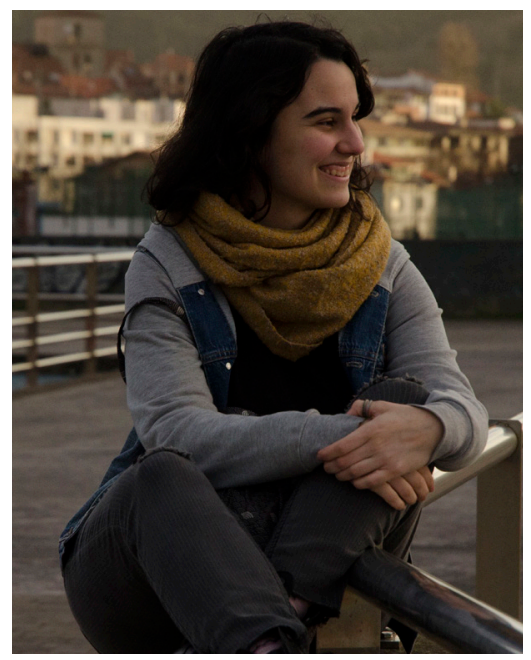

